\title{
Advancing Replicable Solutions for High-Performance Homes in the Southeast
}

S.G. Roberts, M.L. Sweet, and A. Francisco Partnership for Home Innovation 


\section{NOTICE}

This report was prepared as an account of work sponsored by an agency of the United States government. Neither the United States government nor any agency thereof, nor any of their employees, subcontractors, or affiliated partners makes any warranty, express or implied, or assumes any legal liability or responsibility for the accuracy, completeness, or usefulness of any information, apparatus, product, or process disclosed, or represents that its use would not infringe privately owned rights. Reference herein to any specific commercial product, process, or service by trade name, trademark, manufacturer, or otherwise does not necessarily constitute or imply its endorsement, recommendation, or favoring by the United States government or any agency thereof. The views and opinions of authors expressed herein do not necessarily state or reflect those of the United States government or any agency thereof.

Available electronically at SciTech Connect http:/www.osti.gov/scitech

Available for a processing fee to U.S. Department of Energy and its contractors, in paper, from:

U.S. Department of Energy

Office of Scientific and Technical Information

P.O. Box 62

Oak Ridge, TN 37831-0062

OSTI http://www.osti.gov

Phone: 865.576 .8401

Fax: 865.576.5728

Email: reports@osti.gov

Available for sale to the public, in paper, from:

U.S. Department of Commerce

National Technical Information Service

5301 Shawnee Road

Alexandria, VA 22312

NTIS http://www.ntis.gov

Phone: 800.553 .6847 or 703.605 .6000

Fax: 703.605.6900

Email: orders@ntis.gov 


\title{
Advancing Replicable Solutions for High-Performance Homes in the Southeast
}

\author{
Prepared for: \\ The National Renewable Energy Laboratory \\ On behalf of the U.S. Department of Energy's Building America Program \\ Office of Energy Efficiency and Renewable Energy \\ 15013 Denver West Parkway \\ Golden, CO 80401 \\ NREL Contract No. DE-AC36-08GO28308 \\ Prepared by: \\ S.G. Roberts, M.L. Sweet, and A. Francisco \\ Southface Energy Institute \\ As a part of the Home Innovations Research Lab's \\ Partnership for Home Innovation \\ 400 Prince George's Boulevard \\ Upper Marlboro, MD 20774 \\ NREL Technical Monitor: Stacey Rothgeb \\ Prepared under Subcontract No. KNDJ-0-40335-05
}

March 2016 
The work presented in this report does not represent performance of any product relative to regulated minimum efficiency requirements.

The laboratory and/or field sites used for this work are not certified rating test facilities. The conditions and methods under which products were characterized for this work differ from standard rating conditions, as described.

Because the methods and conditions differ, the reported results are not comparable to rated product performance and should only be used to estimate performance under the measured conditions. 


\section{Contents}

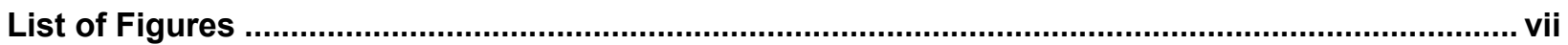

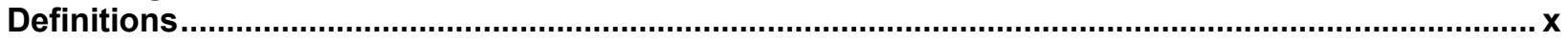

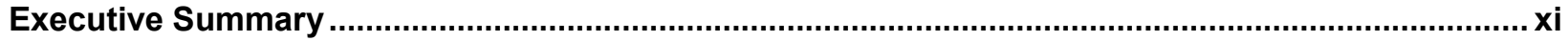

1 Introduction

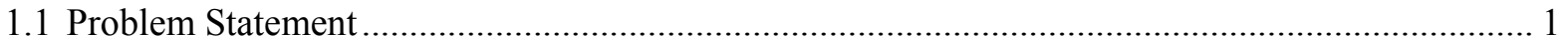

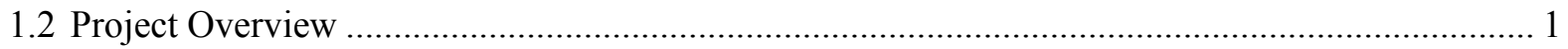

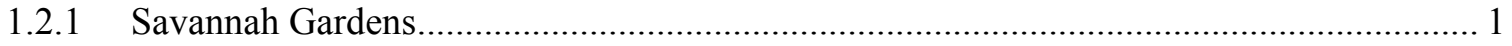

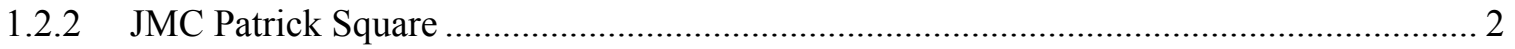

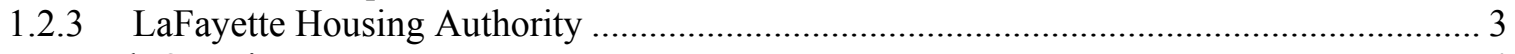

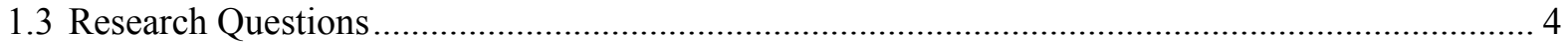

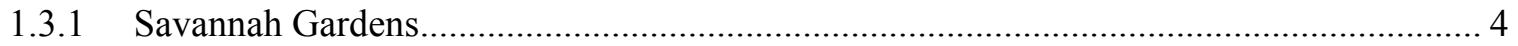

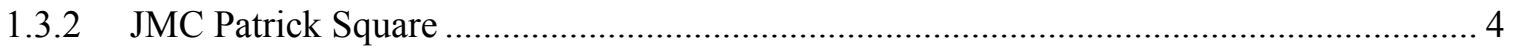

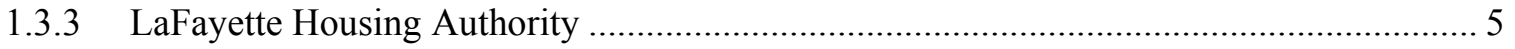

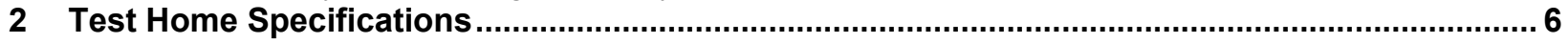

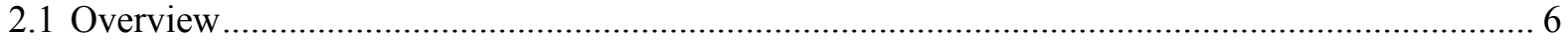

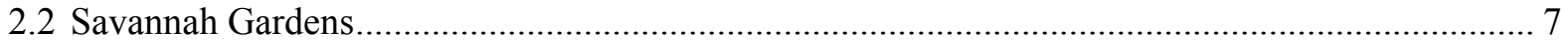

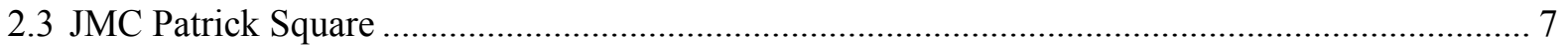

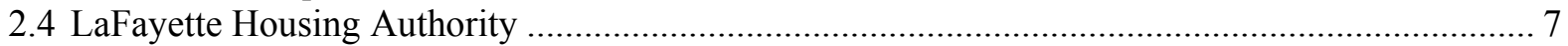

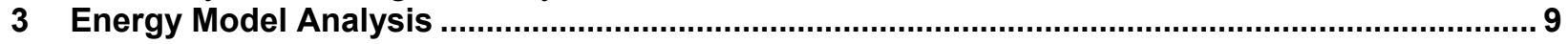

3.1 Improvements to Standard Home in Savannah Gardens............................................................. 9

3.1.1 Savannah Gardens REM/Rate Site Energy Analysis .................................................... 10

3.1.2 Savannah Gardens REM/Rate Total Cost of Ownership Analysis .................................. 11

3.2 JMC Patrick Square Builder Base Package Optimization .......................................................... 11

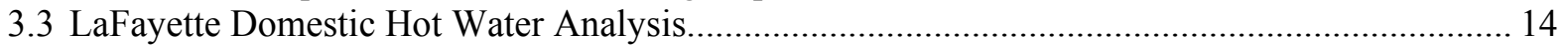

4 Construction and Quality Management Systems

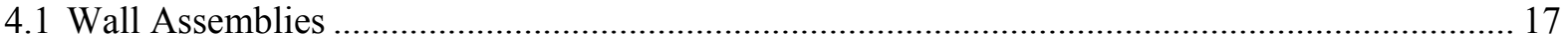

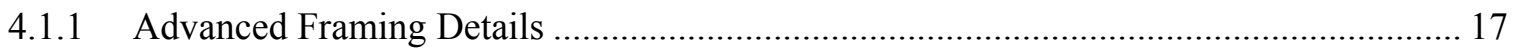

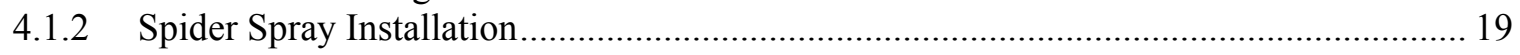

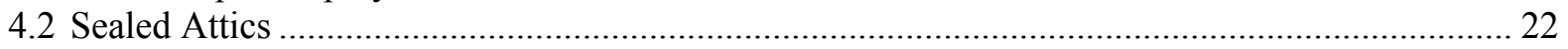

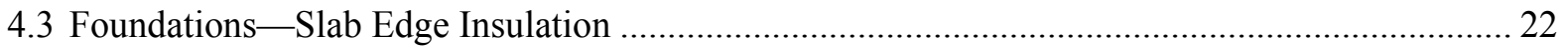

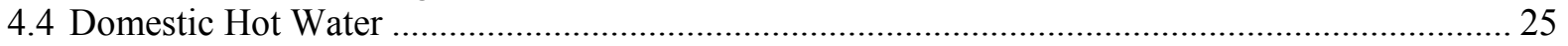

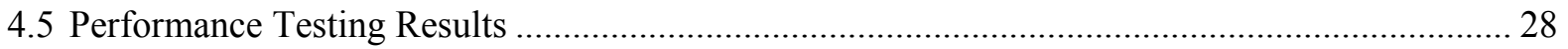

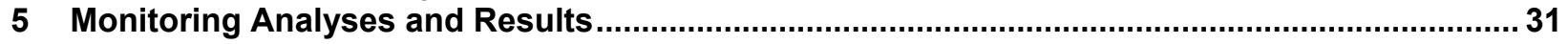

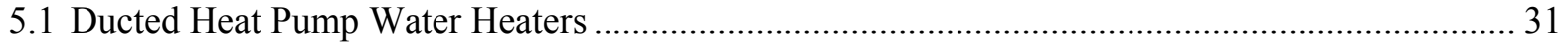

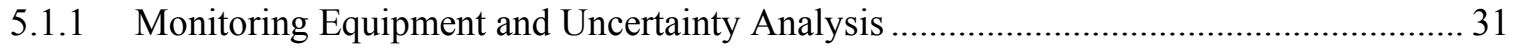

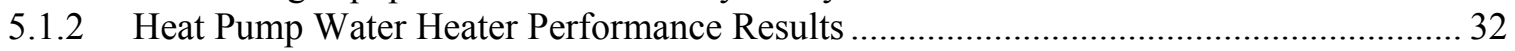

5.1.3 Impact on Encapsulated Attic Air Temperature and Humidity ……................................. 34

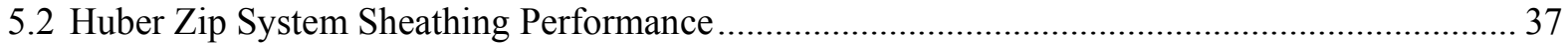

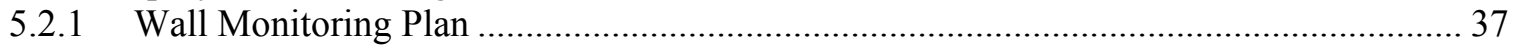

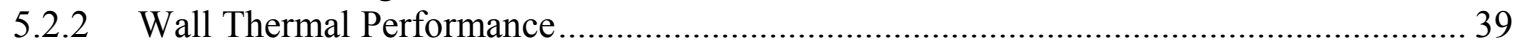

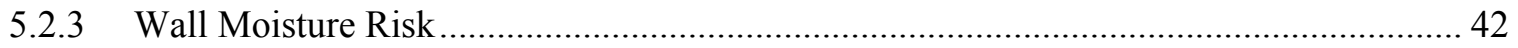

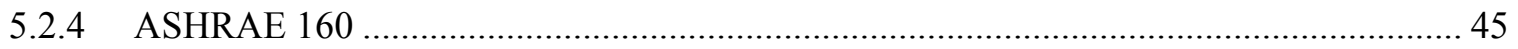

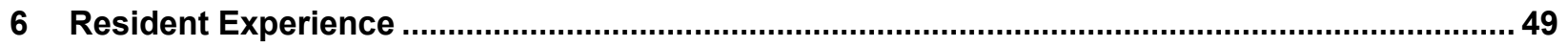

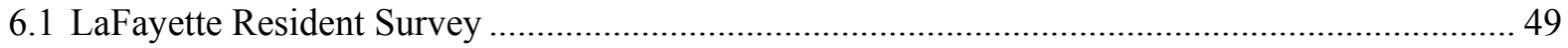

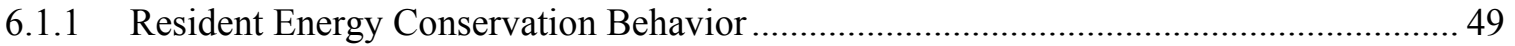

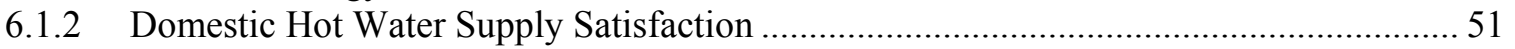

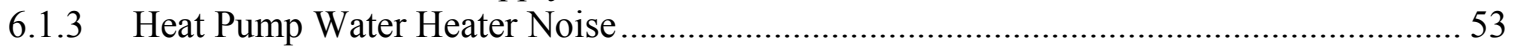

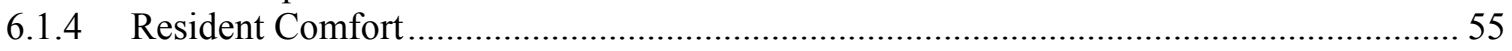

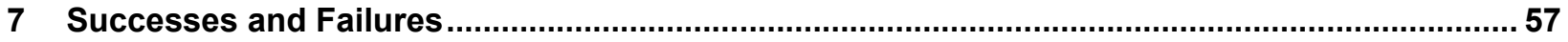




\section{u.s. DEPARTMENT OF | Energy Efficiency \& \\ ENERCY Renewable Energy}

7.1 Savannah Gardens

7.2 JMC Patrick Square

7.3 LaFayette

8 Conclusions

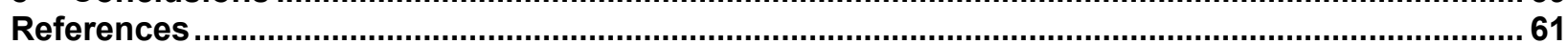




\section{List of Figures}

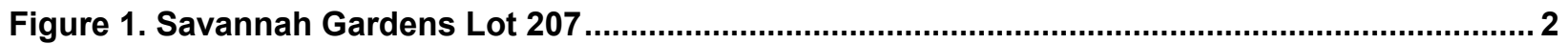

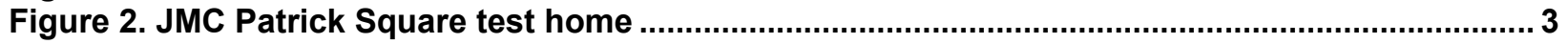

Figure 3. Typical LaFayette two-bedroom/three-bedroom duplex .................................................... 3

Figure 4. Savannah test home floor plan..................................................................................... 7

Figure 5. JMC test home floor plan $(8 \times 18$ porch was upgraded to a sunroom in as-built) ............... 8

Figure 6. Typical LaFayette two-bedroom/three-bedroom duplex floor plan; red circles indicate HPWH locations.

Figure 7. 39\% predicted site energy savings of as-built (HPWH ZipR) Savannah Gardens Lot 207

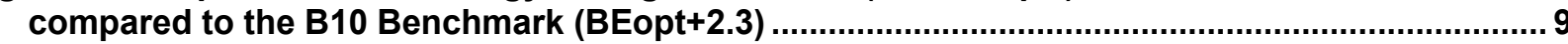

Figure 8. EPAct tax credit eligibility report generated by REM/Rate ................................................ 10

Figure 9. EPAct tax credit eligibility report generated by REM/Rate with exterior slab insulation .. 11

Figure 10. JMC BEopt model of the test home, View 1 ............................................................ 12

Figure 11. JMC builder package, proposed, and as-built BEopt comparison ................................... 14

Figure 12. BEoptE+2.3 energy model comparisons of as-built to B10 Benchmark for the two- and

three-bedroom LaFayette unit types predicts 31\% source energy savings for both................. 15

Figure 13. Front elevation of LaFayette duplex with the original plan to include a south-facing

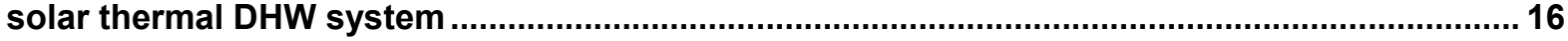

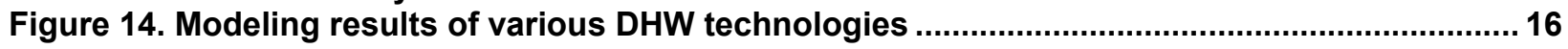

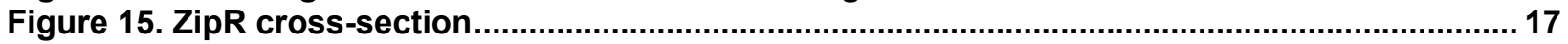

Figure 16. Framing details of two-stud corners from LaFayette construction drawings................. 18

Figure 17. Window head at gable details from construction drawings .............................................. 19

Figure 18. Installation of Johns Manville Spider insulation ........................................................ 20

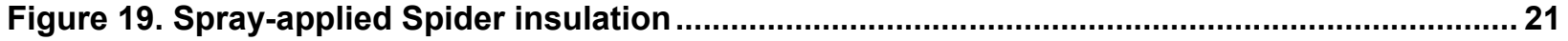

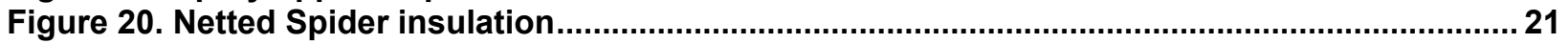

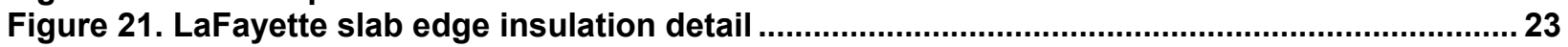

Figure 22. LaFayette slab edge insulation installed before the porch pour .................................. 24

Figure 23. JMC elevated slab construction in progress showing gap insulation and stem wall ..... 24

Figure 24. JMC thermal image facing exterior wall showing heat transfer through the slab ........... 25

Figure 25. Rendering of LaFayette HPWH critical dimensions ...................................................... 26

Figure 26. Vertical intake transfer duct connects to a vent in the mechanical closet's ceiling (left); horizontal exhaust duct connects to 3 -in. $\times 14$-in. rectangular duct inside the wall cavity leading to the HPWH in closet (right).

Figure 27. Savannah Gardens Lot 207 HPWH in the encapsulated attic before the exhaust duct was installed (left) and after the exhaust duct was installed (right) .......................................... 27

Figure 28. LaFayette airtightness values. Data Courtesy of SKCollaborative...................................29

Figure 29. Attic air leakage pathways identified in ocSPF at truss-to-top plate intersection............30

Figure 30. Attic air leakage pathways identified around master bathtub ......................................... 30

Figure 31. Scatter plot of daily hot water use versus COP for all five units .................................... 34

Figure 32. Savannah Unit $E$ and Unit $F$ absolute humidities at the high center locations of the attic and the living spaces

Figure 33. Attic temperatures at five locations around the attic during the summer at LaFayette

Site E. The circled area can be seen in zoom in Figure 34. ................................................... 36

Figure 34. Zoomed section of Figure 33 showing attic temperature changes during HPWH

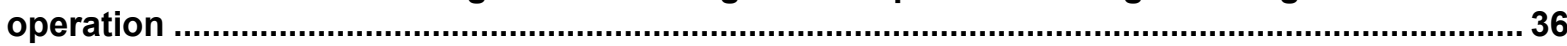

Figure 35. OmniSense sensor locations and positions in Zip and ZipR test homes........................ 37

Figure 36. OmniSense sensor position A in ZipR home (left); Zip home (right) ............................... 38

Figure 37. OmniSense sensor position C (left); position B (right) .................................................. 38

Figure 38. OmniSense sensor location and position in Zip (left); ZipR (right) walls ...................... 39

Figure 39. WNW wall temperatures on a cloudy (Sept. 2, 2014) and sunny (Sept. 3, 2014) day....... 40

Figure 40. ZipR and Zip NNE wall daily temperature profile............................................................. 41

Figure 41. Periods of potential condensation for Zip house on northeast wall. A yellow line at 20 indicates a risk of condensation.

Figure 42. Periods of potential condensation for ZipR house on northeast wall. A yellow line at 20 
indicates a risk of condensation.

Figure 43. Plot showing the duration a wall cavity was exposed to high humidity levels when the temperature at the sheathing was lower than the dew point

Figure 44. Zip NE wall 30 -day temperature and humidity running averages...................................... 46

Figure 45. Zip NE wall 30-day temperature and humidity running averages.....................................46

Figure 46. Zip NNE sheathing hourly temperature and humidity ...................................................47

Figure 47. ZipR NNE sheathing hourly temperature and humidity............................................... 48

Figure 48. At what temperature water do you wash your clothes? (Please check all that apply.)... 49

Figure 49. What is the typical duration of a shower in your household (minutes)? ........................ 49

Figure 50. In general, what temperature (in degrees) is your thermostat set to during the winter?

Figure 51. In general, what temperature (in degrees) is your thermostat set to during the summer? 50

Figure 52. Have you utilized your thermostat's ability to automatically adjust temperature settings throughout the day?

Figure 53. How would you rate the cost of your electric bills? ..................................................51

Figure 54. Do you avoid taking consecutive showers to prevent running out of hot water?.......... 52

Figure 55. How often, if ever, do you experience shortage of hot water while showering/bathing?

Figure 56. How often, if ever, do you experience a shortage of hot water while using the kitchen sink?

Figure 57. I am satisfied with the supply of hot water in my home.

Figure 58. Do you hear noise from the mechanical equipment behind the locked doors in your home?

Figure 59. How often do you hear the operation of mechanical equipment behind the locked doors in your home?

Figure 60. Does the noise disturb your daily activities? If yes, please explain. 54

Figure 61. My home feels comfortable during every season: (winter, spring, summer, and fall)....55

Figure 62. I am satisfied with the overall comfort of my home. ...................................................56

Figure 63. All rooms in my home are equally comfortable................................................................ 56

Figure 64. Do you experience issues with the indoor air quality (pollen, allergens, odors, etc.)? .. 56

Unless otherwise noted, all figures were created by the Partnership for Home Innovation team. 


\section{List of Tables}

Table 1. Heating and Cooling Degree Days (Base $65^{\circ} \mathrm{F}$ ) of the Three Project Sites ${ }^{\mathrm{a}} \ldots \ldots \ldots \ldots \ldots \ldots \ldots . . . . . . . . . . .1$

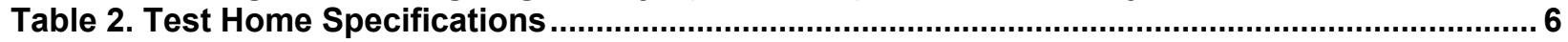

Table 3. JMC Patrick Square Proposed Base Package Upgrades and the As-Built

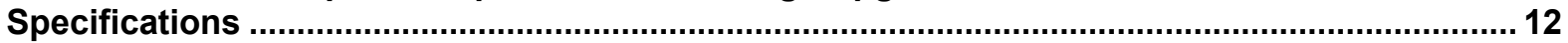

Table 4. LaFayette Water Heating Analysis Revealed HPWH Provided the Best Value .................... 16

Table 5. Test Home Wall Assemblies ....................................................................................... 17

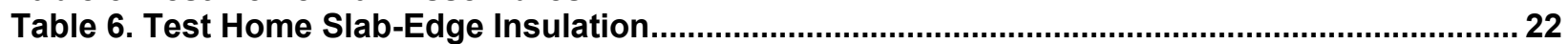

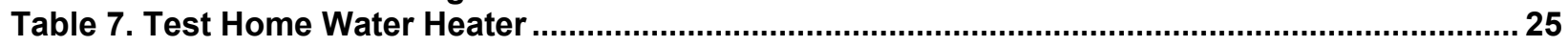

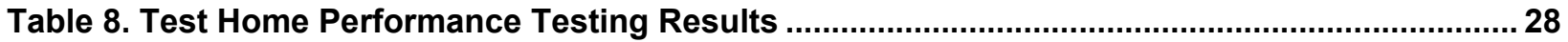

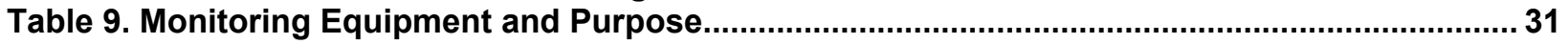

Table 10. Uncertainty for Example Daily Values ............................................................................. 32

Table 11. Summary of All Monitored HPWH Daily Average Variables Used To Compute Daily

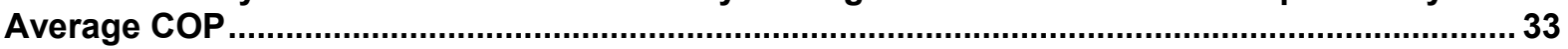

Table 12. Date Ranges of Each Site and the Duct Configuration Applied ...................................... 34

Table 13. ZipR and Zip WNW Wall Sheathing (Position A) Average Temperature Summaries for

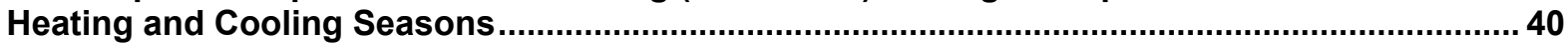

Table 14. Clear-Wall R-Value Comparison for Zip and ZipR Homes................................................ 42

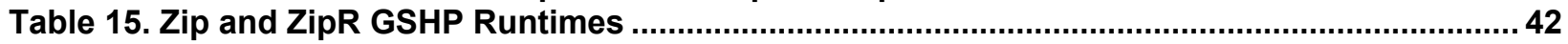

Table 16. Hours of Condensation Risk for All Sensor Locations during 300 Days of Monitoring ... 44

Table 17. Duration of Condensation Risk Events at Sheathing in NE Walls ..................................... 45

Unless otherwise noted, all tables were created by the Partnership for Home Innovation team. 


\section{Definitions}

$\mathrm{ACH}_{50}$

ASHRAE

BEopt ${ }^{\mathrm{TM}}$

Btu

$\mathrm{CFM}_{25}$

$\mathrm{CFM}_{50}$

COP

$\mathrm{CZ}$

DHW

DOE

EER

EF

EPAct

GSHP

HERS

HPWH

HVAC

$\mathrm{kWh}$

LHA

ocSPF

Zip

ZipR
Air Changes per Hour at 50 Pascals, Infiltration Measurement

American Society of Heating, Refrigerating and Air-Conditioning Engineers, Inc.

Building Energy Optimization Software

British Thermal Unit, Unit of Energy

Air Flow (CFM) at 25 Pascals, Duct Leakage Measurement

Air Flow (CFM) at 50 Pascals, Infiltration Measurement

Coefficient of Performance

Climate Zone

Domestic Hot Water

U.S. Department of Energy

Energy Efficiency Ratio

Efficiency Factor (domestic hot water efficiency)

Energy Policy Act of 2005

Ground-Source Heat Pump

Home Energy Rating System

Heat Pump Water Heater

Heating, Ventilating, and Air Conditioning

Kilowatt-Hour, Power Measurement

LaFayette Housing Authority

Open-Cell Spray Polyurethane Foam

ZIP Uninsulated Sheating

ZIP System R Sheathing 


\section{Executive Summary}

The work presented in this report advances the goals of the U.S. Department of Energy Building America program by improving the energy performance of affordable and market-rate housing. Southface Energy Institute (Southface), part of the U.S. Department of Energy Building America research team Partnership for Home Innovation, worked with owners and builders with various market constraints and ultimate goals for three projects in three climate zones (CZs): Savannah Gardens in Savannah, Georgia (CZ 2); JMC Patrick Square in Clemson, South Carolina (CZ 3); and LaFayette in LaFayette, Georgia (CZ 4). This report documents the design process, computational energy modeling, construction, envelope performance metrics, long-term monitoring results, and successes and failures of the design and execution of these highperformance homes.

The Savannah Housing Department sought energy-efficiency improvements to its standard single-family home plans in the Savannah Gardens Community. The three-bedroom/twobathroom test home is approximately $1,200 \mathrm{ft}^{2}$ on an elevated slab foundation and has a semiconditioned, encapsulated attic. A neighboring home built to standard EarthCraft specifications was also monitored as a control for certain measures, namely exterior foam insulation and a heat pump water heater (HPWH). Analysis predicted a net positive annual cash flow of $\$ 45$ for the owner.

The JMC Patrick Square project is a single floor with $1,828 \mathrm{ft}^{2}$ of conditioned living space, three bedrooms, two bathrooms, and an attached two-car garage. This small-scale production builder wanted to increase its level of energy efficiency beyond its current green building practices, including bringing ducts into conditioned space. The team met this goal through a combination of upgrade measures and achieved many Zero Energy Ready Home program requirements.

LaFayette Housing Authority partnered with Lord Aeck Sargent architects and Southface to design and construct a development of 30 affordable rental housing units in 15 duplexes in LaFayette, Georgia. The goal for these homes was to have low energy bills and be lowmaintenance, durable buildings because they are intended as long-term rentals. The team used Building Energy Optimization software to optimize building envelope and systems choices, including $2 \times 6$ advanced framed walls, an insulated slab, and an HPWH in a utility closet that was ducted to and from an encapsulated attic.

Monitoring the four ducted HPWHs in LaFayette and one in Savannah revealed that HPWH exhaust air impacts attic air during HPWH runtime only, and attic conditions return to previous levels shortly after the HPWH turns off. The HPWH did not appear to impact the loads on the heating and cooling systems, which were also placed in the attic. HPWHs should not be considered dehumidifiers if one is needed in an attic or basement/crawlspace.

Ducting the HPWHs did not negatively impact performance compared to other published data of field performace. Changing duct configurations also did not alter the coefficient of performance. HPWHs in efficiency mode (heat pump only) could satisfy hot water demand for most residents. This mode maximizes energy efficiency. 
Adding $1 / 2$ in. of insulated sheathing using the Huber ZIP System R Sheathing reduced peak summer temperatures and increased minimum winter temperatures inside the wall assemblies compared to the neighboring home. The neighboring home experienced significantly more risk of condensation and failed the American Society of Heating, Refrigerating and Air-Conditioning Engineers, Inc., Standard 160-2009: Criteria for Moisture-Control Design Analysis in Buildings. Despite the fact that energy modeling predicted only a $\%$ annual savings from the insulated sheathing, preliminary data indicate that reduced heating, ventilating, and air-conditioning runtimes and energy consumption attributed to this measure provide significantly greater savings. Additional research is necessary. 


\section{Introduction}

\subsection{Problem Statement}

This report documents the design process, computational energy modeling, construction, envelope performance metrics, and long-term monitoring results of three high-performance homes in three southeastern climate zones (CZs): Savannah Gardens in Savannah, Georgia (CZ 2); JMC Patrick Square in Clemson, South Carolina (CZ 3); and LaFayette in LaFayette, Georgia (CZ 4). Southface Energy Institute (Southface), part of the U.S. Department of Energy (DOE) Building America research team Partnership for Home Innovation, worked with owners and builders with different market constraints and ultimate goals for each project. Southface's partnerships in Savannah Gardens and LaFayette were with the local municipality's housing authority; the partnership for JMC Patrick Square was with a small-scale production builder. The housing authorities' key driver was to provide comfortable housing with low utility bills to people who qualified for affordable housing; however, one project was rental and the other owner-occupied. The production builder's key driver was to maximize market value with efficiency improvements that fit within its construction practices. Heating and cooling degree days for each location are listed in Table 1.

Table 1. Heating and Cooling Degree Days (Base $65^{\circ} \mathrm{F}$ ) of the Three Project Sites ${ }^{\mathrm{a}}$

\begin{tabular}{c|c|c|c}
\hline Location & CZ & Heating Degree Days & Cooling Degree Days \\
\hline Savannah, GA & 2 & 1,985 & 2,644 \\
Clemson, SC & 3 & 2,770 & 2,193 \\
LaFayette, GA & 4 & 3,415 & 2,042 \\
\hline
\end{tabular}

${ }^{\text {a }}$ Degree-day calculations are the average of the last 5 years. Historical data was obtained from the nearest data collection site and are archived in the National Climatic Data Center database.

\subsection{Project Overview}

\subsubsection{Savannah Gardens}

Southface partnered with the Savannah Housing Department to specify and construct a singlefamily, new-construction, test home in Savannah, Georgia (Figure 2). The department's goal was to redevelop a poverty-stricken community with sustainable homes at affordable prices for income-qualified buyers. The home is in the Savannah Gardens community, a 44-acre site that was redeveloped to meet the standards of the EarthCraft Communities program (Community Housing Services Agency, Inc. 2012). ${ }^{1}$ This community is part of a large neighborhood redevelopment effort and will include more than 500 housing units (120 of which are single family) upon completion. The site's master plan includes 5 acres of green space, and all homes are required to earn EarthCraft certification. The three-bedroom/two-bathroom test home is approximately $1,200 \mathrm{ft}^{2}$ of conditioned floor space on an elevated slab foundation and has a semi-conditioned, encapsulated attic. Like all homes in the community, this home is all electric, and no natural gas service is available. Although Southface partnered with Savannah Housing Department and Chatham Home Builders on the construction of Lot 207, a neighboring home built to standard EarthCraft specifications was also monitored as a control to compare certain measures, namely exterior foam insulation and a heat pump water heater (HPWH). Construction was completed in 2013.

\footnotetext{
${ }^{1}$ See www.earthcraft.org/builders/programs/earthcraft-communities/.
} 


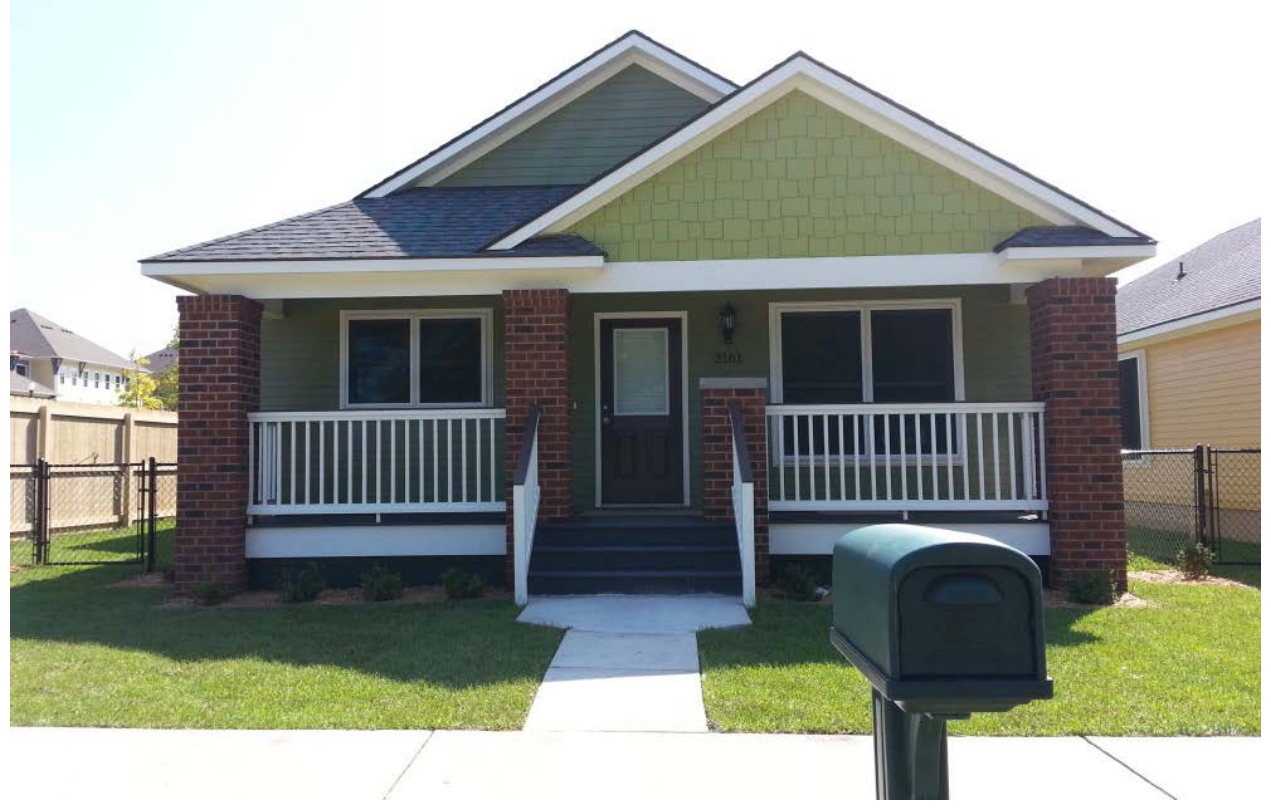

Figure 1. Savannah Gardens Lot 207

\subsubsection{JMC Patrick Square}

A small-scale production builder partnered with Southface to design and construct a new construction test house in Clemson, South Carolina, in the mixed-humid climate (CZ 3) (Figure 2). As a homebuilder that also participates in Southface's regional high-performance/green building program, EarthCraft Communities, the builder sought a cost-effective approach to reaching even higher levels of energy savings and home-buyer value. The team also set a goal to achieve DOE Challenge Home/Zero Energy Ready Home certification and the Energy Policy Act of 2005 (EPAct) tax credit (which expired at the end of 2014). The plan chosen for the prototype home includes a single floor with $1,828 \mathrm{ft}^{2}$ of conditioned living space, three bedrooms, two bathrooms, and an attached two-car garage. The team restricted its options to measures that could be replicated to future construction, including various plan layouts and foundation types. The perceived ability to sell the improvement cost to homebuyers was a key driver in selecting the final measure package. Foundation and attic construction was designed to place the heating, ventilating, and air-conditioning (HVAC) air handling unit and ducts into the conditioned space and achieve cost-effective elevations and storm water control on this lot. The builder chose a semi-conditioned, encapsulated attic and elevated slab foundation. Construction was completed in January 2015. 


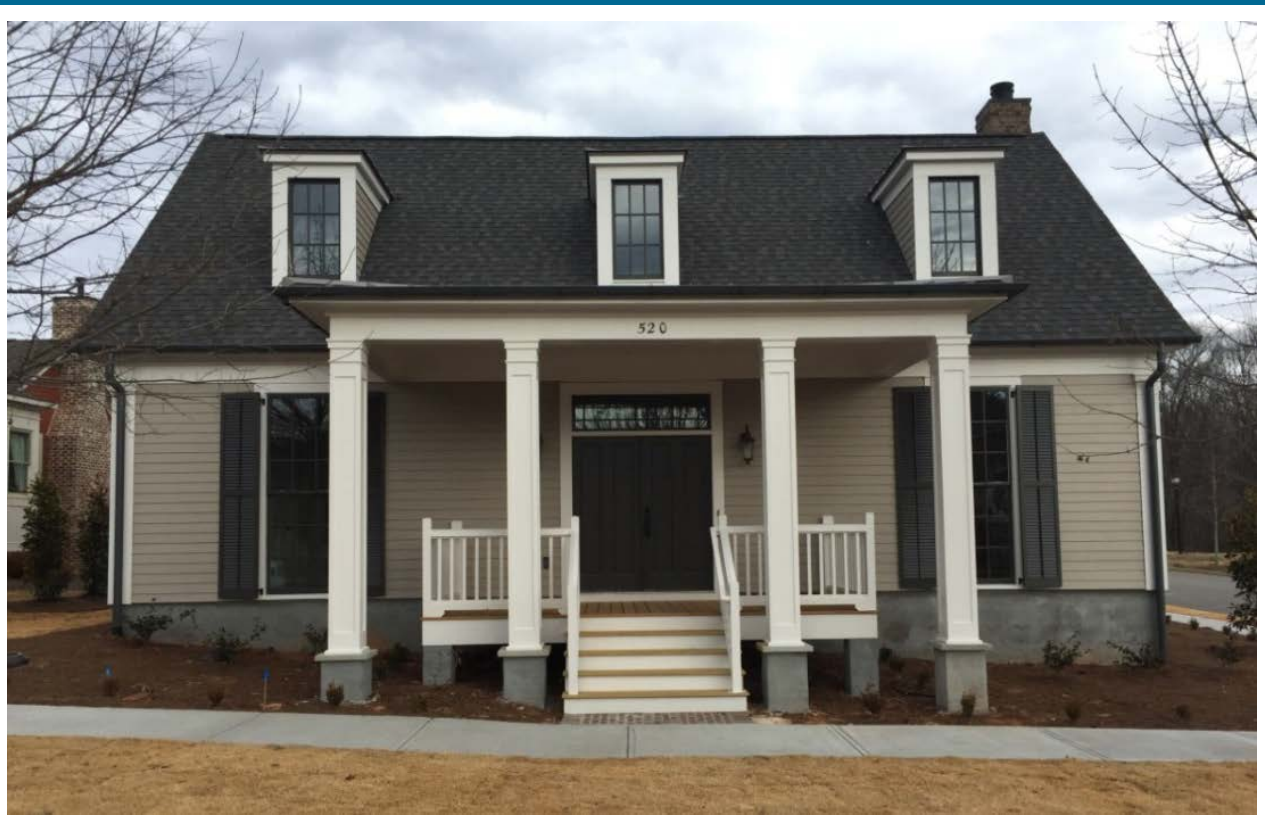

Figure 2. JMC Patrick Square test home

\subsubsection{LaFayette Housing Authority}

Southface partnered with the LaFayette Housing Authority (LHA) and architecture firm Lord Aeck Sargent to design, construct, and test 30 sustainable and affordable housing units in 15 duplexes (Figure 4). Each one-story duplex comprises a two-bedroom and a three-bedroom unit. LaFayette, Georgia, is situated in the northwestern corner of the state, approximately 30 miles due south of Chattanooga, Tennessee (CZ 4). Client goals were to minimize occupant utility bills and increase property durability and maintainability. This project, which is seeking Leadership in Energy \& Environmental Design for Homes Gold certification, was intended to be a replicable example for rural housing authorities that follow the design-bid-build procurement process that is typical of public housing initiatives.

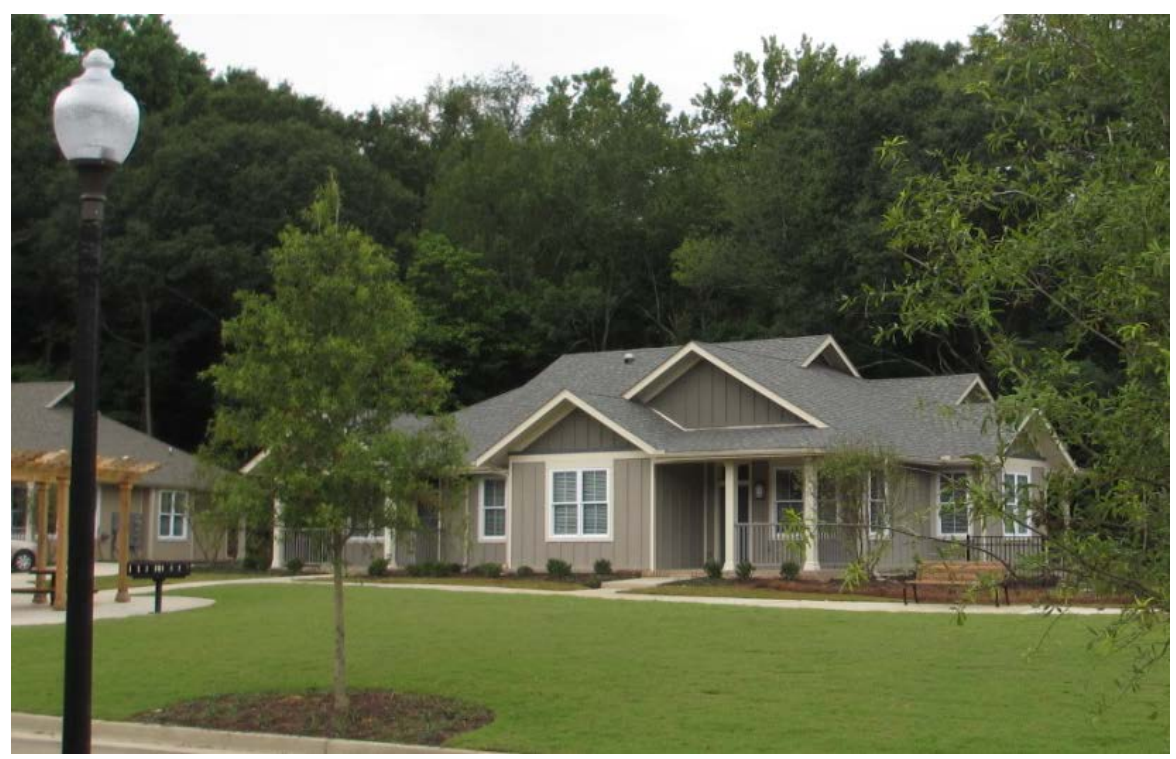

Figure 3. Typical LaFayette two-bedroom/three-bedroom duplex 


\subsection{Research Questions}

The research goals for all test homes included developing replicable energy-efficiency solution packages that meet Building America savings goals of 30\% compared to the 2009 International Energy Conservation Code. Each project also had individual marketing, construction, maintenance, or technology goals and questions.

\subsubsection{Savannah Gardens}

The Lot 207 test home was constructed with Huber's ZIP System R-Sheathing (ZipR) ( $1 / 2$ in. of rigid foam) in the vertical walls of the building envelope and was equipped with an A.O. Smith Voltex HPWH placed in an open-cell spray polyurethane foam (ocSPF) sealed attic. Southface's long-term research interests in this project were to analyze the performance of these two unique features during the course of a year and expand the knowledge of actual field performance of these emerging technologies. Temperature, humidity, and wood moisture content inside the wall assemblies and attic temperatures and humidities were monitored in the test home and a similarly built neighboring home. The neighboring home provided a baseline: it has approximately the same dimensions but has an electric resistance storage water heater in the attic and is clad with traditional ZIP System (Zip) sheathing without the rigid foam. The data will also provide a reference point for future computational models. The report answers the following questions:

- What is the average daily coefficient of performance (COP) of the HPWH as a function of daily hot water use and real-world variations in use patterns?

- What is the ability of the HPWH to keep up with hot water demand, and do occupants change the operating mode or temperature set point to ensure that they have enough hot water? Determine the amount and any patterns of auxiliary electric heat supplied.

- What effect does HPWH exhaust air have on temperature and relative humidity conditions in the attic space, and is there an effect on HVAC system performance, which is also in the encapsulated attic?

- What is the impact of different ducting configurations on HPWH COP?

- How much does the insulated sheathing affect the cavity temperature and moisture content of the exterior walls?

- What is the performance difference of both wall systems under extreme weather conditions and the impact on their resilience?

\subsubsection{JMC Patrick Square}

The research goals for the JMC test home included developing a market-ready, energy-efficiency solution package that does the following:

- Meets Building America savings goals

- Assesses cost/performance trade-offs that improve overall system performance and value

- Minimizes increased cost and includes consideration of occupant comfort, health, and safety. Because this builder was already building homes within a high-performance/green building program, particular attention was given to identifying gaps or improvements necessary to meet DOE Challenge Home/Zero Energy Ready Home program requirements. 
Evaluation of success includes:

- Calculating estimated energy savings

- Evaluating overall costs

- Identifying systems integration opportunities

- Identifying quality assurance and quality control lessons learned.

No long-term monitoring was conducted at this site, and the research questions focus on the design and bridging the gaps necessary to bring the builder's standard construction to DOE Challenge Home/Zero Energy Ready Home program specifications:

- What are the gaps between the builder's standard package and DOE Challenge Home/Zero Energy Ready Home program specifications?

\subsubsection{LaFayette Housing Authority}

The research focus for the LaFayette project was the performance of the HPWH installed with various ducting configurations. It also clarified the potential space-conditioning impacts of an HPWH that draws air from and exhausts air to an ocSPF encapsulated attic. Four HPWH units were monitored. Southface monitored HPWH power consumption, temperature, and relative humidity conditions in the attic and mechanical closet; inlet and exit water temperatures; and domestic hot water (DHW) flow rates. Southface and LHA administered a resident survey. The following questions are addressed:

- What is the average daily COP as a function of daily hot water use, and what are the realworld variations in use patterns?

- How well does the HPWH keep up with hot water demand, and do occupants report challenges in meeting hot water demand?

- What effect did water heater exhaust air have on temperature and relative humidity conditions in the attic space and mechanical closet?

- How well did residents accept this emerging technology as installed?

- What was the self-reported resident comfort and interaction with the energy conservation measures?

This research also provides real-world hot water draw profiles associated with low-flow fixtures. 


\section{Test Home Specifications}

\subsection{Overview}

Southface worked with each team of builder and designer/architects to specify energy-efficiency solution packages that achieved Building America and builder/owner's energy-efficiency goals, as well as constructability and marketing goals. The as-built specifications are listed in Table 2 .

Table 2. Test Home Specifications

\begin{tabular}{|c|c|c|c|}
\hline Measure & Savannah & JMC & LaFayette \\
\hline Foundation & Elevated slab & Elevated slab & Slab on grade \\
\hline $\begin{array}{l}\text { Foundation } \\
\text { Insulation }\end{array}$ & Uninsulated & Uninsulated & R-5 perimeter \\
\hline $\begin{array}{c}\text { Wall } \\
\text { Construction }\end{array}$ & $2 \times 4,16$ in. o.c. & $2 \times 4,16$ in. o.c. & $\begin{array}{l}2 \times 6,24 \text { in. o.c., } \\
\text { advanced framing }\end{array}$ \\
\hline Wall Insulation & $\begin{array}{l}\text { R-13 fiberglass batts, } \\
\text { grade I; R-3.6 insulated } \\
\text { exterior sheathing }\end{array}$ & Grade I, R-13 cellulose & $\begin{array}{l}\text { Grade I, R-22 blown-in } \\
\text { fiberglass }\end{array}$ \\
\hline $\begin{array}{c}\text { Ceiling } \\
\text { Construction }\end{array}$ & Encapsulated attic & Encapsulated attic & Encapsulated attic \\
\hline $\begin{array}{l}\text { Ceiling } \\
\text { Insulation }\end{array}$ & $\mathrm{R}-20$ ocSPF & $\mathrm{R}-20$ ocSPF & $\mathrm{R}-20$ ocSPF \\
\hline $\begin{array}{l}\text { Window } \\
\text { Ratings }\end{array}$ & $\mathrm{U} 0.34, \mathrm{SHGC}^{\mathrm{a}} 0.26$ & U 0.33, SHGC 0.24 & U 0.35, SHGC 0.31 \\
\hline Infiltration & $1.88 \mathrm{ACH}_{50}$ & $2.5 \mathrm{ACH}_{50}$ & $2.1 \mathrm{ACH}_{50}{ }^{\mathrm{b}}$ \\
\hline $\begin{array}{l}\text { Heating } \\
\text { Efficiency }\end{array}$ & $3.7 \mathrm{COP}$ & Gas $92.5 \%$ AFUE $^{c}$ & $8 \mathrm{HSPF}^{\mathrm{d}}$ \\
\hline $\begin{array}{l}\text { Cooling } \\
\text { Efficiency }\end{array}$ & 18.6 EER & $\begin{array}{l}16 \text { SEER; }{ }^{\mathrm{e}} 1 \text { stage } \\
\text { compressor }\end{array}$ & 14 SEER \\
\hline $\begin{array}{l}\text { Supply Duct } \\
\text { Location }\end{array}$ & Encapsulated attic & Encapsulated attic & Encapsulated attic \\
\hline $\begin{array}{l}\text { Return Duct } \\
\text { Location }\end{array}$ & Encapsulated attic & Encapsulated attic & Encapsulated attic \\
\hline Duct Leakage & $\begin{array}{l}\text { R-8 flex insulation, } 0 \% \text { to } \\
\text { outside }\end{array}$ & $\begin{array}{l}\text { R-10 insulation, } 0 \% \text { to } \\
\text { outside }\end{array}$ & $\begin{array}{l}\text { R-6 flex insulation, } 0 \% \\
\text { to outside }\end{array}$ \\
\hline Ventilation & Balanced; 40 cfm & Supply only & Supply only \\
\hline $\begin{array}{l}\text { Hot Water } \\
\text { Efficiency }\end{array}$ & $\begin{array}{c}\text { HPWH, } 2.33 \text { efficiency } \\
\text { factor (EF), R-2 Trunk } \\
\text { Branch PEX }\end{array}$ & $\begin{array}{c}\text { ENERGY STAR }{ }^{\circledR} \text { tankless; } \\
\text { 0.82 EF gas, R-2 Trunk } \\
\text { Branch cross-linked } \\
\text { polyurethane }\end{array}$ & $\begin{array}{l}\text { HPWH, } 2.33 \text { EF, R-2 } \\
\text { Trunk Branch cross- } \\
\text { linked polyurethane }\end{array}$ \\
\hline Lighting & $\begin{array}{l}90 \% \text { compact fluorescent } \\
\text { lamps, } 10 \% \text { linear } \\
\text { fluorescent lamps }\end{array}$ & $\begin{array}{l}90 \% \text { incandescent; } 10 \% \\
\text { compact fluorescent lamps }\end{array}$ & $80 \%$ fluorescent \\
\hline Appliances & ENERGY STAR & $\begin{array}{c}\text { Gas range; ENERGY } \\
\text { STAR dishwasher } 260 \mathrm{kWh}\end{array}$ & ENERGY STAR \\
\hline
\end{tabular}




\subsection{Savannah Gardens}

The Savannah Garden New Construction Test House was built within a community that uses a preapproved set of construction plans. The team therefore worked within the chosen plan to upgrade specifications on the given lot to meet project goals (Figure 4). The two significant upgrades were to include Huber's ZipR ( $1 \frac{1}{2}$ in. of rigid foam) and an A.O. Smith Voltex (PHPT60) HPWH in the attic.

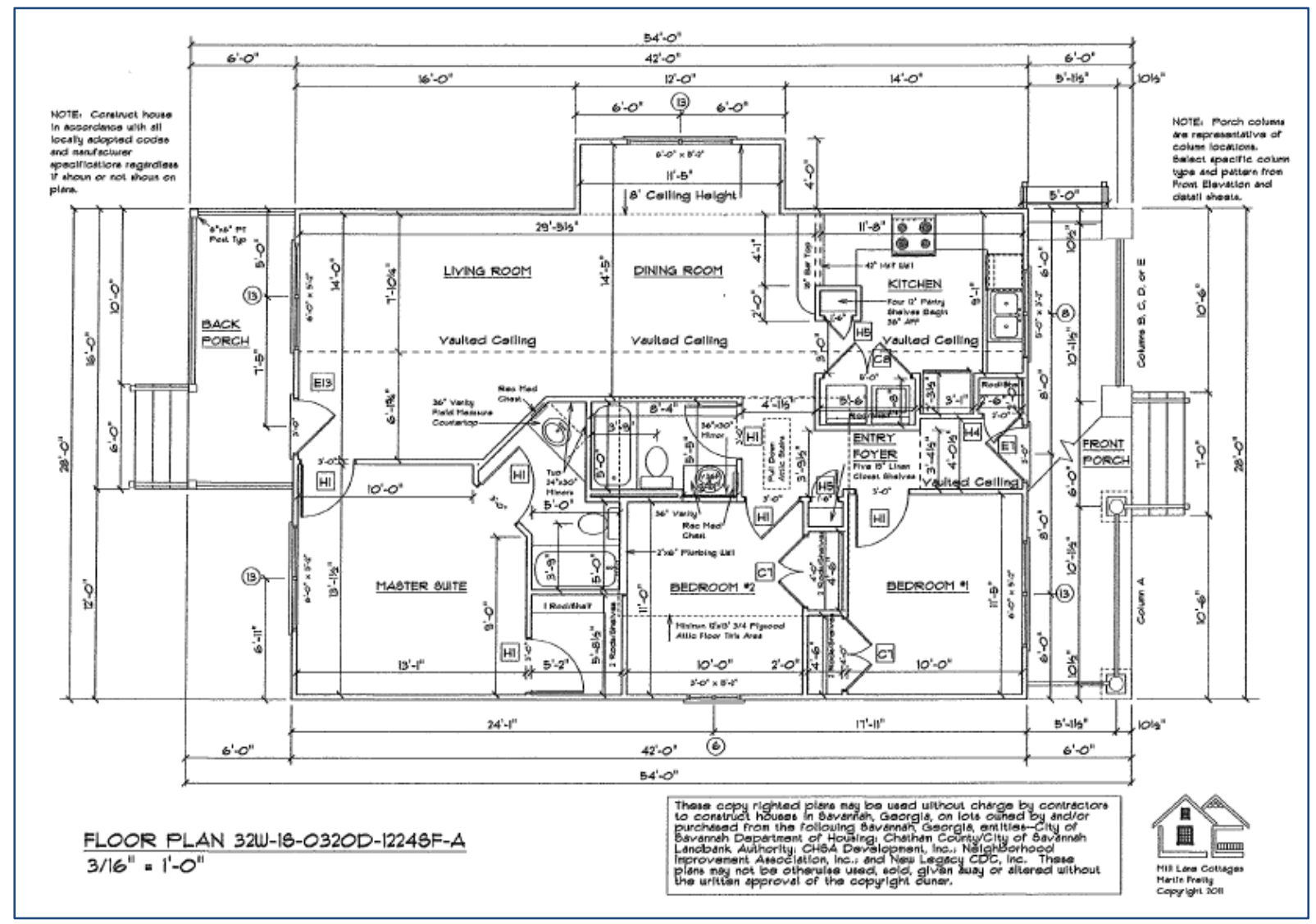

Figure 4. Savannah test home floor plan

\subsection{JMC Patrick Square}

JMC chose the York Cottage for the prototype home on a prominent corner lot. This plan includes a single floor with elevated slab foundation, $1,828 \mathrm{ft}^{2}$ of conditioned living space, three bedrooms, two bathrooms, an unfinished attic, and an attached, two-car garage. Figure 5 represents JMC's York Cottage base model. The New Construction Test House was upgraded with a sunroom and a tankless gas water heater that replaced the tank shown in the garage.

\subsection{LaFayette Housing Authority}

Lord Aeck Sargent designed 29 identical duplexes and 1 ADA-compliant duplex that were built on two sites (Figure 6). Each duplex consists of a two-bedroom and a three-bedroom unit. Note the location of the ducted HPWH in each unit inside a utility closet with a solid door. 


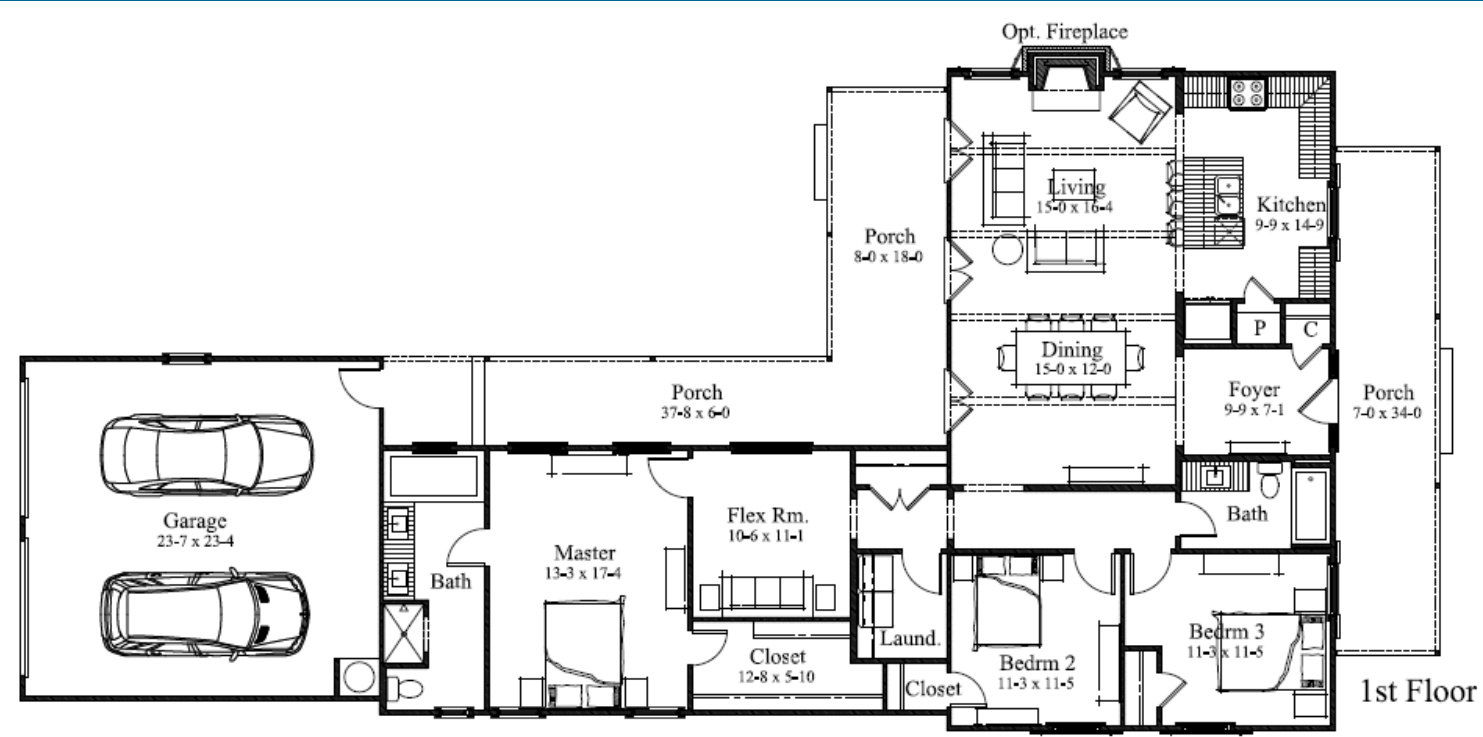

Figure 5. JMC test home floor plan $(8 \times 18$ porch was upgraded to a sunroom in as-built $)$

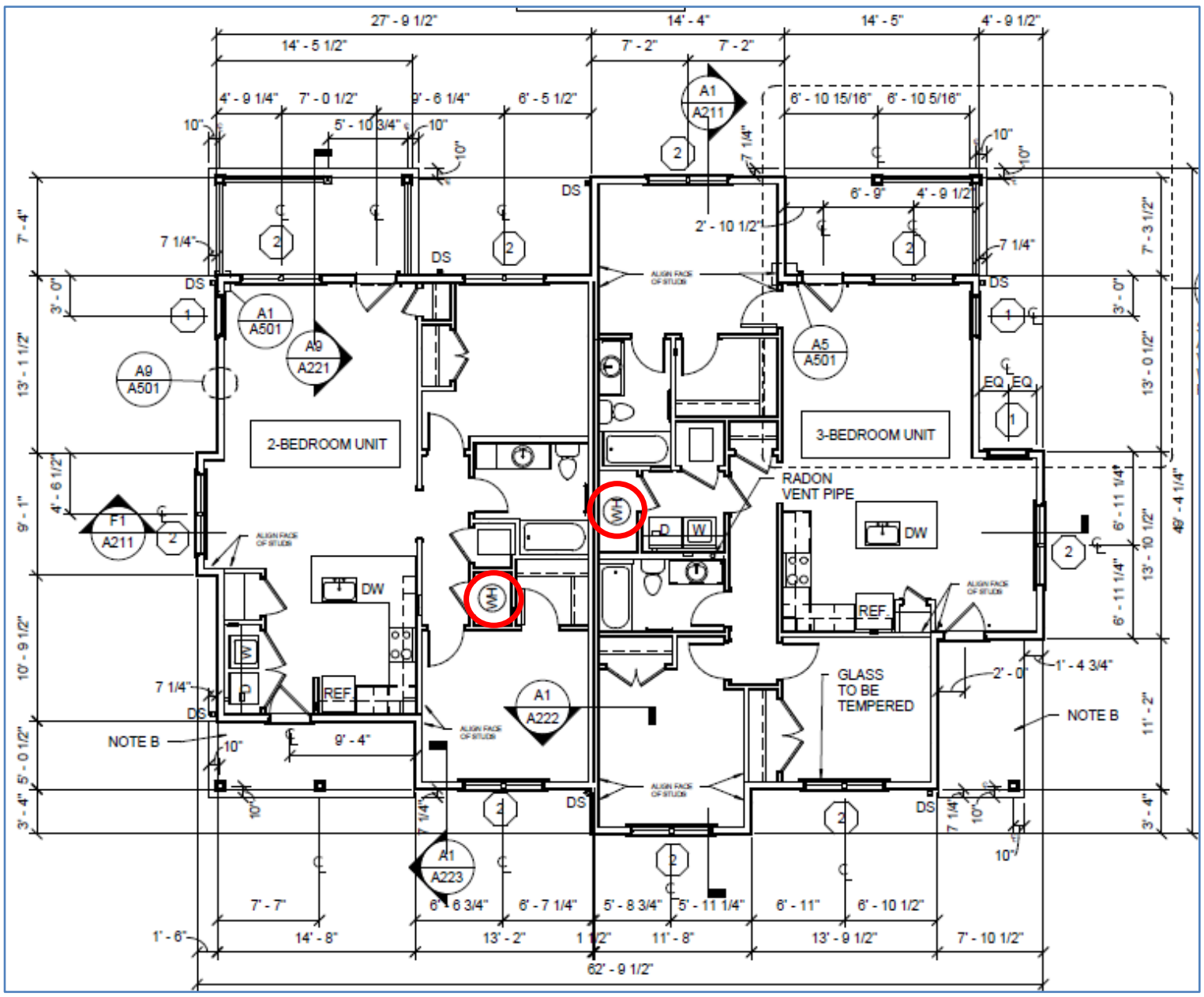

Figure 6. Typical LaFayette two-bedroom/three-bedroom duplex floor plan; red circles indicate HPWH locations. 


\section{Energy Model Analysis}

Energy simulation and optimization analyses were used at various stages during all three projects for decision making and performance evaluation. Various versions of Building Energy Optimization (BEopt $\left.{ }^{\mathrm{TM}}\right) \mathrm{E}+$ were used during project development, depending on project timing, but the final results presented are from BEoptE+2.3. The B10 benchmark is consistent with the 2009 International Energy Conservation Code, federal appliance standards in effect as of Jan. 1, 2010, and 2010 estimates of average lighting and miscellaneous electricity loads. Where appropriate (Savannah and LaFayette) electric appliances were chosen for heating and waterheating benchmarks, because no gas utility was available to the site.

\subsection{Improvements to Standard Home in Savannah Gardens}

BEopt modeling (Figure 7) indicated the most significant savings would be achieved from the HPWH by reducing total consumption by $1,017 \mathrm{kWh} / \mathrm{yr}(12 \%)$ compared to an electric resistance storage water heater (ERSWH). The modeled savings from adding $1 / 2 \mathrm{in}$. of rigid foam (ZipR) to the exterior sheathing was $118 \mathrm{kWh} / \mathrm{yr}(2 \%)$. Due to CZ 2 being cooling dominant, adding R-5 slab edge insulation (inSlab) increased energy consumption by $9 \mathrm{kWh} / \mathrm{yr}$, because it reduced the heating load and increased the cooling and HVAC fan loads by decoupling the slab from the relatively cool ground. Miscellaneous savings compared to the B10 Benchmark, 1,058 kWh $(8.5 \%)$, were achieved from removal of the gas-fueled fireplace, grille, and lighting; pool, hot tub, and spa equipment; and extra freezers and refrigerators.

\section{Savannah Garden Lot 207}

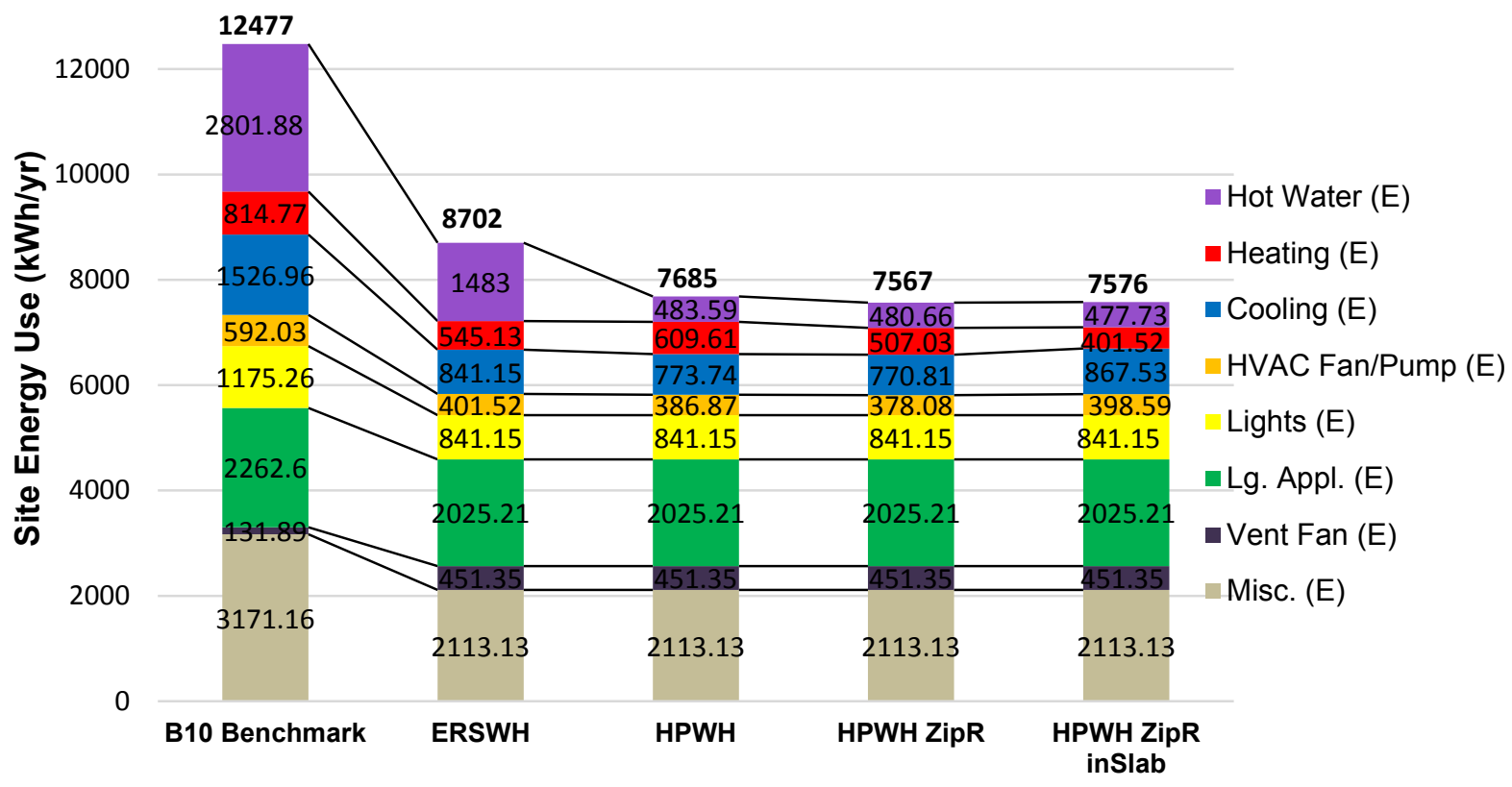

Figure 7. 39\% predicted site energy savings of as-built (HPWH ZipR) Savannah Gardens Lot 207 compared to the B10 Benchmark (BEopt+2.3) 


\subsubsection{Savannah Gardens REM/Rate Site Energy Analysis}

ENERGY STAR Version 3 compliance is a prerequisite for DOE Challenge Home/Zero Energy Ready certification. Two paths, prescriptive and performance, can be followed to achieve certification under ENERGY STAR Version 3. If the home meets the Benchmark Home Size, the builder can follow the prescriptive path to achieve qualification. Alternatively, the performance path uses energy modeling, in this case REM/Rate, to determine an ENERGY STAR Home Energy Rating System (HERS) Index Target, which is most commonly used by builders, because it allows for substitutions in the prescriptive requirements and tradeoffs in building envelope insulation and fenestration measures. The performance path incentivizes the design of smaller homes by including a size adjustment factor, but it also offers optional performance measures that can be traded off as appropriate to achieve the ENERGY STAR HERS Index Target. In this case, the house met the Benchmark Home Size; therefore, its adjustment factor is 1 . The ENERGY STAR Version 3 HERS Index Target is 79, and the test home exceeded this with a final HERS Index of 54.

In addition to assessing a HERS rating, REM/Rate simulation was completed to confirm Challenge Home qualification and EPAct tax credit $(\$ 2,000)$ eligibility. Through the model, Challenge Home specifications passed; however, the home did not qualify for the EPAct tax credit. The home is required to use $50 \%$ less site energy in combined heating and cooling loads than the reference home (based on the 2006 International Energy Conservation Code); also, 10\% of the total reduction must come from the envelope loads. Envelope improvements reduced heating and cooling loads by more than the minimum $10 \%$; however, the normalized modified end-use loads ${ }^{2}$ are $19.2 \mathrm{MBtu} / \mathrm{yr}$, slightly greater than the $50 \%$ target of $18.3 \mathrm{MBtu} / \mathrm{yr}$ (Figure 8). The cooling end-use loads are greater than the $50 \%$ target site energy.
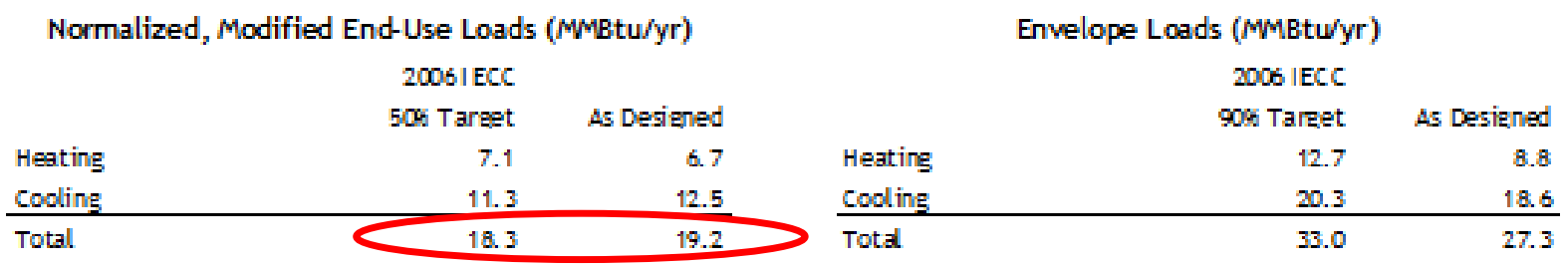

Figure 8. EPAct tax credit eligibility report generated by REM/Rate

The impact of an insulated slab on energy consumption was investigated. REM/Rate indicated that insulating the slab to R-5 would decrease the total cooling and heating load by $2.1 \mathrm{MBtu} / \mathrm{yr}$ and qualify for the EPAct tax credit (Figure 9).The designed cooling loads decreased little, but the heating loads were reduced $34 \%$ from the original design.

\footnotetext{
${ }^{2}$ The normalized modified end use load calculation is the HERS rating's fourth iteration of calculating annual building loads to develop a uniform rating method that is equitable and "fuel neutral" (Fairey et al. n.d.).
} 

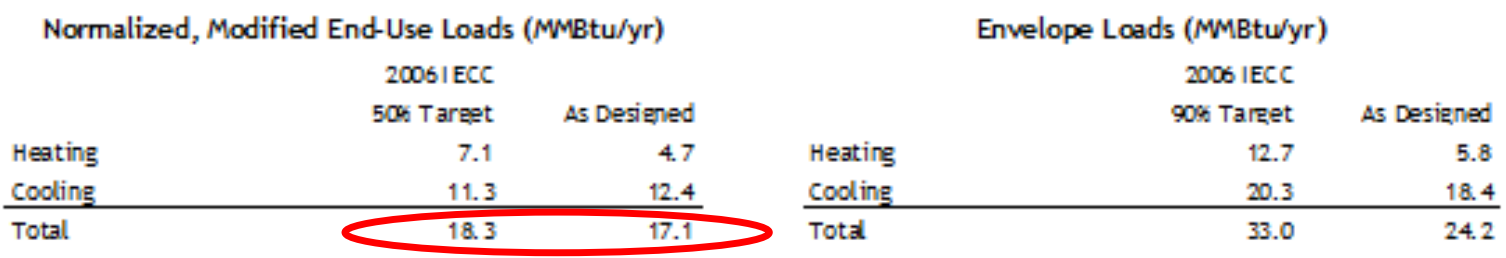

Figure 9. EPAct tax credit eligibility report generated by REM/Rate with exterior slab insulation

\subsubsection{Savannah Gardens REM/Rate Total Cost of Ownership Analysis}

Because a HERS Index is required for EarthCraft certification, Southface analyzed concurrent submissions for homes built by Chatham Home Builders in Savannah Gardens. For 13 homes built in 2013, the average HERS Index was 63; the test home's was 54. The HERS Index of the neighboring home monitored in this study is also 63. Predicted utility costs were compared for the test home and the neighboring home and resulted in a \$174 annual saving compared to the builder's standard practice. Using an incremental upgrade cost of $\$ 2,130$ and mortgage rate of $4.5 \%$, the resulting annual cash flow is $\$ 45$ positive.

\subsection{JMC Patrick Square Builder Base Package Optimization}

Southface analyzed BEopt models (Figure 10) for analysis of the JMC home, including the builder base package and an exploration of options for moving the ductwork from the vented attic to inside conditioned space. The builder's base package, which earned EarthCraft certification, was $9.5 \%$ more efficient than the B10 benchmark. Southface modeled the home with a sealed and insulated crawl space, with ducts in a furred-down chase below the attic ceiling, and several options for encapsulating ducts in the attic. In consultation with the builder and estimator, the team decided that the most replicable solution, which also met all ENERGY STAR Version 3 requirements, would be to encapsulate the roofline with ocSPF.

Full gutters are not standard for this builder, and community design guidelines require half-round gutters if they are installed. Because gutters can be omitted for slab foundations under ENERGY STAR Version 3 requirements, the builder felt that building a slab and placing the HVAC in the encapsulated attic were preferable to building a sealed crawl space and adding gutters to minimize costs. 


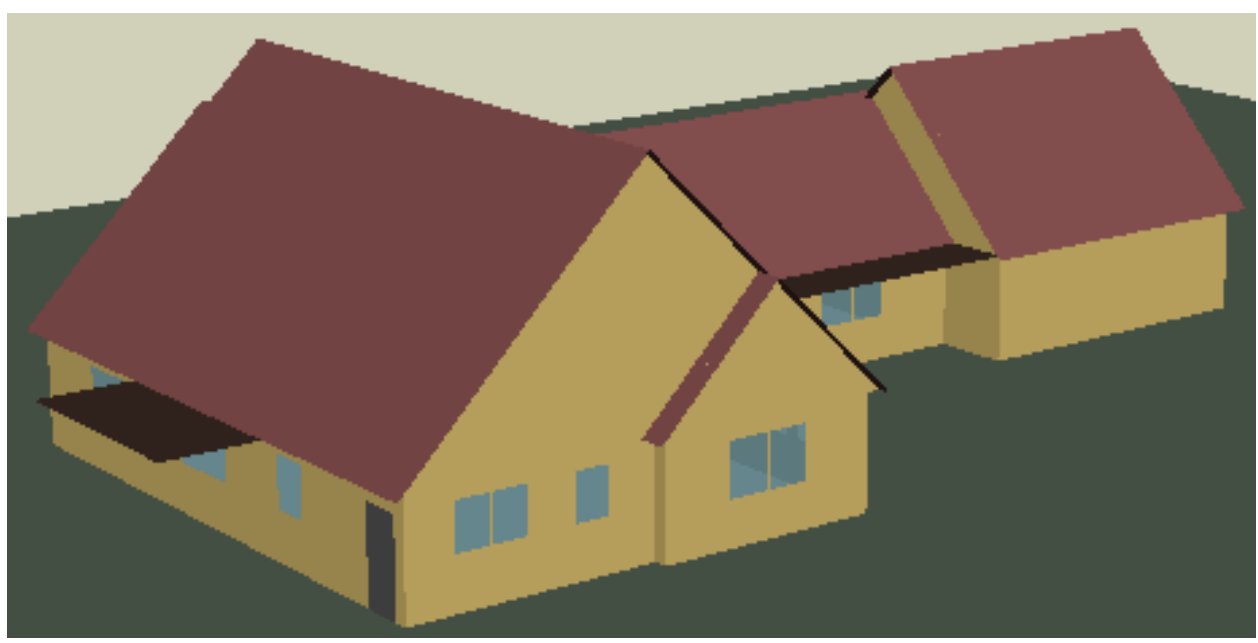

Figure 10. JMC BEopt model of the test home, View 1

To find improvements over the builder base model and meet Zero Energy Ready Home requirements, Southface proposed upgrades to all major systems and specifications (Table 3).

Table 3. JMC Patrick Square Proposed Base Package Upgrades and the As-Built Specifications

\begin{tabular}{|c|c|c|c|c|}
\hline Measure & B10 Benchmark & Base Spec & $\begin{array}{l}\text { Proposed } \\
\text { Package }\end{array}$ & As Built \\
\hline Foundation & $\begin{array}{l}\text { Elevated slab-on } \\
\text { grade }\end{array}$ & $\begin{array}{l}\text { Elevated slab-on } \\
\text { grade }\end{array}$ & $\begin{array}{l}\text { Elevated slab-on } \\
\text { grade }\end{array}$ & $\begin{array}{l}\text { Elevated slab-on } \\
\text { grade }\end{array}$ \\
\hline $\begin{array}{l}\text { Foundation } \\
\text { Insulation }\end{array}$ & Uninsulated & Uninsulated & $\begin{array}{c}\text { Exterior R-5 } \\
\text { extruded } \\
\text { polystyrene }\end{array}$ & Uninsulated \\
\hline $\begin{array}{c}\text { Wall } \\
\text { Construction }\end{array}$ & $2 \times 4,16$ in o.c. & $2 \times 4,16$ in o.c. & $2 \times 4,16$ in o.c. & $2 \times 4,16$ in o.c. \\
\hline Wall Insulation & $\begin{array}{l}\text { R-13 fiberglass } \\
\text { batts }\end{array}$ & $\begin{array}{l}\text { Grade I, R-13 } \\
\text { cellulose }\end{array}$ & $\begin{array}{c}\text { Grade I, R-13, } \\
\text { R-5 exterior } \\
\text { sheathing }\end{array}$ & $\begin{array}{l}\text { Grade I, R-13 } \\
\text { cellulose }\end{array}$ \\
\hline $\begin{array}{c}\text { Ceiling } \\
\text { Construction }\end{array}$ & Vented attic & Vented attic & Sealed attic & Sealed attic \\
\hline $\begin{array}{c}\text { Ceiling } \\
\text { Insulation }\end{array}$ & $\mathrm{R}-30$ & R-38 cellulose & R-20 ocSPF & R-20 ocSPF \\
\hline $\begin{array}{l}\text { Window } \\
\text { Ratings }\end{array}$ & $\begin{array}{c}\text { U 0.37, SHGC } \\
0.30\end{array}$ & $\begin{array}{c}\text { U } 0.35, \text { SHGC } \\
0.28\end{array}$ & $\begin{array}{c}\text { U } 0.33, \text { SHGC } \\
0.24\end{array}$ & $\begin{array}{c}\mathrm{U} 0.33, \mathrm{SHGC} \\
0.24\end{array}$ \\
\hline Infiltration & $\begin{array}{c}7 \mathrm{ACH}_{50}, 0.5 \\
\text { shelter coefficient }\end{array}$ & $7 \mathrm{ACH}_{50}$ & $2.5 \mathrm{ACH}_{50}$ & $2.5 \mathrm{ACH}_{50}$ \\
\hline $\begin{array}{l}\text { Heating } \\
\text { Efficiency }\end{array}$ & Gas $78 \%$ AFUE & Gas $92.5 \%$ AFUE & $\begin{array}{l}\text { Gas } 92.5 \% \\
\text { AFUE }\end{array}$ & $\begin{array}{l}\text { Gas } 92.5 \% \\
\text { AFUE }\end{array}$ \\
\hline $\begin{array}{c}\text { Cooling } \\
\text { Efficiency }\end{array}$ & 13 SEER & 13 SEER & 15 SEER & $\begin{array}{l}16 \text { SEER; } 1 \\
\text { stage } \\
\text { compressor }\end{array}$ \\
\hline $\begin{array}{c}\text { Supply Duct } \\
\text { Location }\end{array}$ & Vented attic & Vented attic & Sealed attic & Sealed attic \\
\hline
\end{tabular}




\begin{tabular}{|c|c|c|c|c|}
\hline Measure & B10 Benchmark & Base Spec & $\begin{array}{c}\text { Proposed } \\
\text { Package } \\
\end{array}$ & As Built \\
\hline $\begin{array}{l}\text { Return Duct } \\
\text { Location }\end{array}$ & Vented attic & Vented attic & Sealed attic & Sealed attic \\
\hline Duct Leakage & $\begin{array}{l}\text { R-8 insulation; } \\
15 \% \text { total }\end{array}$ & $\begin{array}{l}\mathrm{R}-8 \text { insulation, } 5 \% \\
\text { to outside }\end{array}$ & $\begin{array}{c}\text { R-10 insulation, } \\
0 \% \text { to outside }\end{array}$ & $\begin{array}{c}\text { R-10 insulation, } \\
0 \% \text { to outside }\end{array}$ \\
\hline Ventilation & $\begin{array}{l}\text { Exhaust } 2010 \\
\text { ASHRAE } 62.2\end{array}$ & $\begin{array}{c}\text { Supply } 2010 \\
\text { ASHRAE } 62.2\end{array}$ & $\begin{array}{c}\text { Supply } 2010 \\
\text { ASHRAE } 62.2\end{array}$ & $\begin{array}{c}\text { Supply } 2010 \\
\text { ASHRAE } 62.2\end{array}$ \\
\hline $\begin{array}{l}\text { Hot Water } \\
\text { Efficiency }\end{array}$ & $\begin{array}{l}0.59 \mathrm{EF} \text {, gas } \\
\text { storage }\end{array}$ & $\begin{array}{c}0.61 \mathrm{EF} \text {, gas } \\
\text { storage; } \\
\mathrm{R}-0, \text { trunk branch } \\
\text { copper }\end{array}$ & $\begin{array}{l}0.67 \mathrm{EF} \text {, gas } \\
\text { storage; R-0, } \\
\text { trunk branch } \\
\text { copper }\end{array}$ & $\begin{array}{c}\text { ENERGY STAR } \\
\text { tankless; } 0.82 \\
\text { EF gas }\end{array}$ \\
\hline Lighting & $\begin{array}{l}34 \% \text { compact } \\
\text { fluorescent lamps }\end{array}$ & $\begin{array}{l}90 \% \text { incandescent; } \\
10 \% \text { compact } \\
\text { fluorescent lamps }\end{array}$ & $\begin{array}{l}80 \% \text { ENERGY } \\
\text { STAR qualified }\end{array}$ & $\begin{array}{c}90 \% \\
\text { incandescent; } \\
\text { 10\% compact } \\
\text { fluorescent } \\
\text { lamps }\end{array}$ \\
\hline Appliances & $\begin{array}{l}\text { Benchmark } \\
\text { Standards }\end{array}$ & $\begin{array}{c}\text { Gas range; } \\
\text { ENERGY STAR } \\
\text { dishwasher } 260 \\
\text { kWh }\end{array}$ & $\begin{array}{c}\text { Gas range; } \\
\text { ENERGY STAR } \\
\text { dishwasher } 260 \\
\text { kWh }\end{array}$ & $\begin{array}{c}\text { Gas range; } \\
\text { ENERGY STAR } \\
\text { dishwasher } 260 \\
\mathrm{kWh} \\
\end{array}$ \\
\hline
\end{tabular}

The proposed package would meet the project goals of achieving ENERGY STAR certification and result in total source energy consumption savings of $31.4 \mathrm{MBtu} / \mathrm{yr}(19 \%)$ relative to the B10 Benchmark (Figure 11). This would be an 11\% improvement over the builder's base package and save $17 \mathrm{MBtu} / \mathrm{yr}$. The builder did not view the additional costs to meet mandatory requirements for a Zero Energy Ready Home, including further window and plumbing upgrades, as cost-effective. The as-built package was only a modest improvement over base specifications; it saved $2.7 \mathrm{MBtu} / \mathrm{yr}(2 \%)$. 


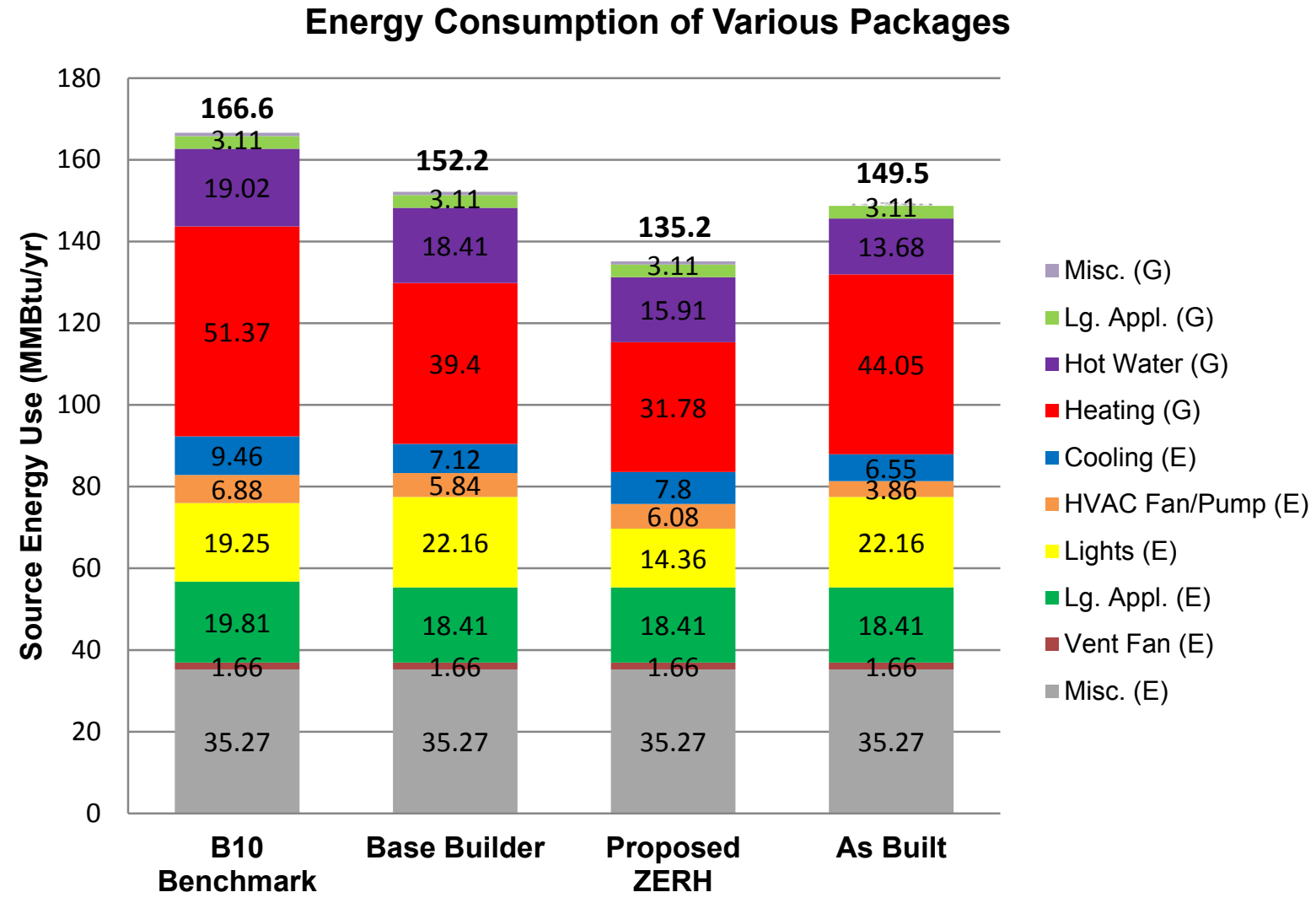

Figure 11. JMC builder package, proposed, and as-built BEopt comparison

The heating source energy of the as-built home increased from the builder's base package. Several changes to the building specifications - which have positive impacts on other components of energy consumption, indoor air quality, buyer appeal, and durability - combined to produce this result. For instance, the choice to bring the HVAC system and ducts into conditioned space by encapsulating the roofline with R-20 ocSPF resulted in a significant increase in total U-value times surface area along the insulated top surface of the house. Insulating to R-20 with ocSPF (5.5-6 in. thick) is common practice because that is the perceived point of diminishing returns and thickness for which most ocSPF product manufacturers are approved by the International Code Council Evaluating Service. Even though this strategy reduced duct and enclosure leakage and enclosed the system in a semi-conditioned space, the combined effect of this change alone was a net increase of nearly $4 \mathrm{MBtu} / \mathrm{yr}$.

The reported incremental cost for an encapsulated crawlspace foundation with full gutters and standard R-38 attic over the raised slab foundation with an ocSPF encapsulated roofline was more than $\$ 15,000$. This is primarily due to the foundation cost.

\subsection{LaFayette Domestic Hot Water Analysis}

Parametric energy model analyses of LaFayette two- and three-bedroom units were conducted using BEopt Versions 1.1-2.3 throughout the design and specification process, but all results presented are products of BEoptE+2.3. The home's geometric features and builder's base 
specifications were entered and compared to the B10 benchmark (Figure 12). The as-built specifications achieved 31\% source energy savings over the B10 benchmark for both units.

\section{LaFayette Model Results}

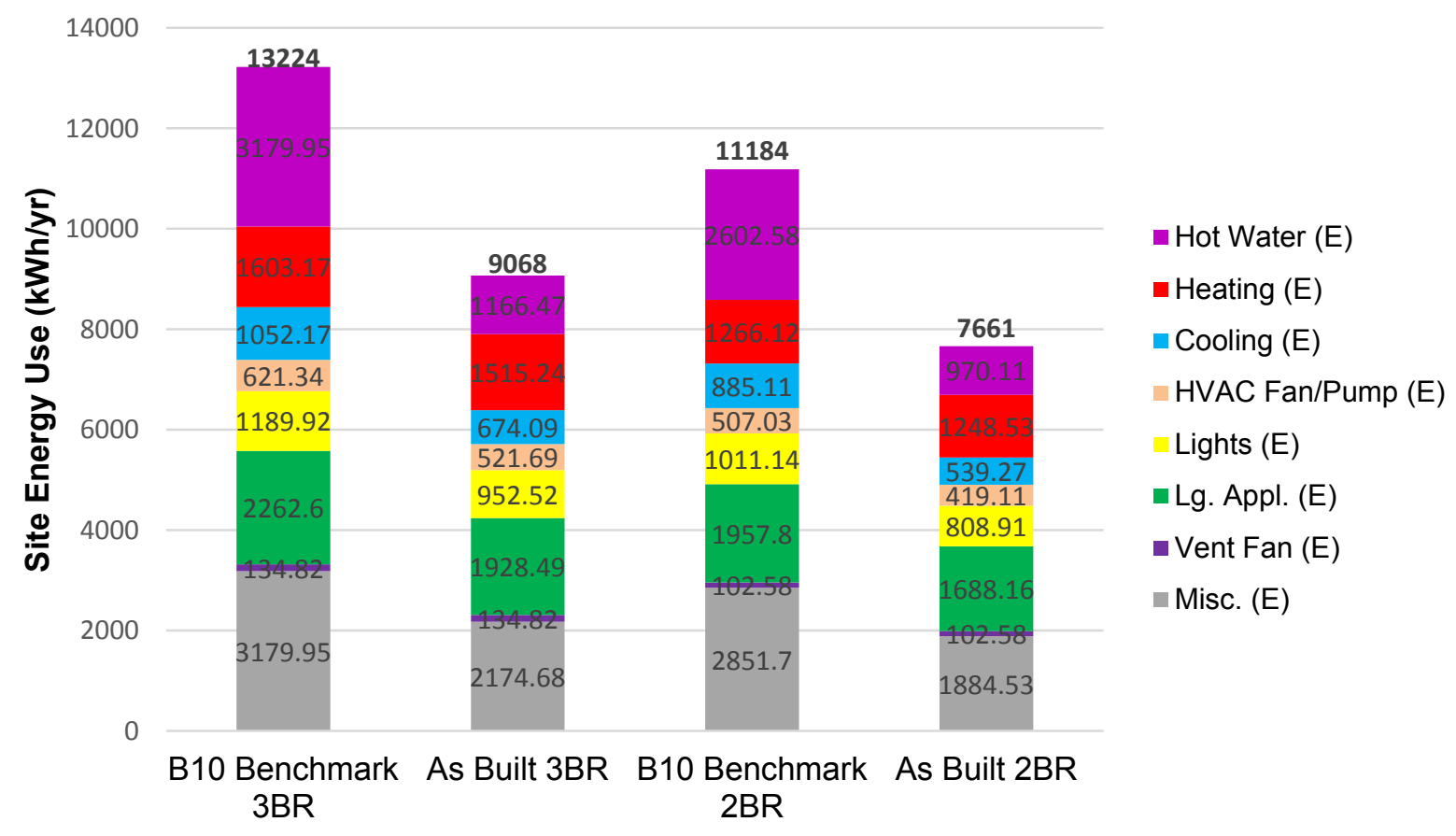

Figure 12. BEoptE+2.3 energy model comparisons of as-built to B10 Benchmark for the two- and three-bedroom LaFayette unit types predicts $31 \%$ source energy savings for both.

The original design of the duplex was to include solar thermal water heating for each unit, as seen in Figure 13. Southface modeled two different-sized solar thermal arrays $\left(40 \mathrm{ft}^{2}\right.$ and $\left.64 \mathrm{ft}^{2}\right)$, electric tankless, and an HPWH to analyze the potential savings of various DHW technologies compared to a standard electric resistance storage water heater. Results are in Table 4 and Figure 14. For the three-bedroom unit, the solar thermal water heaters produced the greatest total energy savings (30\% for $40 \mathrm{ft}^{2}$ and $36 \%$ for $64 \mathrm{ft}^{2}$ ) followed by HPWH (27\%). The electric tankless water heater produced minimal energy savings (2\%). An analysis of simple payback was performed using standard installed costs for all water heater types and an average electricity price of $\$ 0.11 / \mathrm{kWh}$. For the HPWH, the cost included the ducting to connect the utility closet to the attic. Because the installed cost of a solar thermal system is more than three times as expensive as the HPWH, the simple paybacks for the systems were quite different. The simple payback for the HPWH is 10 years, which is within the expected useful life of the appliance. The simple payback for the $64-\mathrm{ft}^{2}$ solar thermal system is 33 years, beyond the age at which the appliance would be expected to require repair or replacement. LHA decided to install a ducted HPWH based on this analysis. 


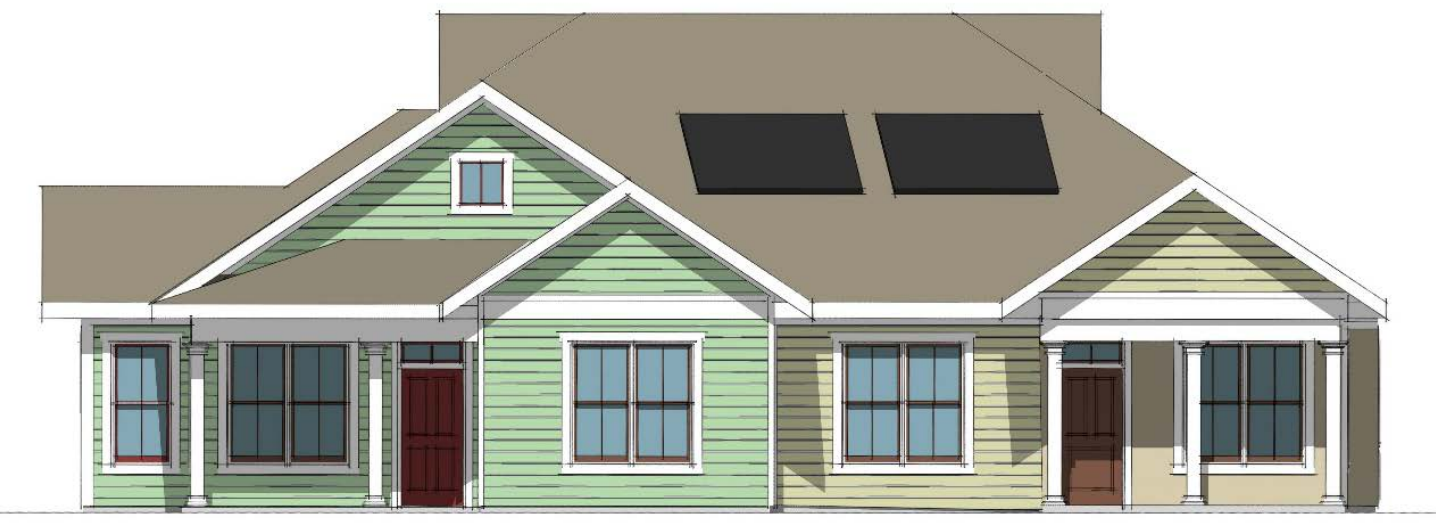

Figure 13. Front elevation of LaFayette duplex with the original plan to include a south-facing solar thermal DHW system

Table 4. LaFayette Water Heating Analysis Revealed HPWH Provided the Best Value

\begin{tabular}{c|c|c|c}
\hline Water Heater & Installed Cost & $\begin{array}{c}\text { Energy Savings } \\
\text { (per year) }\end{array}$ & $\begin{array}{c}\text { Simple Payback } \\
\text { (years) }\end{array}$ \\
\hline $\begin{array}{c}\text { Electric Resistance } \\
\text { Storage Water Heater }\end{array}$ & $\$ 500$ & - & - \\
Tankless & $\$ 700$ & $126 \mathrm{kWh}(2 \%)$ & 50 \\
HPWH & $\$ 2,100$ & $1,437(27 \%)$ & 10 \\
\hline Solar Thermal 40 $\mathbf{f t}^{2}$ & $\$ 7,500$ & $1,630 \mathrm{kWh}(30 \%)$ & 42 \\
\hline Solar Thermal 64 $\mathbf{f t}^{2}$ & $\$ 7,500$ & $1,920 \mathrm{kWh}(36 \%)$ & 33 \\
\hline
\end{tabular}

${ }^{a}$ Simple payback is calculated using incremental cost to install (i.e., installed cost less than $\$ 500$ for an electric resistance storage water heater)

Three-Bedroom LaFayette Model Site Energy Use

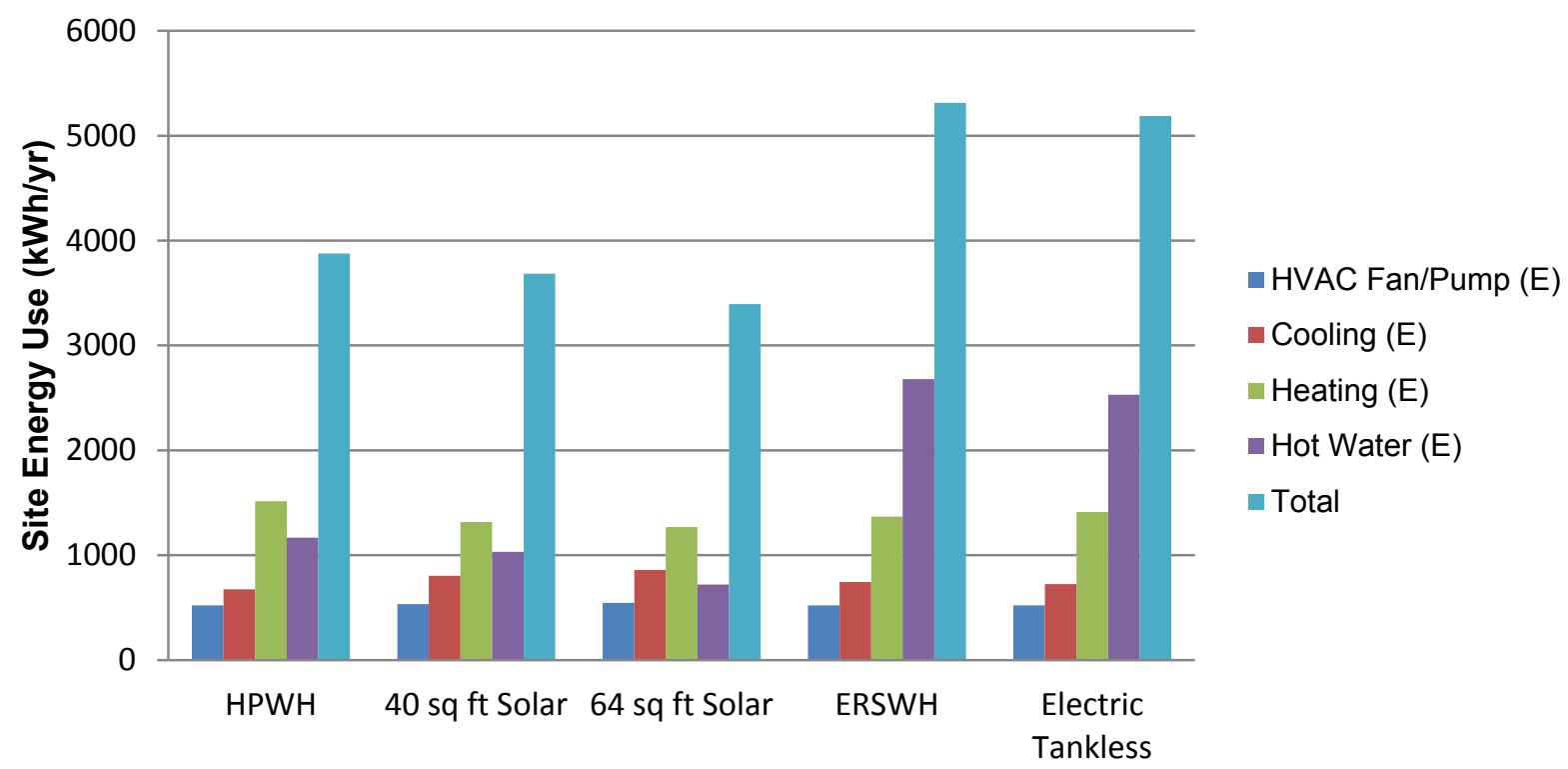

Figure 14. Modeling results of various DHW technologies 


\section{Construction and Quality Management Systems}

\subsection{Wall Assemblies}

Three wall assemblies were constructed at the New Construction Test Houses (Table 5).

Savannah Gardens and JMC Patrick Square used $2 \times 4$ framing with R-13 cavity insulation, but Savannah added Huber ZipR consisting of $1 / 2$ in. of continuous exterior foam, R-3.6 (Figure 15). LaFayette used advanced framing with $2 \times 6$ studs and Johns Manville Spider as cavity insulation.

Table 5. Test Home Wall Assemblies

\begin{tabular}{c|c|c|c}
\hline Test Home & Framing & Cavity Insulation & Exterior Insulation \\
\hline Savannah Gardens & $2 \times 4$ & $\begin{array}{c}\text { R-13 fiberglass } \\
\text { batts }\end{array}$ & $\begin{array}{c}1 / 2-\text { in. Huber ZipR } \\
\text { JMC Patrick Square }\end{array}$ \\
LaFayette & $\begin{array}{c}2 \times 4 \\
\text { advanced framing }\end{array}$ & $\begin{array}{c}\text { Manville Spider } \\
\text { fiberglass }\end{array}$ & None \\
\hline
\end{tabular}

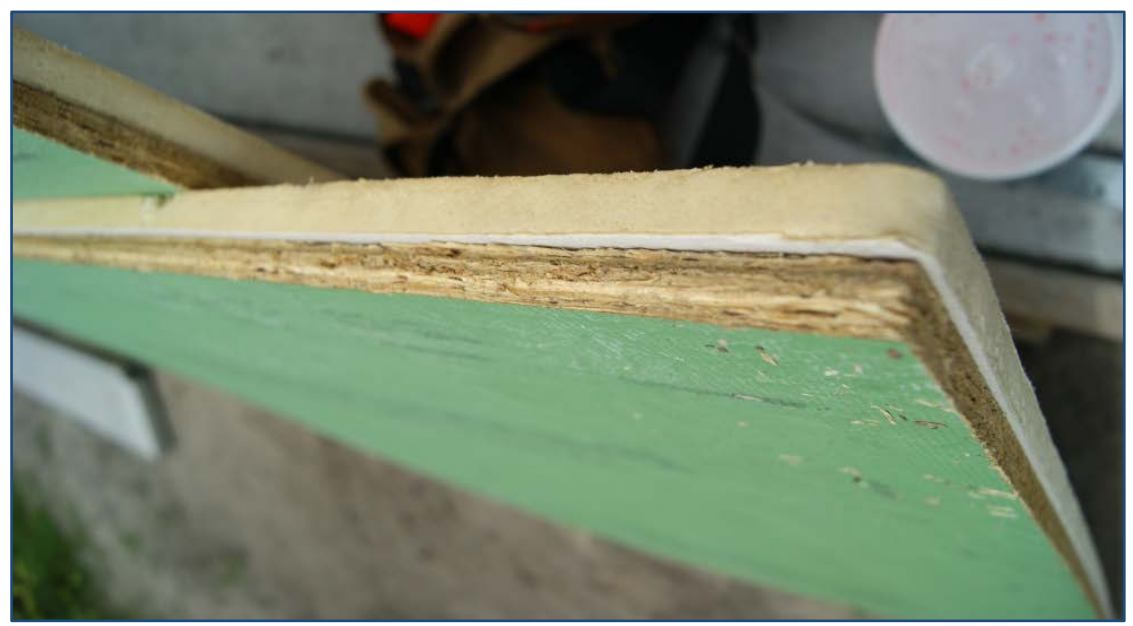

Figure 15. ZipR cross-section

\subsubsection{Advanced Framing Details}

Several advanced framing details were included in LaFayette's construction drawings, including two-stud corners, ladder tees at partition walls, and a header design that left $3-1 / 2 \mathrm{in}$. of cavity above all windows and doors for insulation (Figure 16 and Figure 17). The drawings also showed a single top plate, but after a discussion about the hardware that would be needed to strap intersecting walls together and the framer's process of standing and racking the walls to make them plumb and square, this was abandoned for a conventional double top plate. The framer had implemented some of these details on a previous EarthCraft-certified project and was comfortable using them on this project. 


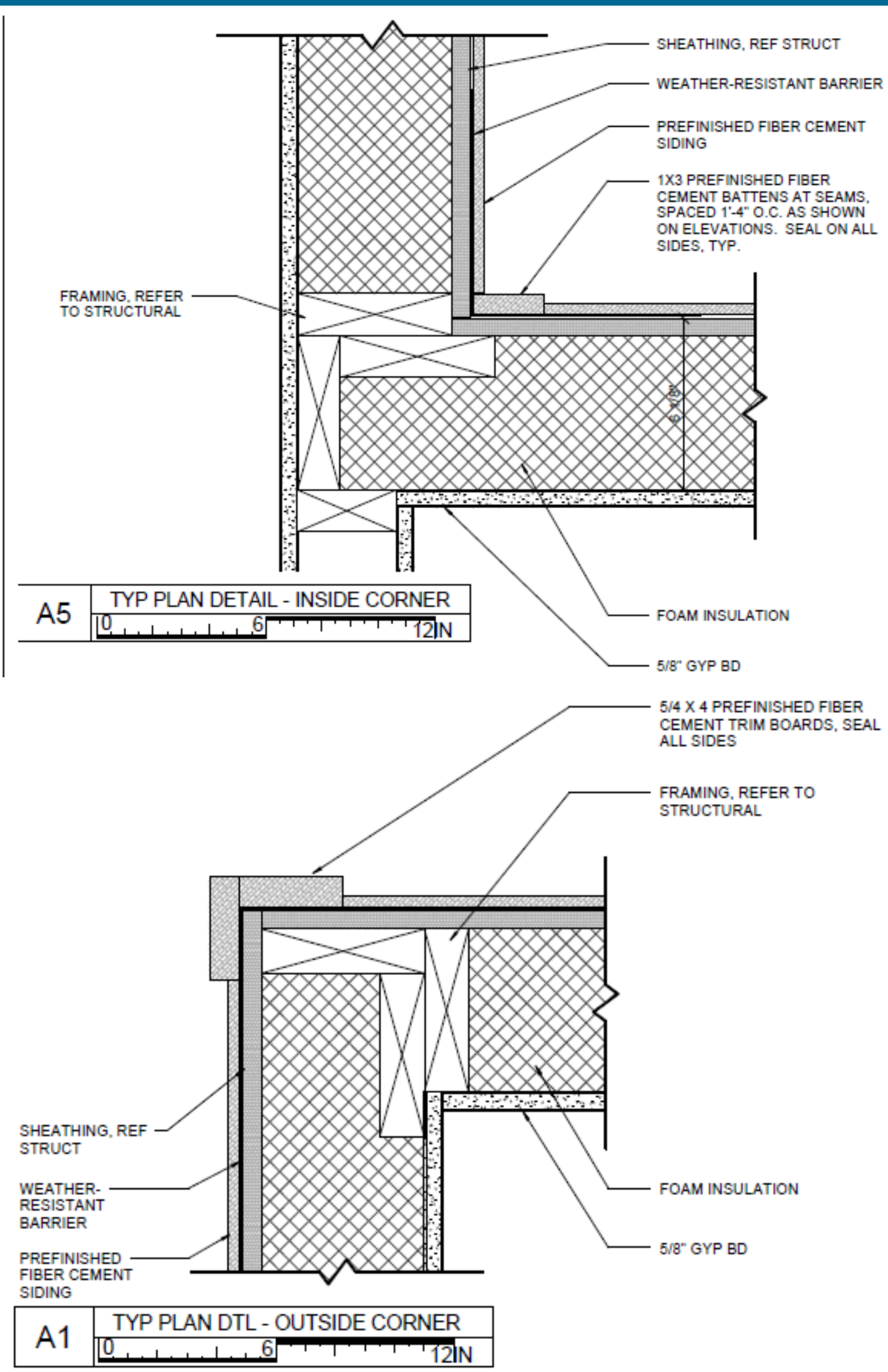

Figure 16. Framing details of two-stud corners from LaFayette construction drawings 


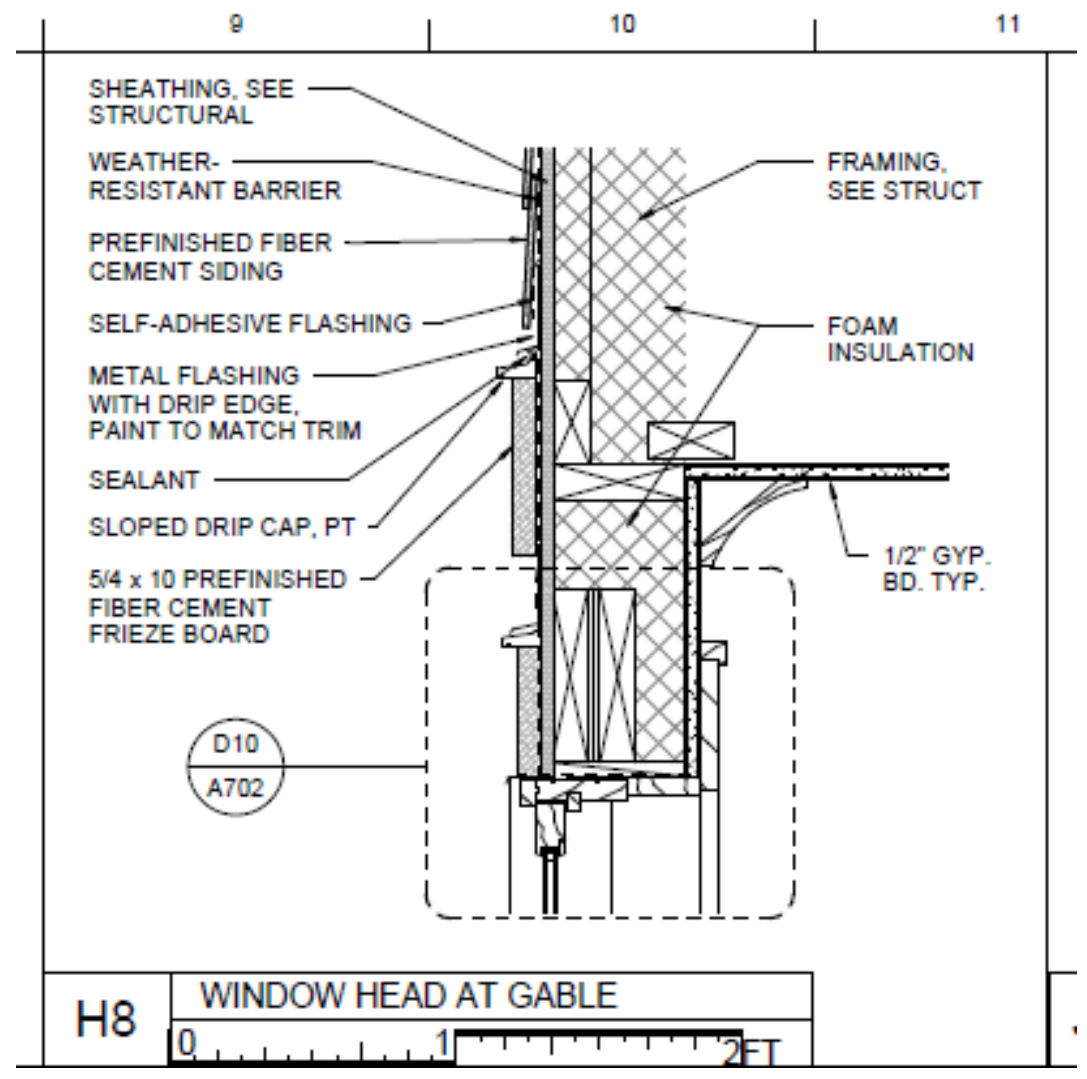

Figure 17. Window head at gable details from construction drawings

\subsubsection{Spider Spray Installation}

Johns Manville Spider spray-in fiberglass insulation was installed in the wall cavities at LaFayette. Spider insulation is installed similarly to wet/damp spray cellulose, except the fiberglass is sprayed with a small amount of acrylic binder (glue) to adhere the insulation to the cavities and perhaps avoid the need to install netting. Spider insulation is installed at a lower density $\left(1.8 \mathrm{lb} / \mathrm{ft}^{3}\right)$ than cellulose $\left(3.5 \mathrm{lb} / \mathrm{ft}^{3}\right)$, using less material and having a slightly better Rvalue/in of 4.2 versus 3.8 for dense-pack cellulose (Johns Manville 2014; DOE 2015). Johns Manville provided additional technical support by flying two product engineers to the jobsite to witness the first day of Spider installation. This was extremely beneficial to the project, because the engineers discovered that the installation crew was using a hose head and spray nozzles for spray-applied cellulose instead of the specified head and nozzles for Spider. The improper nozzles were delivering a stream of adhesive instead of a mist, and the air pressure on the hose was causing too much fiberglass to be put into the cavity. After replacing the nozzles with Spider nozzles, the insulation still was not cleanly adhering and filling the cavity in a few passes. The cavity filled quickly and overflowed onto the floor and required additional vacuuming. Despite being trained onsite by two Johns Manville Spider technical representatives, installation was tedious and required vacuuming of excess blown fiberglass off the floor (Figure 18). 


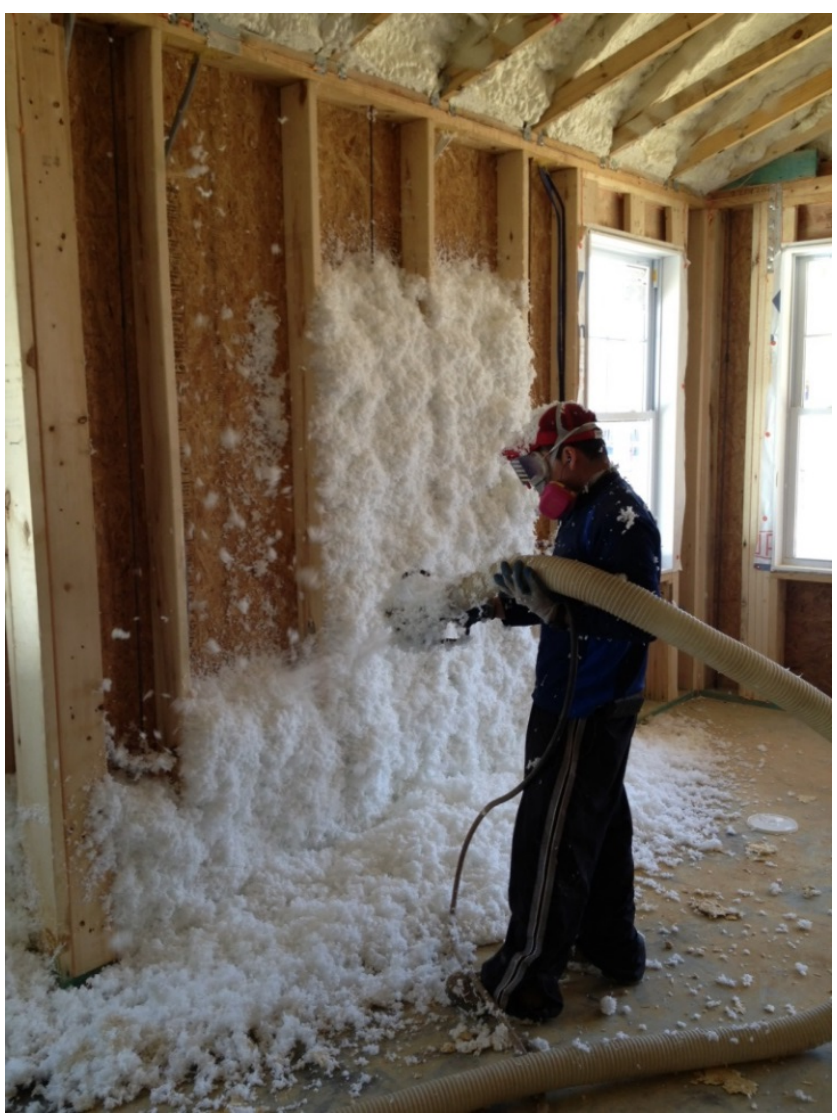

Figure 18. Installation of Johns Manville Spider insulation

The engineers also discovered that the rotating head used to shave the insulation flush to the studs was for cellulose, not fiberglass. This left a rough finish on the insulation (Figure 19). The Johns Manville representative provided a calibrated plunger to test the density of the installation and measure its installed R-value. Tests of this initial installation consistently yielded R-values of R-21 (Johns Manville specifies R-23); however, BEopt modeling predicted that this would have an insignificant effect.

Samples were taken in several locations throughout each building during subsequent predrywall inspections. Results were consistently between R-22 and R-21. An unintended consequence of the ladder-tee advanced framing was that the shaving device did not have support on both edges, and consistently gouged out insulation in the adjacent cavity.

The spray rig failed while the insulation was being installed on the fifth building at the first site. To stay on schedule, the crew installed netting and dense packed the cavities with dry product (Figure 20). From this, the installer discovered that the time spent installing the netting was much cheaper and faster than applying adhesive, shaving, and vacuuming for the spray-applied application and used this method for the remainder of the project. Unfortunately, the density tester is calibrated for spray-applied product only and could not be used to measure the R-value of netted installations. 


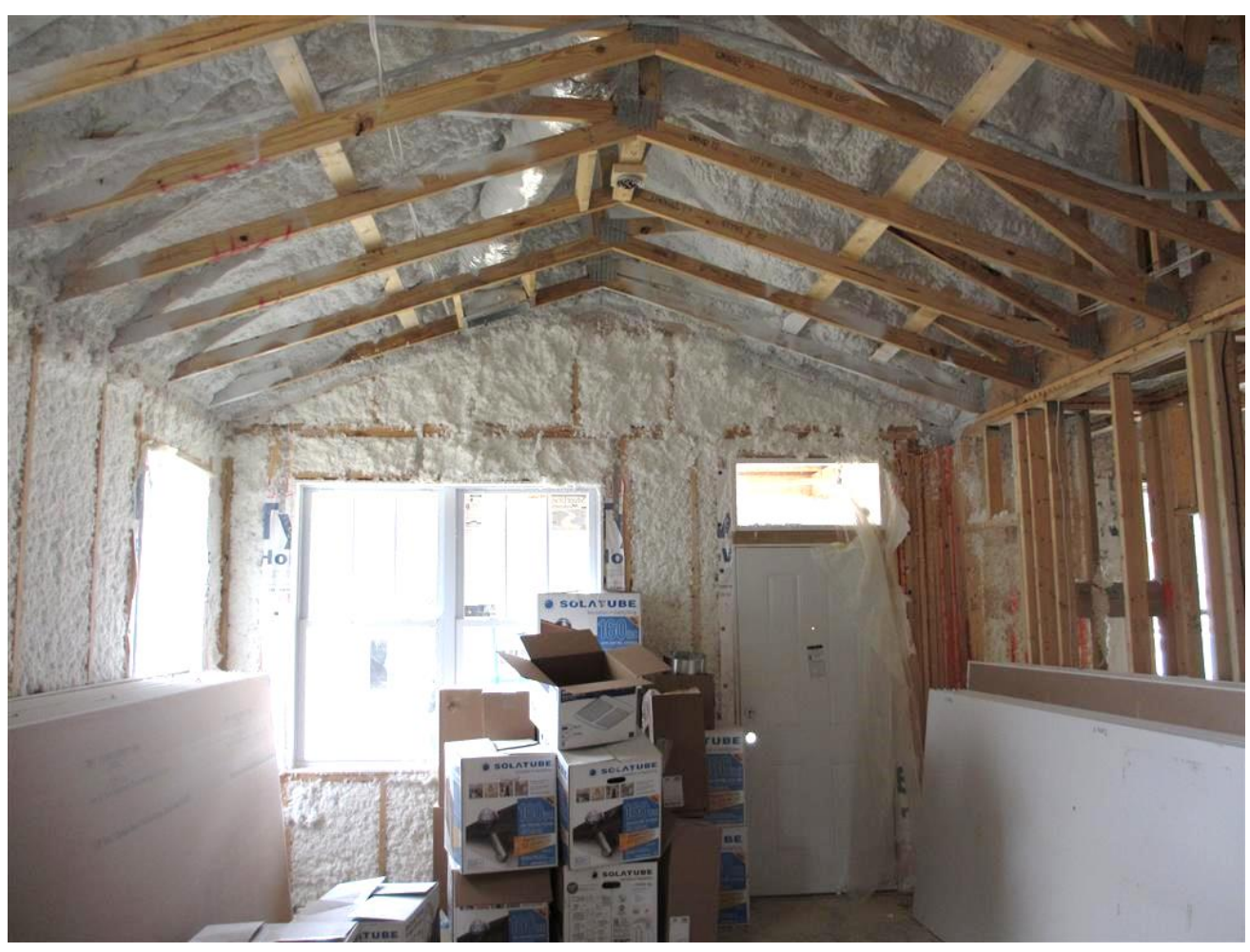

Figure 19. Spray-applied Spider insulation

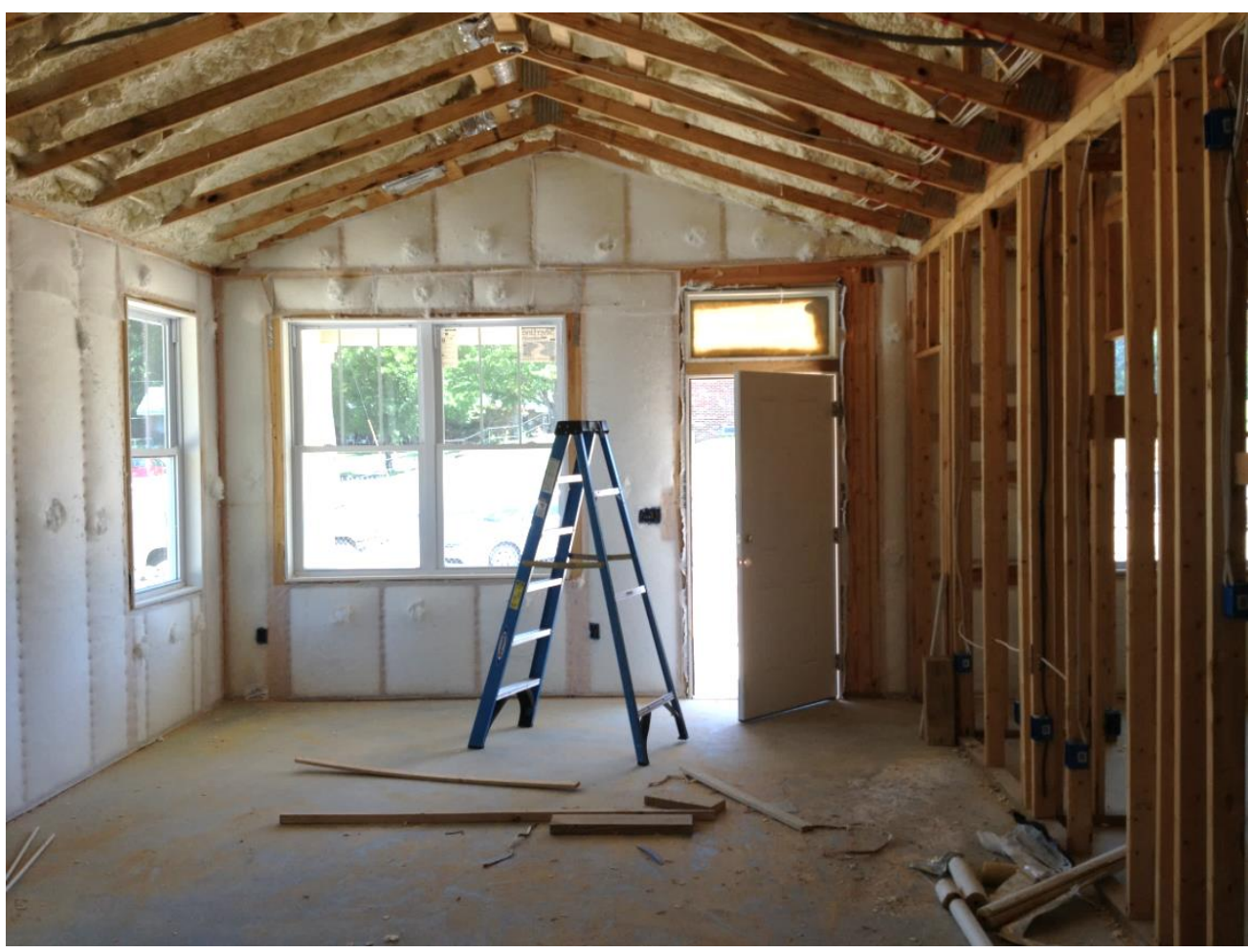

Figure 20. Netted Spider insulation 


\subsection{Sealed Attics}

The attics at all three sites were encapsulated with approximately 6 in. of ocSPF applied to the oriented strand board roof decking (R-20). This system created semi-conditioned attics in which to place the air handling units for the JMC and Savannah Gardens projects and to run the supply and return ductwork for all three projects. The air handling units in LaFayette were placed in locked mechanical closets in the living zones.

Although this strategy has the tremendous advantages of increased enclosure airtightness, decreased HVAC system leakage to outside, and enclosing the HVAC system in a semiconditioned space, resistance to heat transfer through the attic thermal barrier is decreased compared to code values. Ceiling R-value requirements of the 2009 International Energy Conservation Code are R-30 (CZ 2 and 3) and R-38 (CZ 4). Builders who install lower R-values on rooflines can choose either the UA alternative or simulated performance pathways for meeting code requirements to demonstrate compliance with energy code by either increasing insulation values elsewhere in the home or increasing other energy-efficiency features beyond code minimums (Klocke, Faakye, \& Puttagunta, 2014) (ICC, 2009).

\subsection{Foundations-Slab Edge Insulation}

JMC Patrick Square and LaFayette both had 1 in. of rigid foam insulation installed around their elevated slabs (Table 6). The Savannah Gardens home was built on an uninsulated slab on grade, because BEopt energy models predicted insulation would increase annual energy consumption by decoupling the slab from the cool ground in a cooling-dominant climate.

Table 6. Test Home Slab-Edge Insulation

\begin{tabular}{c|c|c|c}
\hline Test Home & Slab Type & Slab Edge Insulation Type & R-Value \\
\hline Savannah Gardens & On grade & None & N/A \\
JMC Patrick Square & Elevated & Interior & 5 \\
LaFayette & Elevated & Exterior & 5 \\
\hline
\end{tabular}

Before slabs were formed in LaFayette, a meeting was held with the contractor's preconstruction manager and site superintendent, the project architect, and crew leaders from the framing, electrical, and masonry contractors. The purpose was to review details contained in the drawings and to coordinate the installation of the slab edge insulation and additional details. This discussion answered the framer's questions about aligning the sheathing with the insulation (Figure 21 and Figure 22). It was determined that the masons installing the brick plinths covering the slab edges would install the insulation board ahead of their brickwork. This would minimize the amount of time the insulation was exposed to the elements and better ensure its protection from construction damage. The concrete crew would install the insulation board where it occurs between the building slab and the porch and would place it just before the porch pour. Here, the insulation also functions as an expansion joint to allow differential movement between the two slabs.

No such kick-off meeting occurred during construction at JMC Patrick Square. Issues arose about installing the slab insulation, because it was not part of the original plans; however, it became necessary to meet the UA alternative due to the decrease in insulation value from R-38 at the attic floor to R-20 at the roofline. An elevated slab foundation with concrete masonry unit 
stem walls was constructed. This is a typical construction technique in the Southeast that is used to raise the floor level of the home for storm water management and architectural aesthetics. Instead of constructing a "floating slab" by leaving the concrete masonry units unaltered, the builder notched the concrete masonry units to support the poured slab. Thus, the proposed slab insulation solution was to insulate the slab exterior with 1-in. (R-5) of extruded polystyrene foam board.

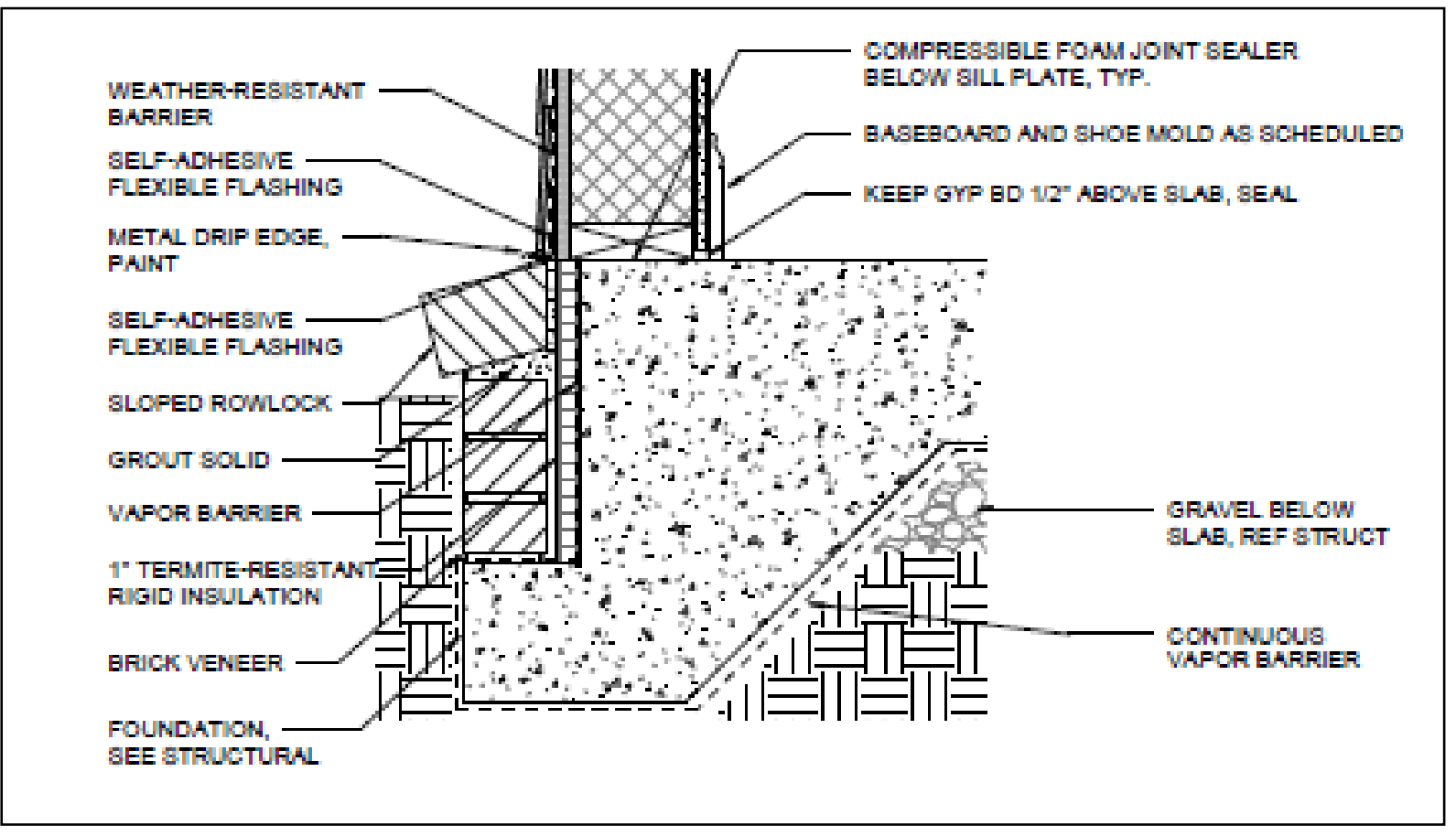

Figure 21. LaFayette slab edge insulation detail 


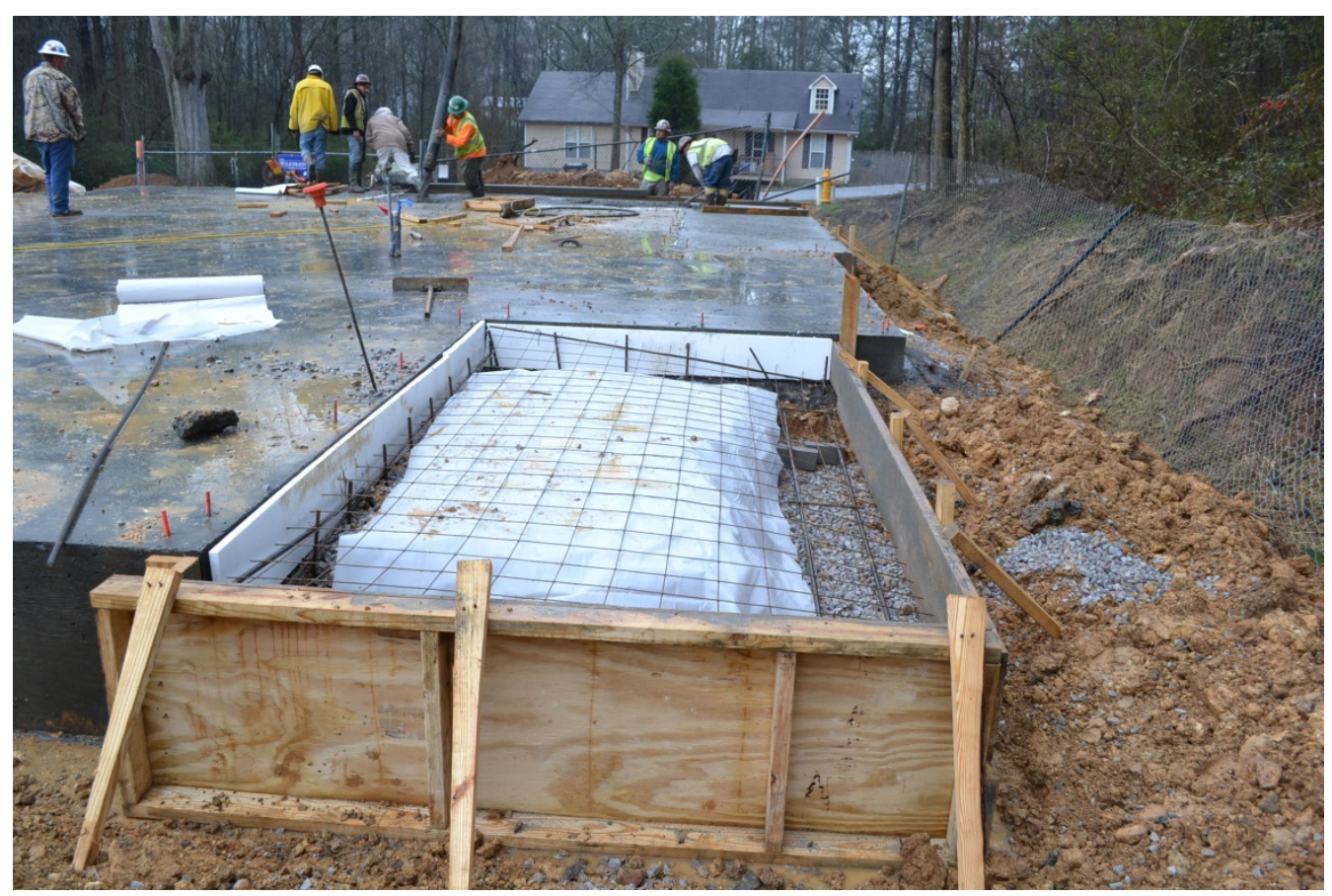

Figure 22. LaFayette slab edge insulation installed before the porch pour

The builder chose instead to attempt an interior and gap insulation solution (Figure 23) to eliminate the costs associated with providing a protective covering for the exterior foam. The lower section of the slab is insulated, and the top half of the slab filling in the concrete masonry unit notches is exposed to the stem wall, creating a thermal bridge. The cost of the slab insulation was $\$ 1,645$ over initial budget.

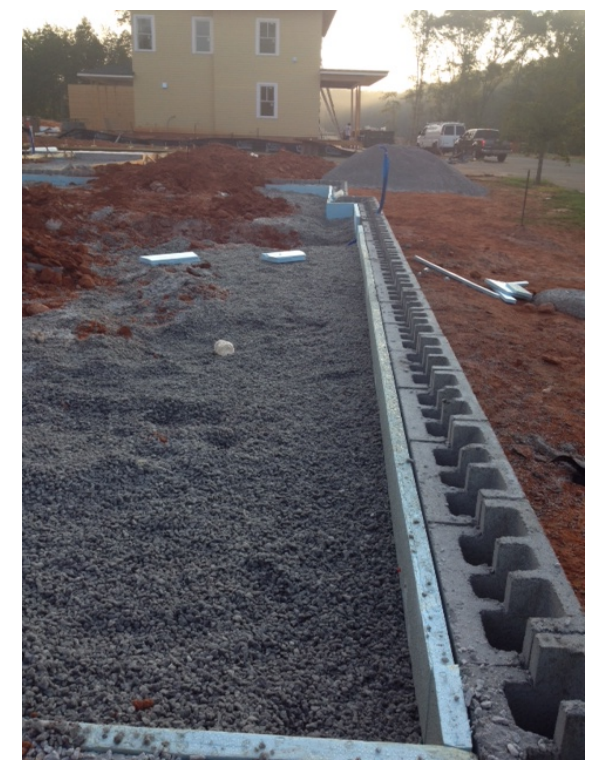

Figure 23. JMC elevated slab construction in progress showing gap insulation and stem wall 
The thermal bridge was evident during infrared thermography investigations that were conducted on a cool morning at the junction of the slab and exterior wall (Figure 24). The coldest temperatures were on the floor at the exterior wall junction. The image also depicts insulation defects and thermal bridging through the wood studs.

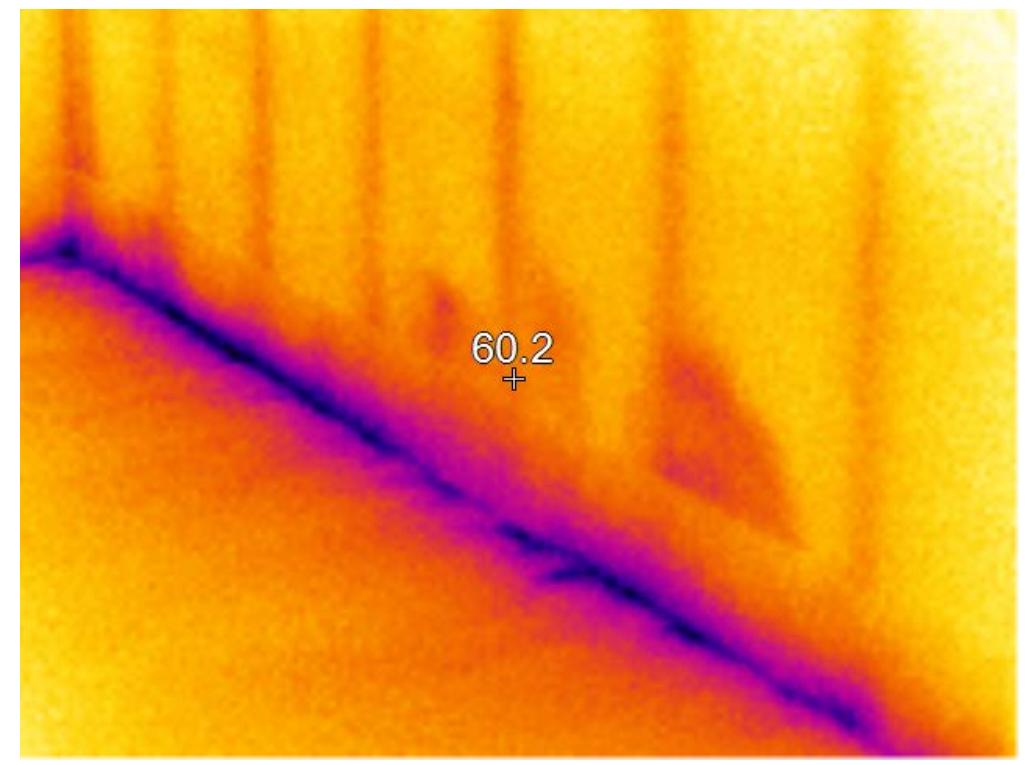

Figure 24. JMC thermal image facing exterior wall showing heat transfer through the slab

\subsection{Domestic Hot Water}

Table 7 documents the DHW technology installed in each test home. The test homes in Savannah Gardens and LaFayette had electric energy service only, so HPWHs were chosen for being the most efficient and cost-effective solution for DHW. JMC Patrick Square had a natural gas line to serve the kitchen range and oven, furnace, and DHW. The team recommended an ENERGY STAR gas storage water heater (EF 0.67) upgrade from the base gas storage tank (EF 0.61), but the builder chose a gas tankless unit because of its familiarity with the technology, which was an upgrade option of its package, and because the builder believes that homebuyers view tankless water heaters favorably.

Table 7. Test Home Water Heater

\begin{tabular}{c|c|c|c}
\hline Test Home & Water Heater & Location & $\mathbf{E F}^{\mathbf{a}}$ \\
\hline Savannah Gardens & Heat pump & Encapsulated attic & 2.3 \\
JMC Patrick Square & Tankless gas & Garage & 0.82 \\
LaFayette & Heat pump & $\begin{array}{c}\text { Closet - ducted to } \\
\text { encapsulated attic }\end{array}$ & 2.3 \\
\hline
\end{tabular}

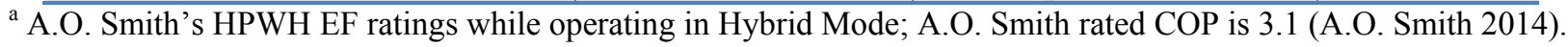
The installed tankless was a Rinnai Value Series V65i (Rinnai 2015).

The HPWHs in LaFayette are in the mechanical closets behind locked doors with door shoes installed. The doorways were sealed to reduce noise and air transfer to the living space. Noise reduction was the primary reason to duct the HPWHs to the attic and not use a louvered door, because previous studies have reported noise as the major complaint from tenants who live with 
HPWHs (Chasar and Martin 2013). Figure 25 shows a schematic of the ducted HPWH installation in the mechanical closet. The ceiling of the mechanical closet to the encapsulated attic has a transfer duct to provide intake air (Figure 26, left); the HPWH's exhaust is directly ducted to the attic (Figure 26, right). The distance between the ducts' terminals is to be a minimum of 5 feet, and the different orientations of the ducts are to prevent cool exhaust air from recirculating into the intake duct.

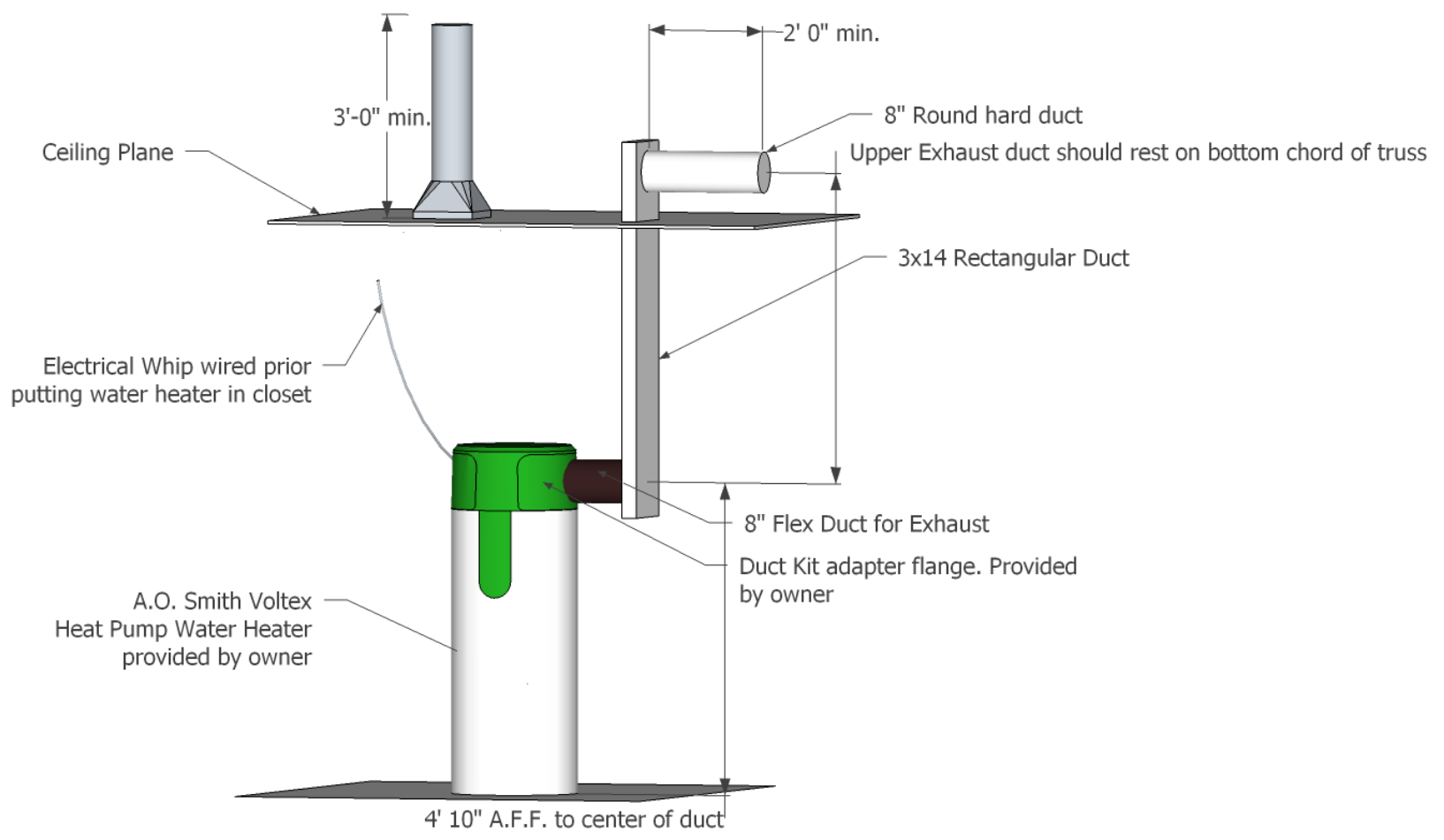

Figure 25. Rendering of LaFayette HPWH critical dimensions 

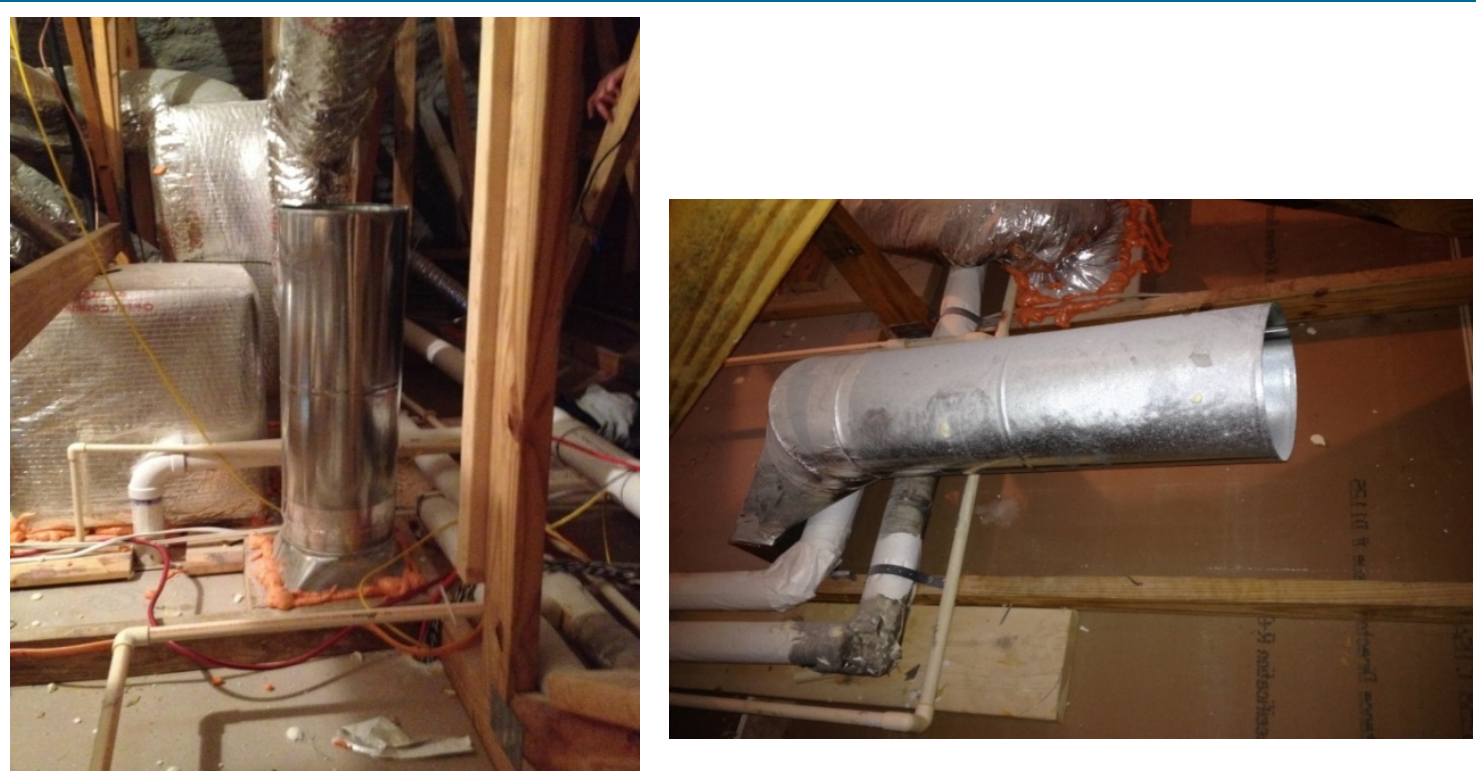

Figure 26. Vertical intake transfer duct connects to a vent in the mechanical closet's ceiling (left); horizontal exhaust duct connects to 3 -in. $\times 14$-in. rectangular duct inside the wall cavity leading to the HPWH in closet (right).

The test home in Savannah Gardens had an HPWH installed directly in the ocSPF encapsulated attic $\left(\sim 1,508 \mathrm{ft}^{3}\right)$ with a 10-ft duct terminating therein (Figure 27$)$. The house adjacent to the test home is of similar size, dimension, and construction, with an electric 50-gal A.O. Smith water heater (ECRT-52) in its encapsulated attic. The temperature and relative humidity in the attic of the neighboring home were also monitored.

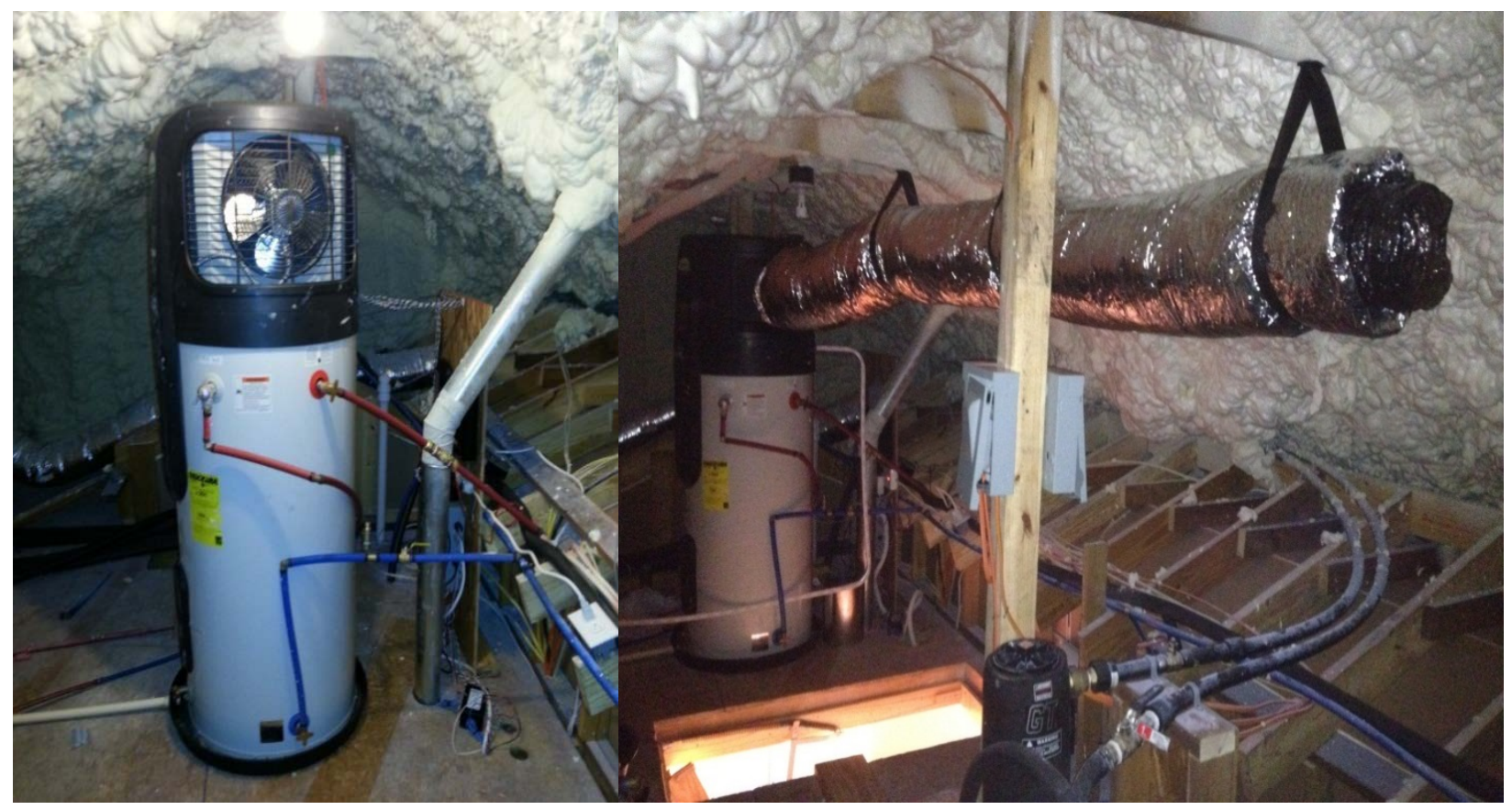

Figure 27. Savannah Gardens Lot 207 HPWH in the encapsulated attic before the exhaust duct was installed (left) and after the exhaust duct was installed (right) 


\subsection{Performance Testing Results}

An envelope leakage (blower door) test was performed on each building, and duct leakage tests were performed at Savannah Gardens and JMC Patrick Square. The results are reported in Table 8 .

Table 8. Test Home Performance Testing Results

\begin{tabular}{c|c|c|c}
\hline Test Home & $\begin{array}{c}\text { Airtightness } \\
\left(\mathbf{A C H}_{\mathbf{5 0}}\right)\end{array}$ & $\begin{array}{c}\text { Total Duct } \\
\text { Leakage } \\
\left(\mathbf{C F M}_{\mathbf{2 5}}\right)\end{array}$ & $\begin{array}{c}\text { Duct Leakage } \\
\text { to Outside } \\
\left(\mathbf{C F M}_{\mathbf{2 5}}\right)\end{array}$ \\
\hline Savannah Gardens & 1.9 & $65(5.4 \%)$ & 0 \\
JMC Patrick Square & 2.5 & $87(4.8 \%)$ & 0 \\
LaFayette & 2.1 & $\mathrm{n} / \mathrm{a}$ & 0 \\
\hline
\end{tabular}

The exclusive use of ocSPF for roof and wall cavity insulation was considered at LaFayette to ensure tight envelopes but was not used in wall cavities due to budget constraints. Concerns about the impact on envelope air leakage of using Spider instead of ocSPF in the wall cavities proved unfounded. Blower door testing done as the homes were nearing completion showed that nearly every apartment was lower than the target of $3.3 \mathrm{ACH}_{50}$; a few units were lower than 2.0 $\mathrm{ACH}_{50}$. Figure 28 shows the variations of envelope leakage in all units by number of bedrooms. The two two-bedroom units in the Uniform Federal Accessibility Standards building are the outliers in the data. All the other buildings' layouts were two- and three-bedroom duplexes. The front-facing bedrooms in the outlying duplex have dormers that were not specifically detailed for air sealing and insulation, and some sort of sealing was clearly omitted from these two twobedroom units. Although they still easily exceeded 2009 International Energy Conservation Code infiltration rates $\left(7 \mathrm{ACH}_{50}\right)$, one unit narrowly missed ENERGY STAR Version 3 infiltration levels $\left(5 \mathrm{ACH}_{50}\right)$. All the three-bedroom units met the 2012 International Energy Conservation Code requirements $\left(3 \mathrm{ACH}_{50}\right)$. LaFayette also had guarded blower door tests performed on two duplex buildings to distinguish envelope leakage to the outside from that to the adjacent unit. Approximately $35 \%$ of the total leakage was to the adjacent unit. 
Blower Door Tests

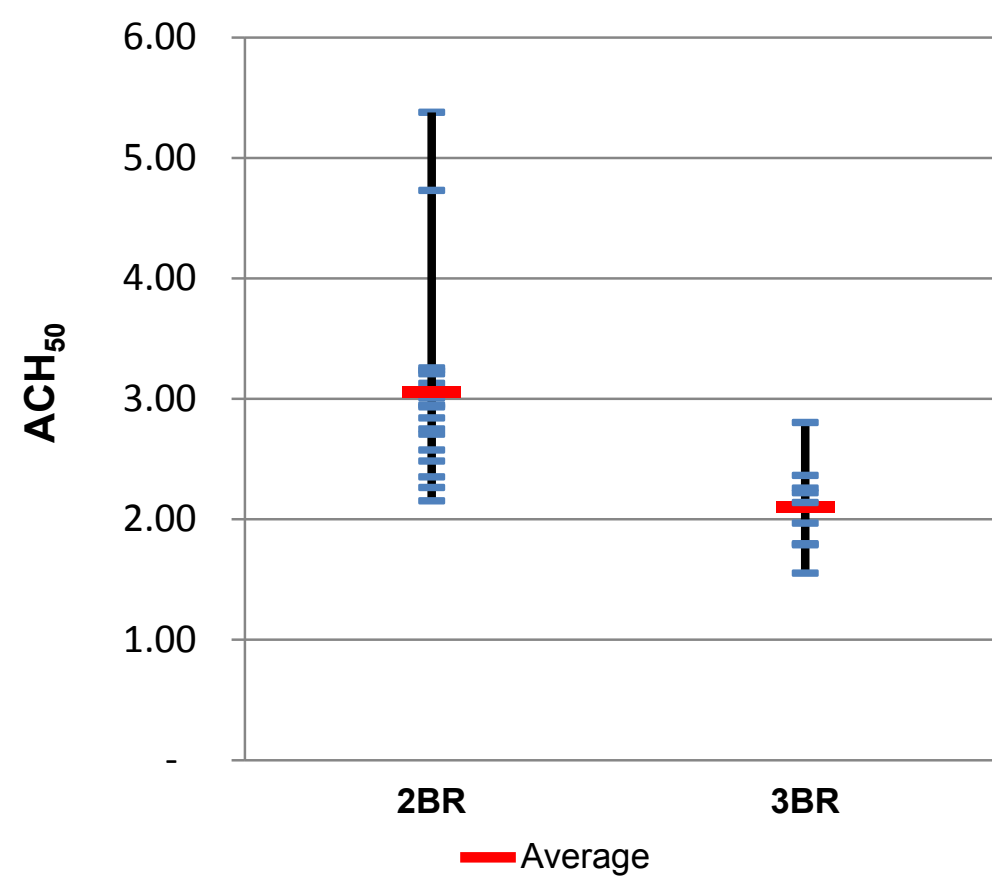

Figure 28. LaFayette airtightness values. Data Courtesy of SKCollaborative. ${ }^{3}$

JMC Patrick Square had the greatest envelope leakage of all three homes, and an infrared camera was used to identify major air leakage pathways. Large sources of air leakage were identified in the attic where the ocSPF did not make an airtight seal between the bases of the trusses and the wall top plates (Figure 29) and behind the bathtub in the master suite (Figure 30).

\footnotetext{
${ }^{3}$ See http://www.skcollaborative.com/.
} 


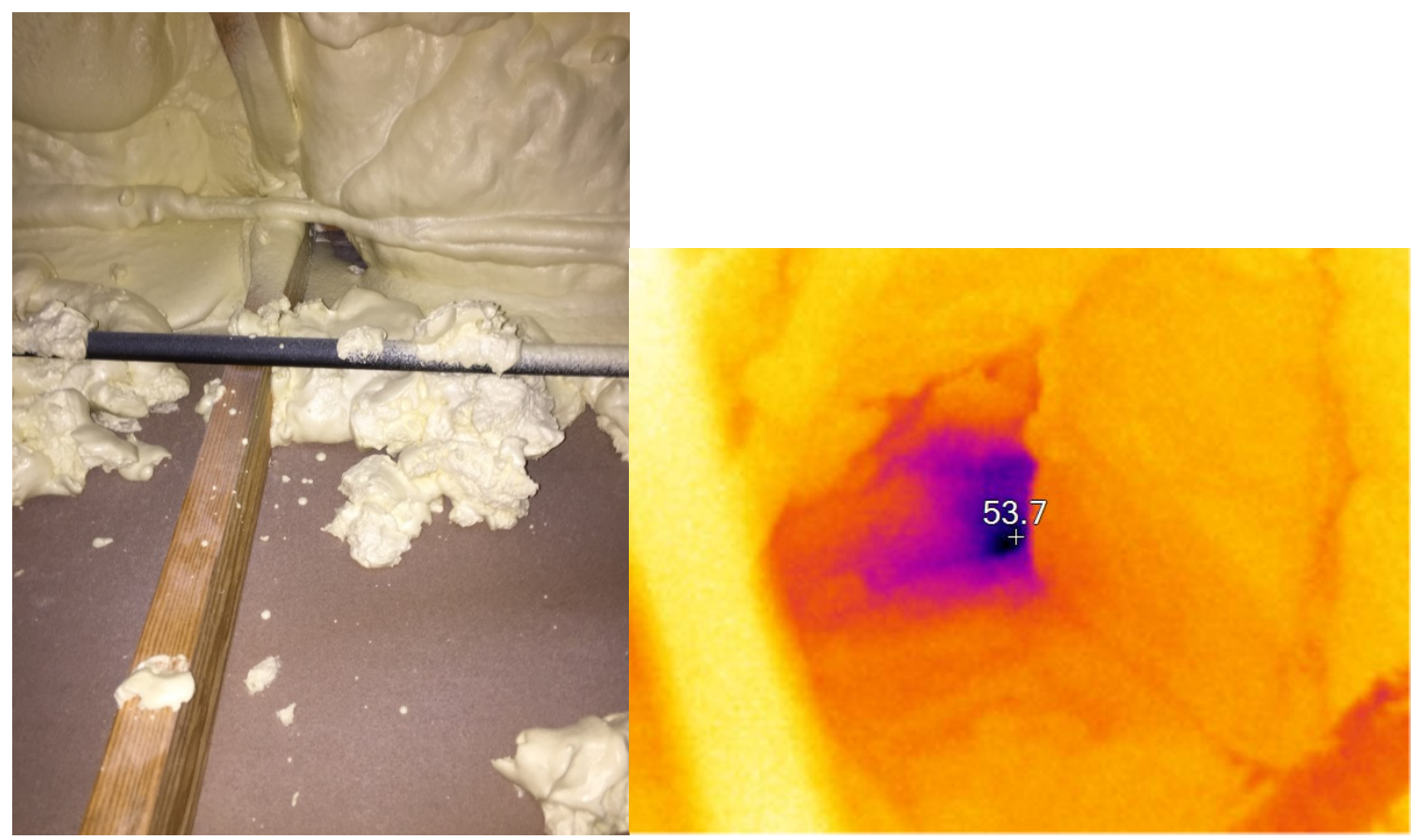

Figure 29. Attic air leakage pathways identified in ocSPF at truss-to-top plate intersection

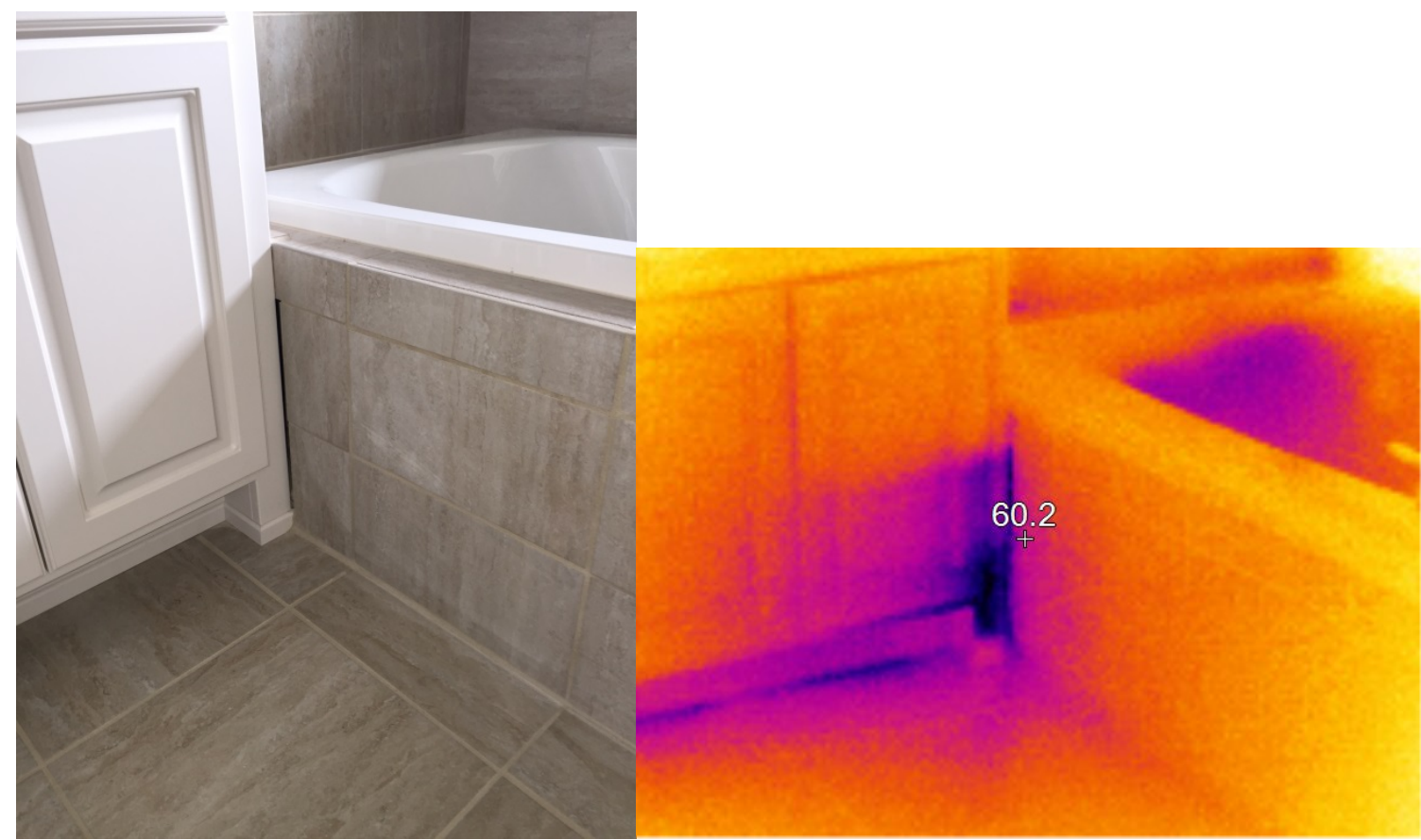

Figure 30. Attic air leakage pathways identified around master bathtub 


\section{Monitoring Analyses and Results}

\subsection{Ducted Heat Pump Water Heaters}

This study analyzed five 60-gal A.O. Smith Voltex HPWHs (model PHPT-60): four installed at LaFayette and one at Savannah Gardens. Both test sites had ocSPF rooflines to create encapsulated attics. The efficiency mode (heat pump only; no electric resistance assistance) was of primary interest in this study because the affordable housing providers were motivated to minimize occupant utility expenses and ensure that hot water demand was met. The PHPT series can be ducted (maximum of $10 \mathrm{ft}$ ) to another zone when the free air volume of the occupied zone is less than $750 \mathrm{ft}^{3}$ (A.O. Smith, 2011, 2012). Inlet and outlet duct kits, which are identical, are available from the manufacturer and enable multiple ducting configurations.

A previous Building America field monitoring study was conducted on both the 60- and 80-gal A.O. Smith Voltex HPWHs by Steven Winter Associates (Shapiro and Puttagunta 2013). The authors reported COP values of 2.1 for both model sizes operating in hybrid mode. The 80 -gal unit did not use the electric resistance elements, but $11 \%$ of the 60 -gal unit's energy consumption was from the electric resistance elements. They also reported an efficiency reduction of $16 \%$ (COP 1.76) for installations in confined spaces. Preliminary results of this investigation of reduced performance in confined spaces indicated that the ducted HPWHs at both sites performed comparably to other studies (Amarnath and Bush 2012; Ecotope Inc and Northwest Energy Efficiency Alliance 2015; Larson and Bedney 2011). Also, A.O. Smith recommended that these not be operated unducted in the mechanical closets; thus, no unducted HPWHs were tested.

Southface adhered to NREL's Field Monitoring Protocol for HPWHs (Sparn et al. 2013) to collect valuable data on in-situ ducted HPWHs to add to the limited field-monitored data and serve as a reference point for the refinement of HPWH computational models.

The HPWHs were installed by local plumbing tradesmen at each site whose HPWH training consisted of a 30-minute installation video provided by A.O. Smith. The ducts were installed by local HVAC tradesmen and commissioned by Southface for an extra cost of $\$ 250-\$ 300$ /unit at the LaFayette site. The only installation issue to date specific to HPWHs was that the plumber installed a condensation drainpipe to only one of the two condensation drains at the Savannah site.

\subsubsection{Monitoring Equipment and Uncertainty Analysis}

The following monitoring equipment was installed (Table 9):

Table 9. Monitoring Equipment and Purpose

\begin{tabular}{c|c|c|c}
\hline $\begin{array}{c}\text { Parameter of } \\
\text { Interest }\end{array}$ & Monitor Type & Purpose & Accuracy \\
\hline $\begin{array}{c}\text { Btu Hot } \\
\text { Water } \\
\text { Delivered }\end{array}$ & $\begin{array}{c}\text { Badger In-line } \\
\text { Btu meter }\end{array}$ & $\begin{array}{c}\text { Measures temperatures of cold } \\
\text { water supply and hot water outlet } \\
\text { lines and flow rate at the water } \\
\text { heater. }\end{array}$ & $\begin{array}{c} \pm 0.3^{\circ} \mathrm{C}, \pm 2 \% \text { of } \\
\text { flow rates } \\
\text { above } 1.65 \\
\text { GPM }\end{array}$ \\
\hline
\end{tabular}




\begin{tabular}{|c|c|c|c|}
\hline $\begin{array}{l}\text { Parameter of } \\
\text { Interest }\end{array}$ & Monitor Type & Purpose & Accuracy \\
\hline $\begin{array}{c}\text { Power } \\
\text { Consumption }\end{array}$ & $\begin{array}{l}\text { Trendpoint } \\
\text { EnerSure }\end{array}$ & $\begin{array}{l}\text { Power meter capable of reading } \\
\text { multiple current transducers to } \\
\text { monitor total electricity } \\
\text { consumption and component-level } \\
\text { power of the HPWH. }\end{array}$ & $\pm 1 \%$ \\
\hline $\begin{array}{l}\text { Duct Air } \\
\text { Temperature } \\
\text { and Humidity }\end{array}$ & $\begin{array}{l}\text { Vaisala in-duct } \\
\text { temperature and } \\
\text { humidity probe }\end{array}$ & $\begin{array}{l}\text { Measure the temperature and } \\
\text { humidity of the air stream within } \\
\text { the duct just before air enters and } \\
\text { just after the air leaves the HPWH. }\end{array}$ & $\begin{array}{l} \pm 0.3^{\circ} \mathrm{C} \\
\pm 3 \% \text { relative } \\
\text { humidity }\end{array}$ \\
\hline $\begin{array}{l}\text { Attic and } \\
\text { Room } \\
\text { Temperature } \\
\text { and Humidity }\end{array}$ & $\begin{array}{c}\text { OmniSense } \\
\text { wireless } \\
\text { temperature and } \\
\text { relative } \\
\text { humidity } \\
\text { sensors } \\
\end{array}$ & $\begin{array}{l}\text { Measure changes in temperature } \\
\text { and humidity to determine the } \\
\text { impact of the HPWH on attic and } \\
\text { occupied space conditions. }\end{array}$ & $\begin{array}{l} \pm 0.4^{\circ} \mathrm{C} \\
\pm 3.5 \% \text { relative } \\
\text { humidity }\end{array}$ \\
\hline
\end{tabular}

An uncertainty analysis was performed by propagating the error of each sensor measurement used for calculating COP. Sensor accuracies are listed in Table 3. First, the uncertainty of $\Delta \mathrm{T}_{\text {draws }}$ was calculated using the following equation.

$$
\delta \Delta T=\sqrt{\left(\delta T_{\text {out }}\right)^{2}+\left(\delta T_{\text {in }}\right)^{2}}
$$

The uncertainty of $\Delta \mathrm{T}_{\text {draws }}$ was calculated to be $\pm \sqrt{0.18}$. Total COP uncertainty can be approximated using the following equation.

$$
\frac{\delta C O P}{C O P}= \pm \sqrt{\left(\frac{\delta V_{\text {draws }}}{V_{\text {draws }}}\right)^{2}+\left(\frac{\delta W_{\text {input }}}{W_{\text {input }}}\right)^{2}+\left(\frac{\delta \Delta T_{\text {draws }}}{\Delta T_{\text {draws }}}\right)^{2}}
$$

Total COP uncertainty was determined to be $\pm 3.1 \%$. An example uncertainty for daily parameters is shown in Table 10.

Table 10. Uncertainty for Example Daily Values

\begin{tabular}{c|c|c}
\hline Metric & $\begin{array}{c}\text { Daily } \\
\text { Value }\end{array}$ & $\begin{array}{c}\text { Daily } \\
\text { Uncertainty }\end{array}$ \\
\hline COP & 2.4 & \pm 0.07 \\
Daily $\mathbf{V}_{\text {draws }}$ (gal) & 47.8 & \pm 1.0 \\
Daily $\left.\Delta \mathbf{T}_{\text {draws }}{ }^{\circ} \mathbf{C}\right)$ & 22.7 & \pm 0.3 \\
Daily $\mathbf{W}_{\text {input }}(\mathbf{k W h})$ & 2.8 & \pm 0.03 \\
\hline
\end{tabular}

\subsubsection{Heat Pump Water Heater Performance Results}

Ducted HPWH results were calculated at all LaFayette sites (A, B, C, and D) from February 2014 to January 2015. In Savannah, the HPWH was apparently turned to vacation mode for several days while the homeowners were still at home and using "hot" water at a normal rate. In 
response, the HPWH was then set to the highest set point available, $150^{\circ} \mathrm{F}$. The time periods with $120^{\circ} \mathrm{F}$ and $150^{\circ} \mathrm{F}$ set points were analyzed separately (E1 and E2). When averaging the daily COP calculations, equal weight was given to each daily COP value. Average daily COP values for a $120^{\circ} \mathrm{F}$ tank set point at the LaFayette site ranged between 1.9 and 2.5; COP was 3.1 at the Savannah site. This average gives equal weight to each day, regardless of hot water consumed, so the COP across the entire monitored period was calculated and resulted in slightly different COP values at each site. As expected, raising the set point resulted in lowering the COP in Savannah. It also resulted in a decrease in total hot water drawn, because less of the hotter water is needed when mixed with cold water to achieve the same desired temperatures at the tap. These results and the daily average values of variables used in the COP calculation are listed in Table 11.

Table 11. Summary of All Monitored HPWH Daily Average Variables Used To Compute Daily Average COP

\begin{tabular}{c|c|c|c|c|c|c|c}
\hline Site & $\begin{array}{c}\text { Water } \\
\text { Heater Set } \\
\left.\text { Point } \mathbf{(}^{\circ} \mathbf{F}\right)\end{array}$ & $\begin{array}{c}\text { Avg. Daily } \\
\text { DHW Use } \\
(\text { gal) }\end{array}$ & $\begin{array}{c}\text { Avg. } \\
\text { Cold } \\
\text { Water } \\
\text { Temp } \\
\left.\mathbf{(}^{\circ} \mathbf{F}\right)\end{array}$ & $\begin{array}{c}\text { Avg. } \\
\text { Hot } \\
\text { Water } \\
\text { Temp } \\
\left({ }^{\circ} \mathbf{F}\right)\end{array}$ & $\begin{array}{c}\text { Avg. Daily } \\
\text { HPWH } \\
\text { Electric } \\
\text { Use } \\
(\mathbf{k W h})\end{array}$ & $\begin{array}{c}\text { Avg. } \\
\text { Daily } \\
\text { COP }\end{array}$ & $\begin{array}{c}\text { Average } \\
\text { COP }^{\text {a }}\end{array}$ \\
\hline A & 120 & 76.5 & 68.3 & 111.0 & 3.1 & 2.5 & 2.6 \\
\hline B & 120 & 27.1 & 71.5 & 110.2 & 1.4 & 1.9 & 2.0 \\
\hline C & 120 & 55.1 & 71.1 & 111.5 & 2.4 & 2.2 & 2.4 \\
\hline D & 120 & 41.6 & 70.7 & 109.2 & 1.9 & 2.0 & 2.2 \\
\hline E1 & 120 & 76.6 & 77.7 & 113.5 & 2.2 & 3.1 & 3.0 \\
\hline E2 & 150 & 55.5 & 75.2 & 128.8 & 3.7 & 2.0 & 1.9 \\
\hline
\end{tabular}

${ }^{\mathrm{a}}$ Average COP was calculated across the entire time period.

Because both intake and exhaust ducting is available, the researchers varied the ducting configurations at LaFayette to determine whether they impacted HPWH performance. To compare HPWH performance under different ducting configurations, variables were analyzed for equivalent durations directly before and after the duct configuration changes. Table 12 documents the date ranges of the HPWH duct configurations and the corresponding average daily COP values. All units began with the standard exhaust duct strategy during Time 1; during Time 2, Units A and B were subjected to variations. The COP values remained the same for all three units, even though the ducting configurations for Units $\mathrm{A}$ and $\mathrm{B}$ changed. Unit $\mathrm{C}$ was left with its original ducting to verify that the COP would not change. 
Table 12. Date Ranges of Each Site and the Duct Configuration Applied

\begin{tabular}{|c|c|c|c|c|c|c|c|}
\hline Site & Location & $\begin{array}{c}\text { Time } 1 \\
8 / 26-9 / 16\end{array}$ & $\begin{array}{c}\text { Time } 1 \\
\text { Avg. Daily } \\
\text { DHW Use } \\
\text { (gal) }\end{array}$ & $\begin{array}{c}\text { Time } 1 \\
\text { Avg. } \\
\text { Daily } \\
\text { COP }\end{array}$ & $\begin{array}{c}\text { Time } 2 \\
\text { 9/18-10/19 }\end{array}$ & $\begin{array}{c}\text { Time } 2 \\
\text { Avg. Daily } \\
\text { DHW Use } \\
\text { (gal) }\end{array}$ & $\begin{array}{c}\text { Time } 2 \\
\text { Avg. } \\
\text { Daily } \\
\text { COP }\end{array}$ \\
\hline \multirow[t]{2}{*}{$\mathbf{A}$} & Intake & & \multirow{2}{*}{82.7} & \multirow{2}{*}{2.5} & $X^{a}$ & \multirow{2}{*}{86.9} & \multirow{2}{*}{2.5} \\
\hline & Exhaust & $\mathrm{X}$ & & & $X$ & & \\
\hline \multirow[t]{2}{*}{ B } & Intake & & \multirow{2}{*}{27.4} & \multirow{2}{*}{1.8} & X & \multirow{2}{*}{29.8} & \multirow{2}{*}{1.8} \\
\hline & Exhaust & X & & & & & \\
\hline \multirow[t]{2}{*}{ C } & Intake & & \multirow{2}{*}{64.7} & \multirow{2}{*}{2.3} & & \multirow{2}{*}{52.5} & \multirow{2}{*}{2.3} \\
\hline & Exhaust & X & & & X & & \\
\hline
\end{tabular}

${ }^{\mathrm{a}}$ Indicates the location was ducted if the intake or exhaust was ducted.

Figure 31 displays the trend between daily hot water consumption and average daily COP. The COP increases sharply before reaching the knee of the curve between 20 and $40 \mathrm{gal} /$ day before leveling. This trend was reported by Shapiro and Puttagunta (2013). They reported an average COP value of 2.1 for the unducted A.O. Smith Voltex models; the average of daily averages for all units in this study was 2.3 (excluding E2).

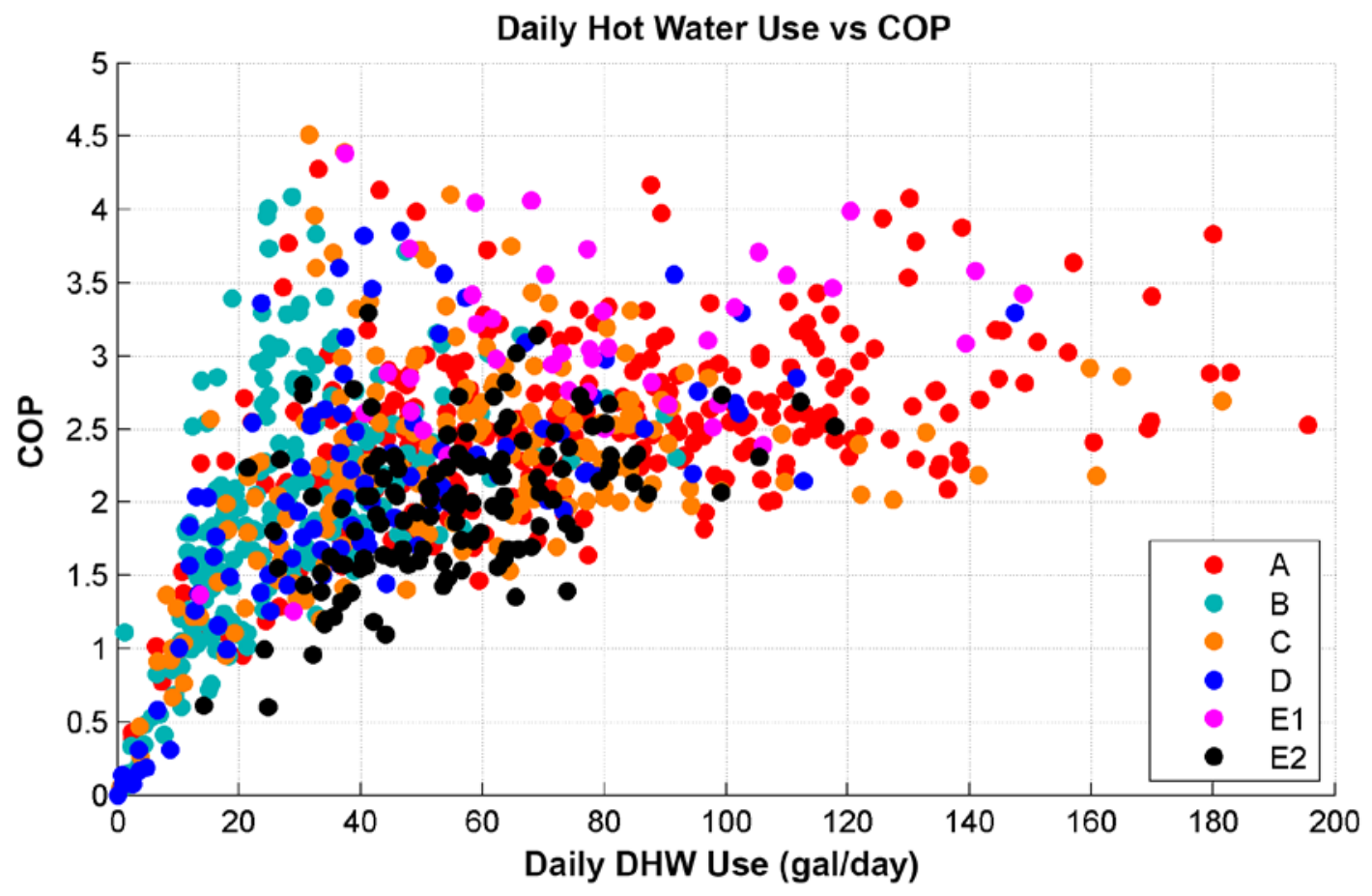

Figure 31. Scatter plot of daily hot water use versus COP for all five units

\subsubsection{Impact on Encapsulated Attic Air Temperature and Humidity}

One of the research questions was what impact the exhaust air of the HPWH has on the HVAC loads of living space. Temperature and humidity sensors placed in the attics of the DOE Challenge Home (Test Unit E), currently known as Zero Energy Ready, plus the neighboring home (Test Unit F) in Savannah provide a good basis for comparison. Large diurnal swings in 
absolute and relative humidity were observed in the attics of all six monitored test homes (four in LaFayette and two in Savannah). The fluctuations of the absolute humidity levels in the attics are believed to be highly influenced by the "sponge" effect of ocSPF rooflines, which is due to moisture loads driven in and out of the foam and roof structure by solar heating and night cooling (Boudreaux, Pallin, and Jackson 2014). The moisture levels in the sealed attics at all six sites show similar daily moisture levels throughout the year. Under the current operation regime, the HPWH does not appear to remove enough moisture each day to make significant reductions in daily peak moisture loads compared to the adjacent house with a standard electric water heater (Figure 32). HPWH operation also has minimal impact on interior living zone humidities. Further monitoring and research is needed to better understand this effect and to develop strategies that effectively reduce moisture levels in sealed attics of low-load homes. One potential HPWH operating regime would be to introduce more complex control strategies such as increased morning set points or "learning" logic.

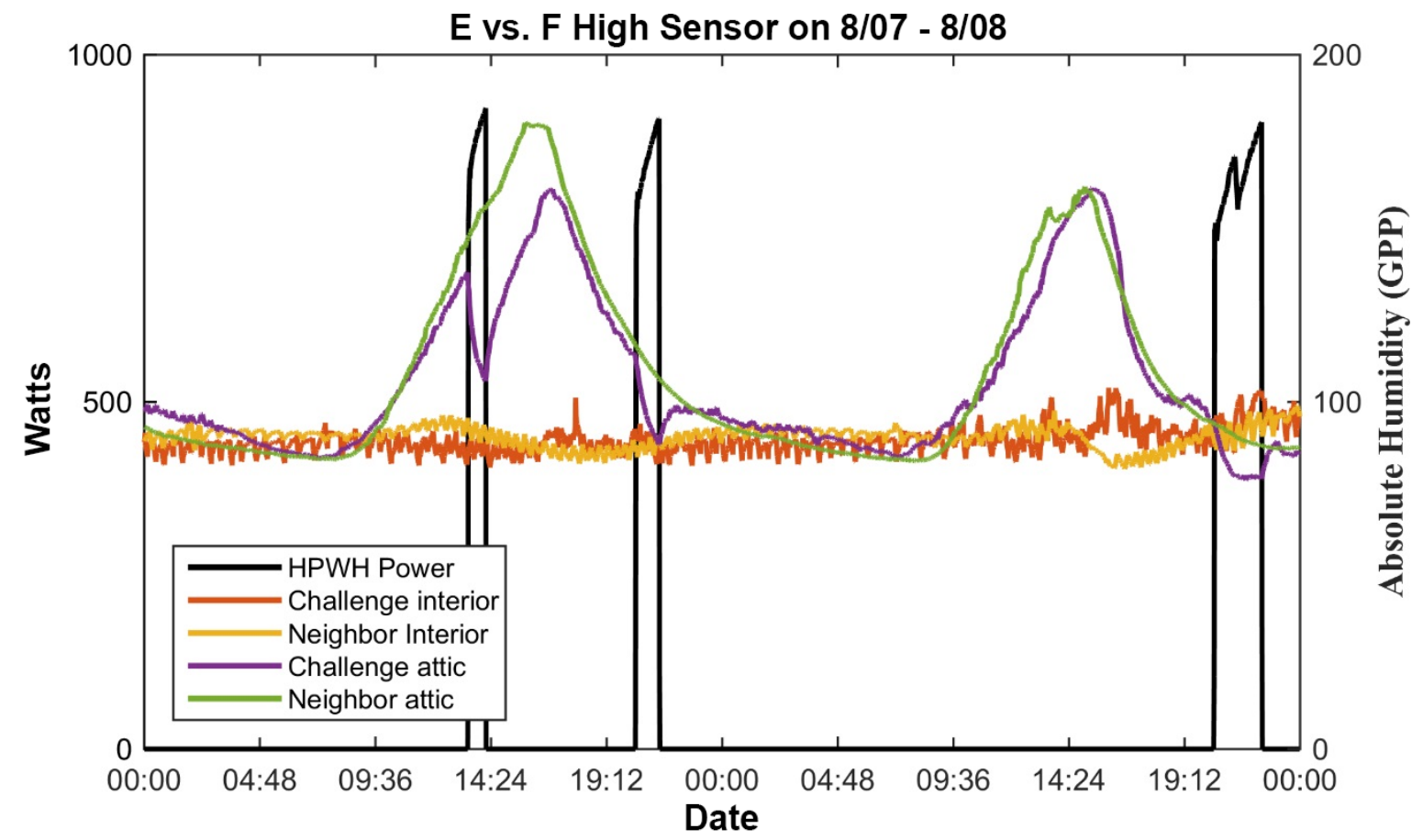

Figure 32. Savannah Unit $E$ and Unit $F$ absolute humidities at the high center locations of the attic and the living spaces

Attic temperatures were monitored in four locations (north, south, and east sides of the house and high center of the attic about 6 feet from the attic floor) (Figure 33). The temperatures decreased when the HPWH operated during the end of the day, but whether the HPWH operation or the sun setting caused this decrease is difficult to distinguish. During the first half of the day attic temperatures rose due to the sun rising. In one instance, the HPWH operated during the first half of the day and the east side, where the duct pointed, decreased by less than $2^{\circ} \mathrm{F}$. The north and south sensor readings decreased by less than $0.4^{\circ} \mathrm{F}$. The sensor at the high center of the attic continued to increase while the HPWH operated. Figure 34 shows a zoomed in image of the temperatures during this time. Because the HPWH was able to reduce the attic temperature in 
only one area of the attic, the HPWH likely had no impact on the temperature in the living zone or the energy consumed by the HVAC equipment.

\section{A: Attic Air Temperatures}

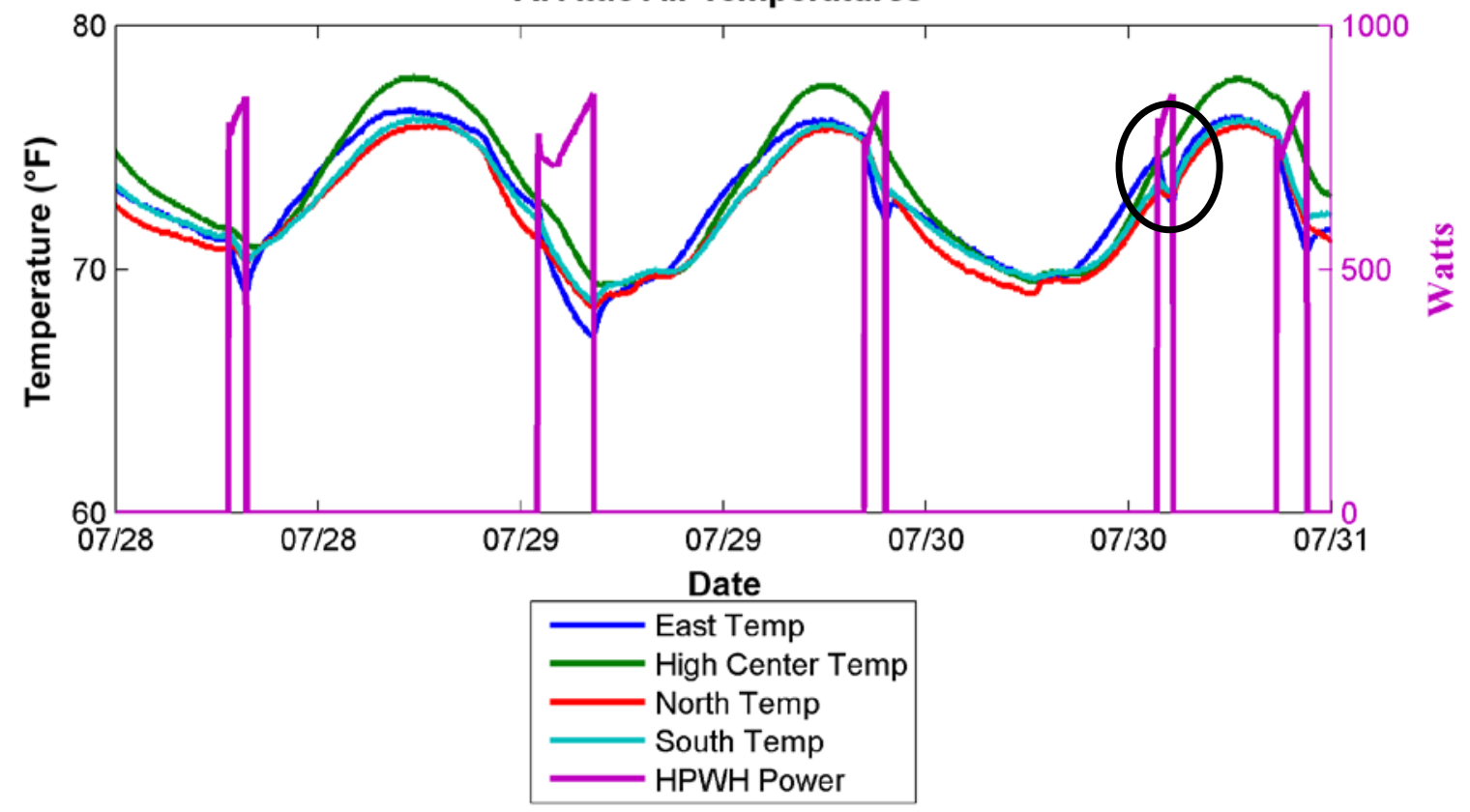

Figure 33. Attic temperatures at five locations around the attic during the summer at LaFayette Site $\mathrm{E}$. The circled area can be seen in zoom in Figure 34.

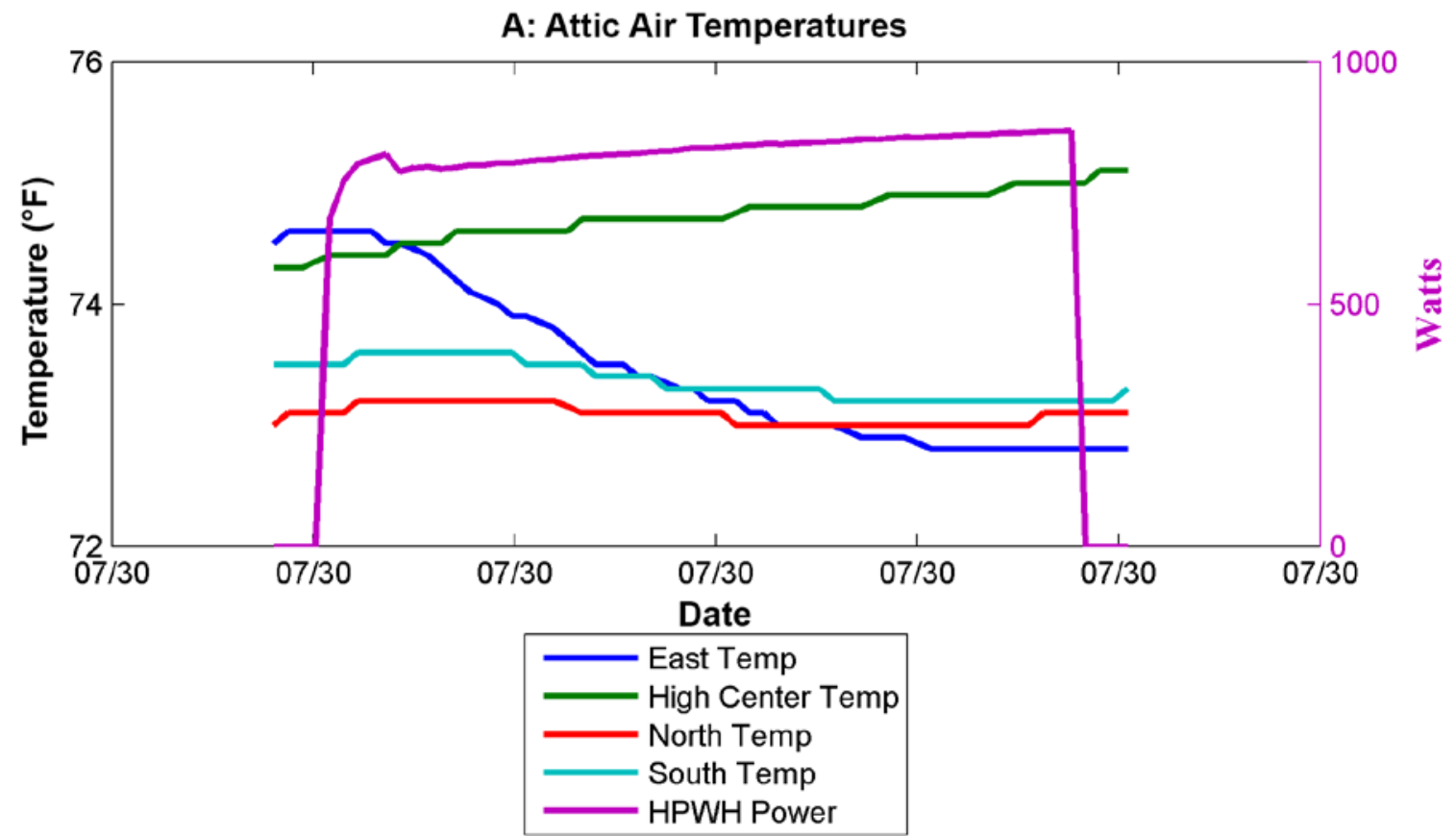

Figure 34. Zoomed section of Figure 33 showing attic temperature changes during HPWH operation 


\subsection{Huber Zip System Sheathing Performance}

In-situ field measurements of wall temperature, relative humidity, and wood moisture content data were analyzed to compare the ZipR wall assembly performance of the Savannah Gardens test home to the neighboring home with traditional uninsulated Zip. All measurements were recorded with OmniSense sensors (see specifications in Table 9).

\subsubsection{Wall Monitoring Plan}

Seventeen sensors were installed inside the Zip and ZipR wall assemblies, and an additional sensor was installed in each home near the thermostat. The sensors inside the walls were placed in three positions: (A) flush mount to oriented strand board, (B) legs through Zip foam to oriented strand board and $(\mathrm{C})$ stud side near the drywall. The locations of the sensors are depicted in Figure 35, images of the sensors in the wall assemblies are shown in Figure 36, and a vertical cross section schematic is shown in Figure 37.

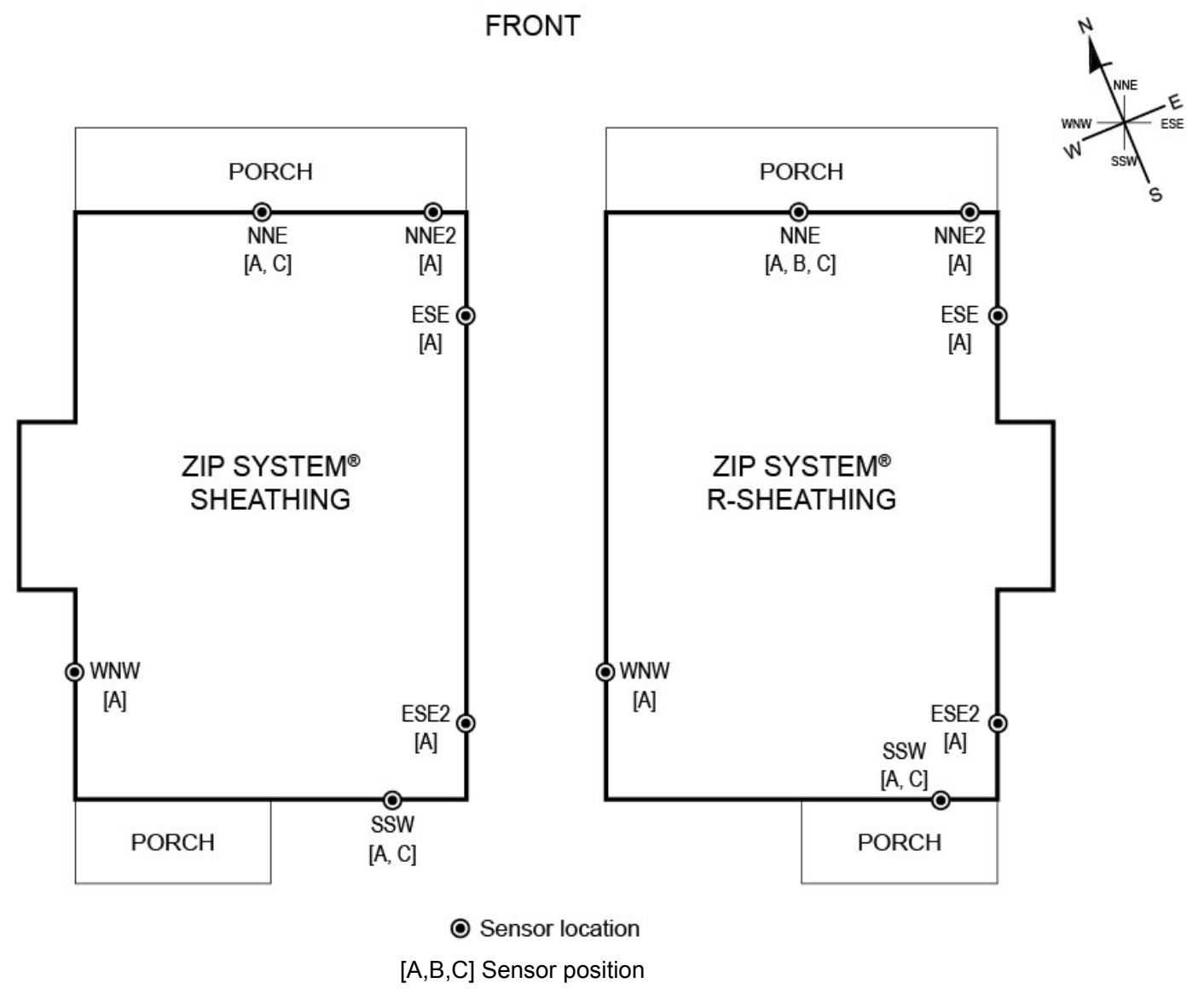

Figure 35. OmniSense sensor locations and positions in Zip and ZipR test homes 


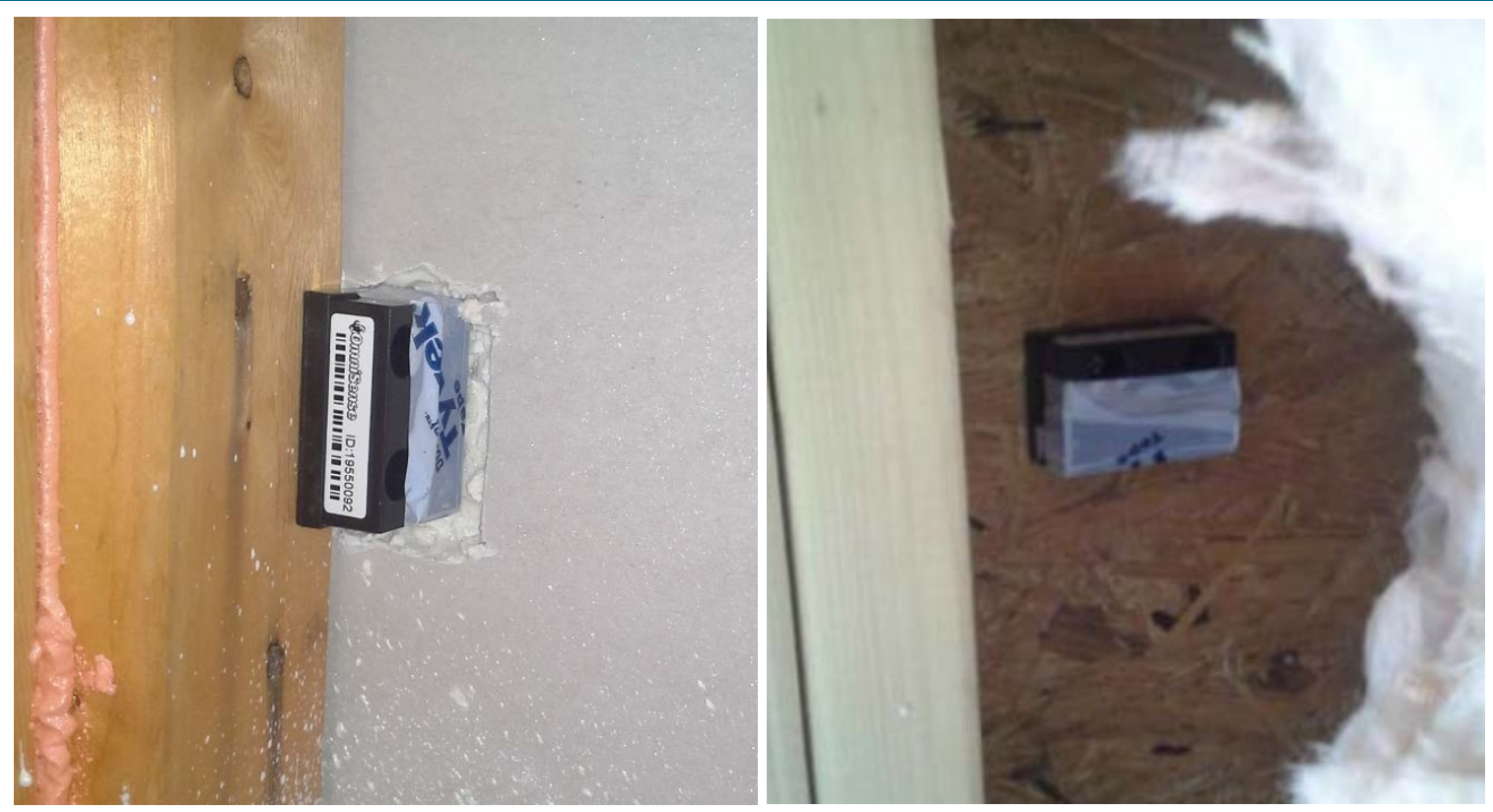

Figure 36. OmniSense sensor position A in ZipR home (left); Zip home (right)
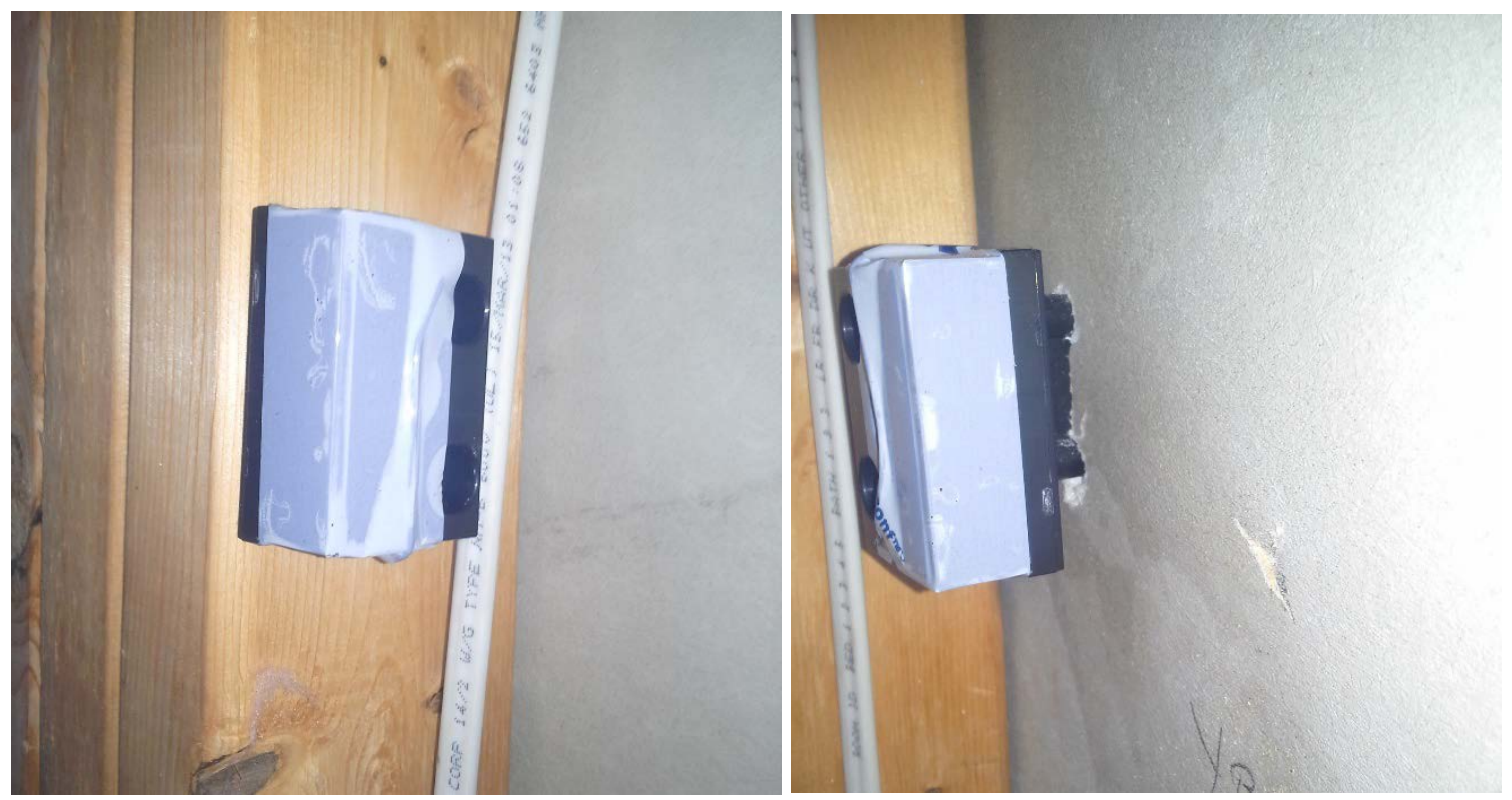

Figure 37. OmniSense sensor position C (left); position B (right) 


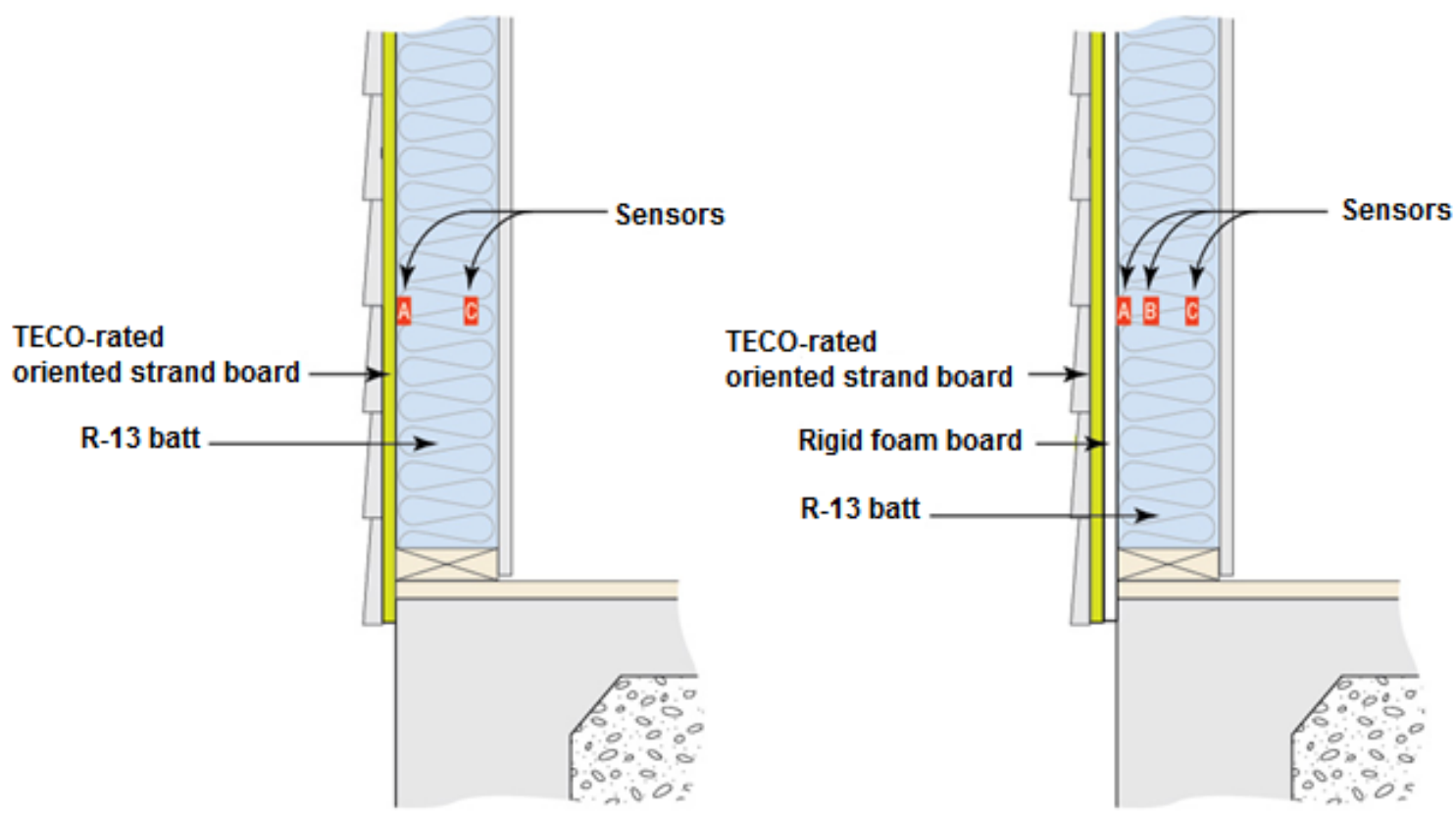

Figure 38. OmniSense sensor location and position in Zip (left); ZipR (right) walls

\subsubsection{Wall Thermal Performance}

The amount of incident solar radiation depended on the wall orientation and level of shading. As seen in Figure 35, the fronts of both homes face the NNE orientation. The sensors in the middle of the NNE walls were fully covered by the front porches and received minimal solar exposure throughout the year. The homes provided shade for each other during certain time periods because of their proximity. The sun's low angle in the winter months limited the solar exposure of the Zip home's ESE wall due to shading from the ZipR home's WNW wall. Solar exposure varied dramatically with the SSW sensors due to back porch shading on the ZipR home.

Sensors on the WNW wall received similar solar exposure, and trends comparing a cloudy and sunny day were analyzed. Figure 39 shows the temperatures of the Zip and ZipR homes' WNW wall sheathing (position A) on Sept. 2 (a cloudy day) and Sept. 3 (a sunny day). The peak ambient temperatures for Sept. 2 and Sept. 3, 2014 were $92^{\circ} \mathrm{F}$ and $89^{\circ} \mathrm{F}$, respectively. The impact of incident solar radiation on the wall is evident on the second day by the drastic temperature increase. The Zip wall's peak temperature was $2.9^{\circ} \mathrm{F}$ higher than the ZipR's on the cloudy day and $7.8^{\circ} \mathrm{F}$ higher on the sunny day. This trend was observed throughout the summer months, and exposure to solar radiation magnified the difference in peak temperatures between the two wall assemblies. The ZipR WNW average daily peak was $3.4^{\circ} \mathrm{F}$ lower than the traditional Zip wall's daily peak temperature. The ZipR home's interior temperature was $2.2^{\circ} \mathrm{F}$ higher than the Zip. 


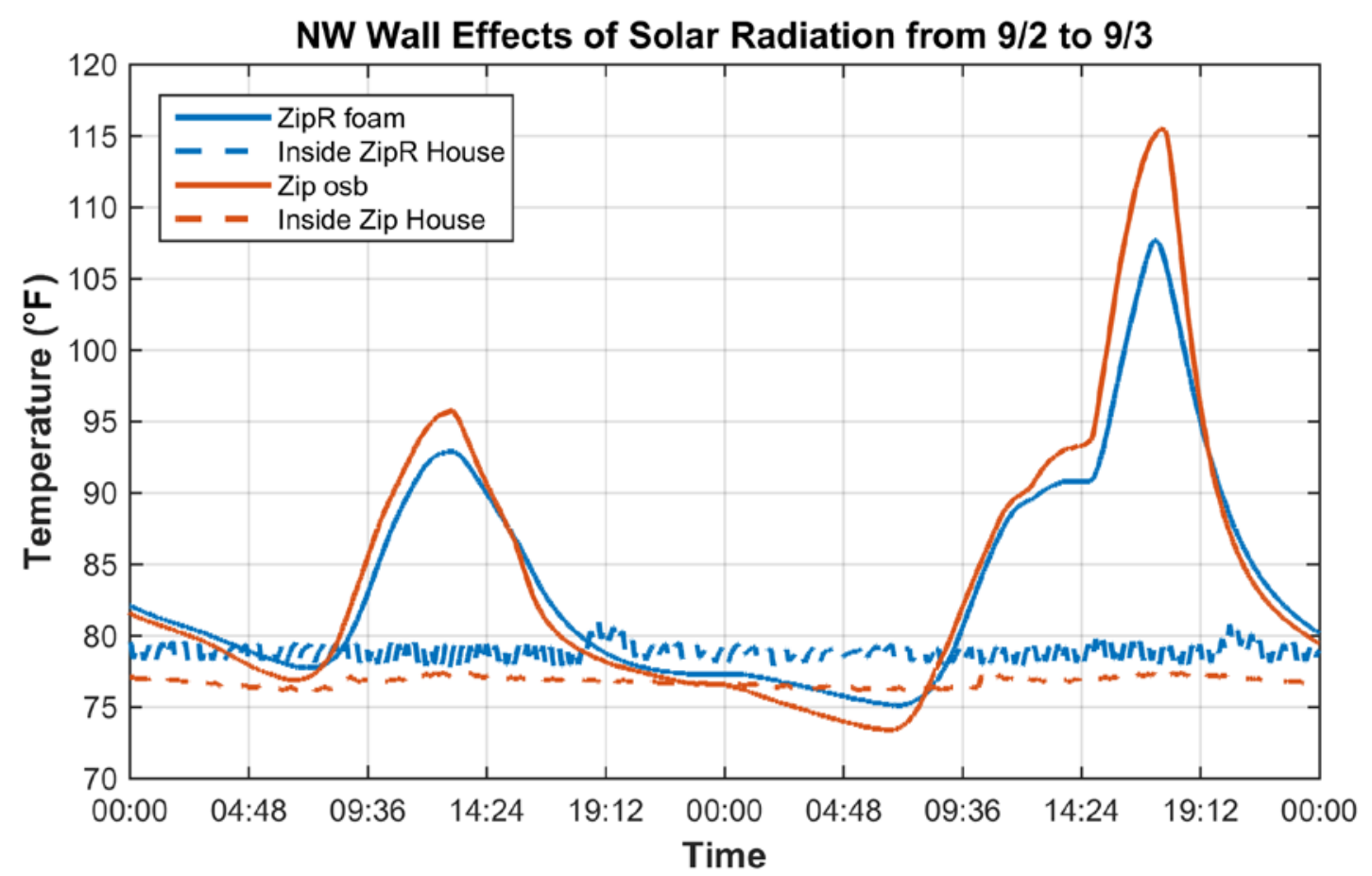

Figure 39. WNW wall temperatures on a cloudy (Sept. 2, 2014) and sunny (Sept. 3, 2014) day

Table 13 contains the WNW wall sheathing (position A) temperature summary for the summer and winter. During the summer, the difference between the Zip and ZipR maximum temperatures was calculated for each day and averaged across the period. The same calculation was performed during the winter for the daily minimum temperatures at each wall. The average interior temperature refers to the daily average temperature of the sensor inside the living space of the home. The temperature swing represents the average difference between daily maximum and minimum temperatures in the walls. The average ZipR WNW wall sheathing was $6.4^{\circ} \mathrm{F}$ warmer in the winter at its coldest point and $3.4^{\circ} \mathrm{F}$ cooler in the summer at its warmest compared to the Zip WNW wall sheathing. The ZipR wall experienced less severe daily temperature fluctuations, as exhibited by its lower daily temperature swing.

Table 13. ZipR and Zip WNW Wall Sheathing (Position A) Average Temperature Summaries for Heating and Cooling Seasons

\begin{tabular}{c|c|c}
\hline Average Daily Difference (ZipR - Zip) & Heating $^{\mathrm{a}}$ & Cooling $^{\mathrm{b}}$ \\
\hline Minimum Wall Temperature & $6.4^{\circ} \mathrm{F}$ & $\mathrm{N} / \mathrm{A}$ \\
Maximum Wall Temperature & $\mathrm{N} / \mathrm{A}$ & $-3.4^{\circ} \mathrm{F}$ \\
Average Interior Temperature & $-0.4^{\circ} \mathrm{F}$ & $2.2^{\circ} \mathrm{F}$ \\
\hline Temperature Swing & $-2.7^{\circ} \mathrm{F}$ & $-3.4^{\circ} \mathrm{F}$ \\
\hline
\end{tabular}

${ }^{a}$ December, January, February

${ }^{\mathrm{b}}$ July, August, September

Similar to the calculations above, the difference in daily maximum and minimum temperatures experienced by the NNE walls were calculated. Figure 40 illustrates the results. The first box plot shows the daily minimum temperature in the ZipR's NNE wall was on average $5.1^{\circ} \mathrm{F}$ 
warmer than the Zip's minimum temperature during the winter. During the summer, the NNE wall's daily maximum temperature was on average $0.4^{\circ} \mathrm{F}$ cooler in the ZipR home. The daily temperature range experienced by the NNE wall was greater in the Zip home 294 days of the 300 days of measured data.

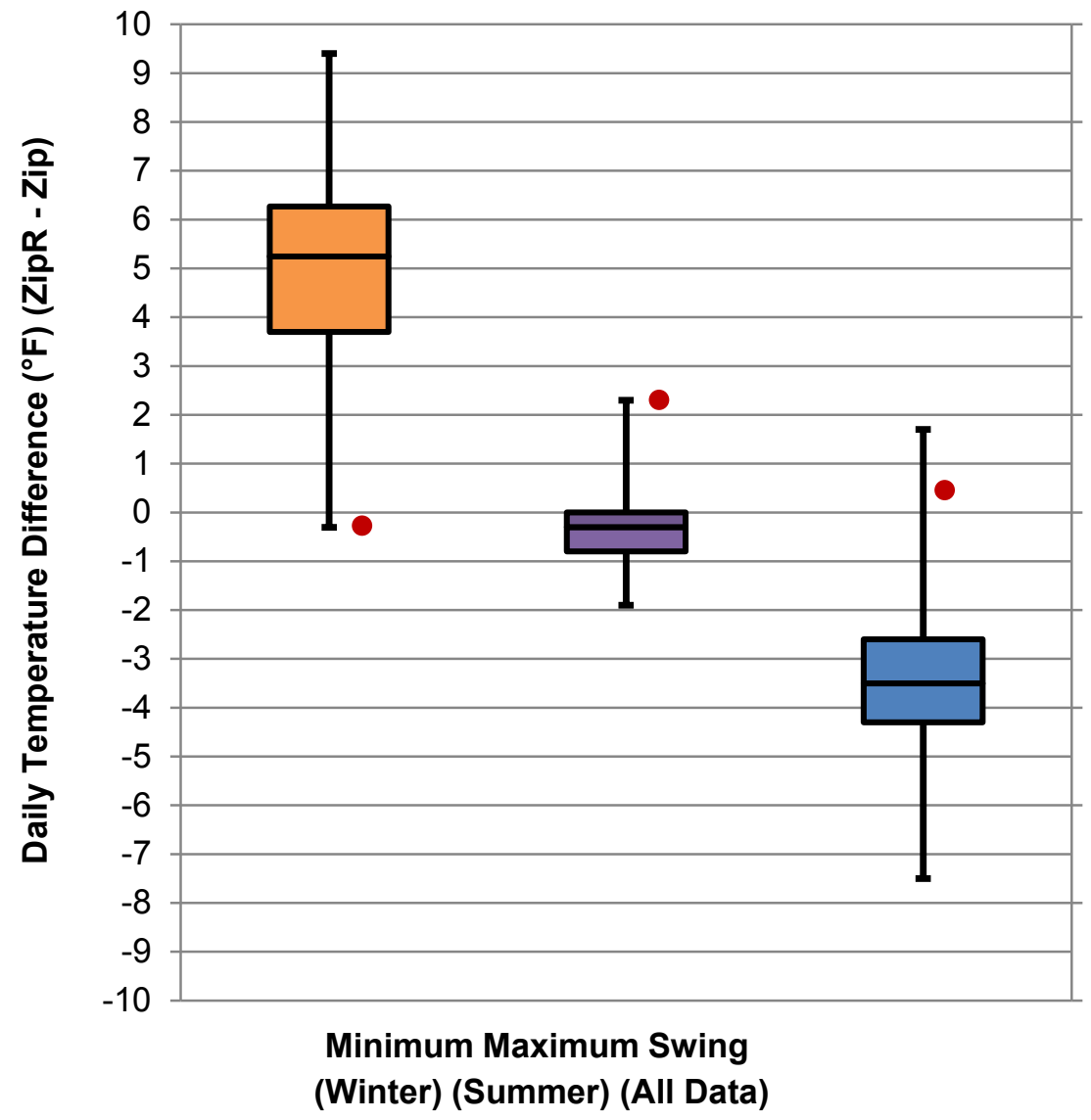

Average Daily Interior Temperature Difference (ZipR - Zip)

Figure 40. ZipR and Zip NNE wall daily temperature profile

The NNE wall temperature profile was also analyzed, because both homes' NNE walls received little solar exposure due to shading from the front porches. REM/Rate was used to calculate the clear-wall R-value for the walls with Zip and ZipR sheathing. Clear-wall R-value is the R-value of an assembly containing only insulation and minimum necessary framing materials at a clear section with no windows, corners, columns, architectural details, or interfaces with roofs, foundations or other walls. ${ }^{4} \mathrm{ZipR}$ sheathing increased the clear-wall R-value by $23 \%$ compared to the home with traditional Zip sheathing panels (assuming a $24 \%$ framing factor). ${ }^{5}$

\footnotetext{
${ }^{4}$ See http://buildingscience.com/glossary/clear-wall-r-value.

${ }^{5}$ See http://web.ornl.gov/sci/roofs+walls/research/detailed_papers/thermal_frame/.
} 
Table 14. Clear-Wall R-Value Comparison for Zip and ZipR Homes

\begin{tabular}{|c|c|c|c|c|}
\hline & \multicolumn{2}{|c|}{ ZipR Sheathing } & \multicolumn{2}{|c|}{ Zip Sheathing } \\
\hline Enclosure Component & $\begin{array}{c}\text { R-Value, } \\
\text { Cavity (ft }{ }^{2}{ }^{\circ} \mathbf{F} \\
\text { h/Btu) }\end{array}$ & $\begin{array}{l}\text { R-Value, } \\
\text { Stud (ft }{ }^{\circ} \text { F } \\
\text { h/Btu) }\end{array}$ & $\begin{array}{c}\text { R-Value, } \\
\text { Cavity (ft }{ }^{\circ}{ }^{\circ} \mathbf{F} \\
\text { h/Btu) }\end{array}$ & $\begin{array}{c}\text { R-Value, Stud } \\
\left(\mathrm{ft}^{2}{ }^{\circ} \mathrm{F} \mathrm{h} / \text { Btu }\right)\end{array}$ \\
\hline Outside Air Film & 0.28 & 0.28 & 0.28 & 0.28 \\
\hline $\begin{array}{l}\text { 7/16-in. Oriented } \\
\text { Strand Board }\end{array}$ & 0.60 & 0.60 & 0.60 & 0.60 \\
\hline 0.5-in. Rigid Insulation & 3.00 & 3.00 & 0.00 & 0.00 \\
\hline $2 \times 4$ Wood Stud & N/A & 4.38 & N/A & 4.38 \\
\hline 3.5-in. Fiberglass Batt & 13.00 & $\mathrm{n} / \mathrm{a}$ & 13.00 & $\mathrm{n} / \mathrm{a}$ \\
\hline 1/2-in. Dry Wall & 0.45 & 0.45 & 0.45 & 0.45 \\
\hline Interior Air Film & 0.82 & 0.82 & 0.82 & 0.82 \\
\hline $\begin{array}{c}\text { Total Assembly Clear- } \\
\text { Wall R-Value (23\% } \\
\text { Framing Factor) }\end{array}$ & \multicolumn{2}{|c|}{16.08} & \multicolumn{2}{|c|}{13.08} \\
\hline
\end{tabular}

Heating and cooling energy consumption was examined to determine the impact of the ZipR wall's ability to maintain warmer temperatures in the winter and cooler temperatures in the summer. Each home's heating and cooling is provided by a ground-source heat pump (GSHP). The GSHPs are identical and were installed by the same contractor. The GSHP runtimes were analyzed during a time when the indoor set points of both homes were similar. On Nov. 28, 2014, from 3:42 a.m. to 8:51 a.m., the average living zone temperature of both homes averaged $69.7^{\circ} \mathrm{F}$; the interior temperature difference varied by less than $0.2^{\circ} \mathrm{F}$. The GSHP on and off durations are reported in Table 15. The ZipR construction appears to lead to shorter runtimes, longer off times between GSHP runs, and less energy consumed ( $26 \%$ less).

Table 15. Zip and ZipR GSHP Runtimes

\begin{tabular}{|c|c|c|}
\hline & Zip Sheathing & ZipR Sheathing \\
\hline Number of GSHP Runs & 13 & 10 \\
\hline Average Duration of GSHP ON (min) & 10.2 & 9.7 \\
\hline Average Duration of GSHP OFF (min) & 13.3 & 19.7 \\
\hline Total Energy Consumption (kWh) & 3.10 & 2.28 \\
\hline
\end{tabular}

From Nov. 11, 2014 to Jan. 3, 2015, the Zip home's GSHP consumed 199.2 kWh and the ZipR home GSHP consumed $122.3 \mathrm{kWh}$, a 39\% decrease. During the same time, the sum of the absolute difference in temperatures between the insides and outsides of both homes differed by less than $2 \%$.

\subsubsection{Wall Moisture Risk}

Lower sheathing temperatures increase the risk of condensation on the interior side of the sheathing. Grin and Lstiburek (2012) explored the condensation potential in several hybrid (cavity and exterior insulation) wall assemblies in Minneapolis and New Orleans using hygrothermal modeling with WUFI software. On an hourly basis, the wall insulated with $1.5 \mathrm{in}$. of exterior extruded polystyrene had a $47 \%$ reduction in condensation potential over the standard wall assembly in Minneapolis. The exterior insulated wall assembly in New Orleans (CZ 2) did 
not exhibit a significant reduction in condensation potential due to the warmer winter temperatures.

Field data in Savannah were analyzed for each minute to quantify the time either home had a risk of condensation. Figure 41 and Figure 42 show the dew point of the air in the living space and the interior surface temperatures of the sheathing for the NNE walls in the Zip and ZipR homes. The yellow line indicates when the sheathing temperature is lower than the interior air dew point, which indicates a risk for condesation. The ZipR home's NNE wall had 83\% less time at risk for condensation than the Zip home. During an average winter day, the Zip home's NNE wall was at risk for condensation for 185 minutes. During the same time frame, the ZipR home's NNE wall was at risk for condensation for 12 minutes.

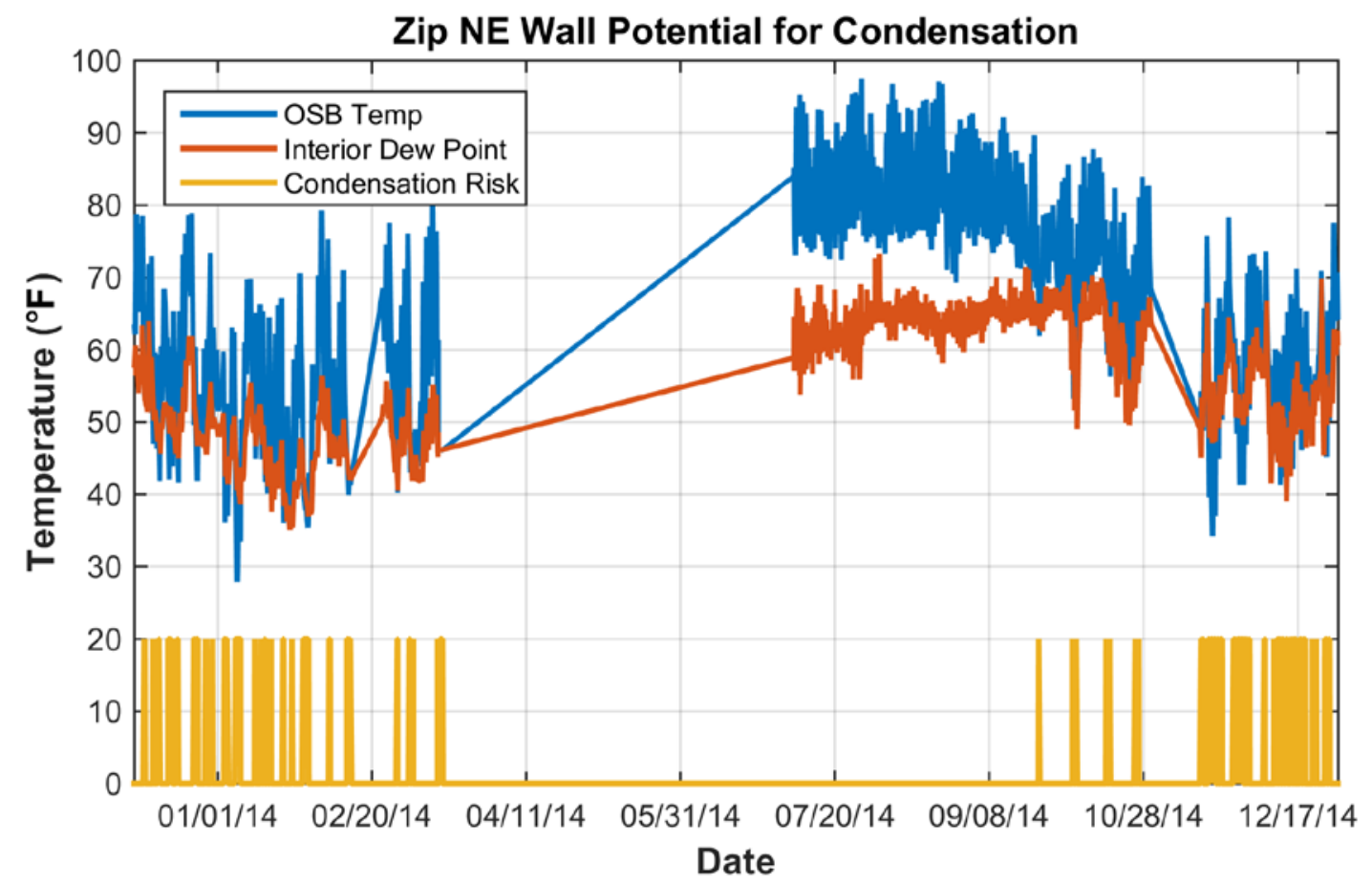

Figure 41. Periods of potential condensation for Zip house on northeast wall. A yellow line at 20 indicates a risk of condensation. 


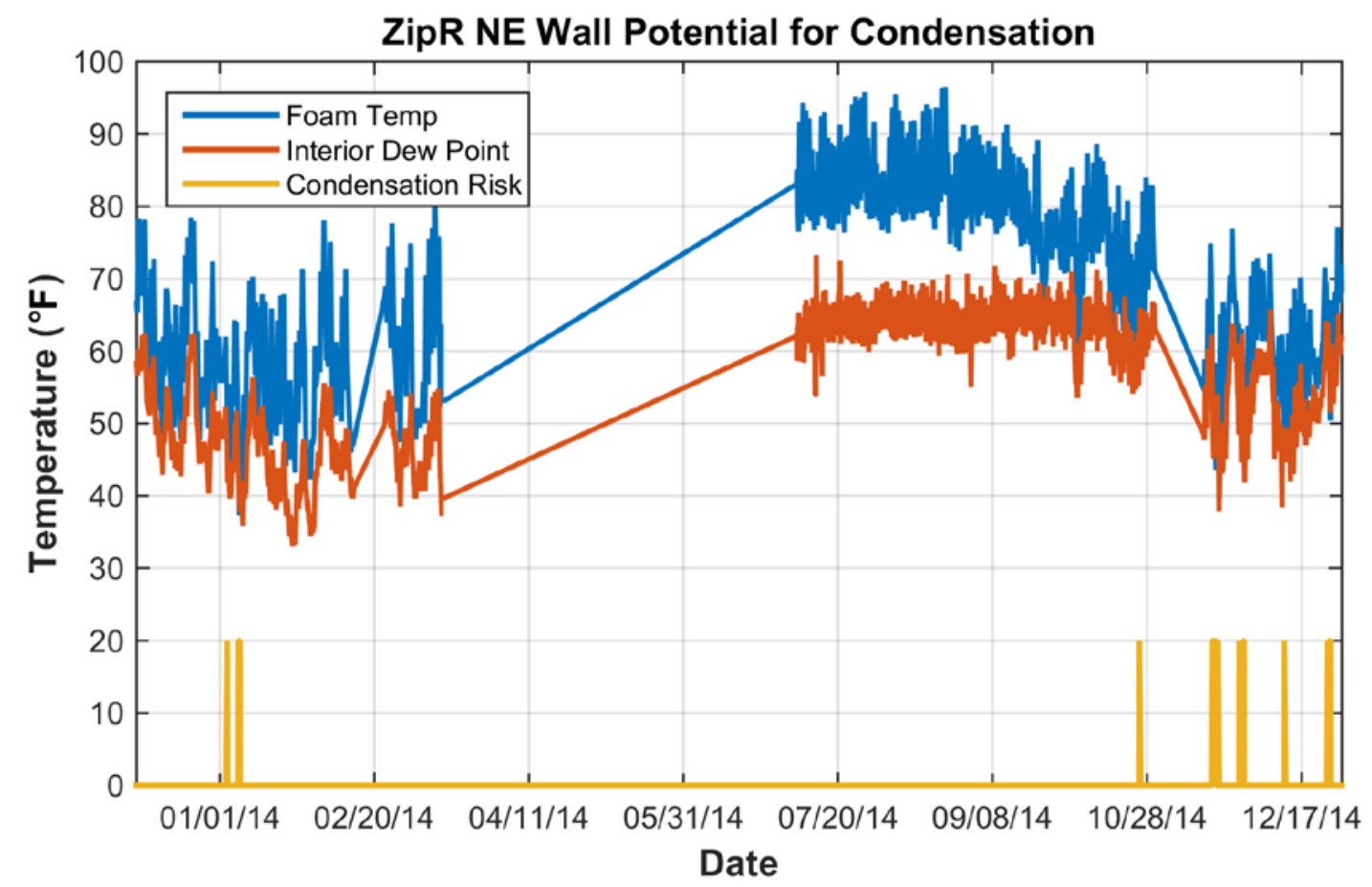

Figure 42. Periods of potential condensation for ZipR house on northeast wall. A yellow line at 20 indicates a risk of condensation.

Condensation potential calculated at all sensor locations is detailed in Table 16. Time of condensation risk was reduced in the ZipR home for all sensor locations by $19 \%$ to $96 \%$. The NNE2 walls, the front left corners of both homes, had the least impact due to complete shading from the porches.

Table 16. Hours of Condensation Risk for All Sensor Locations during 300 Days of Monitoring

\begin{tabular}{c|c|c|c}
\hline $\begin{array}{c}\text { Sensor } \\
\text { Location }\end{array}$ & $\begin{array}{c}\text { Zip Hours of } \\
\text { Condensation } \\
\text { Potential }\end{array}$ & $\begin{array}{c}\text { ZipR Hours of } \\
\text { Condensation } \\
\text { Potential }\end{array}$ & $\begin{array}{c}\text { Percent Reduction } \\
\text { in Condensation } \\
\text { Potential }\end{array}$ \\
\hline NNE & 636 & 41 & $94 \%$ \\
\hline NNE2 & 474 & 383 & $19 \%$ \\
ESE & 932 & 263 & $72 \%$ \\
ESE2 & 1,127 & 78 & $93 \%$ \\
SSW & 820 & 119 & $85 \%$ \\
\hline WNW & 760 & 33 & $96 \%$ \\
\hline
\end{tabular}

The longer the wall is continuously at risk for condensation, the higher the potential for mold growth and durability issues. The duration the NE walls were susceptible to condensation was explored in Table 17. Figure 43 shows the number of occurrences the NE wall was at risk for condensation and the duration of each event. The traditional Zip wall had far more risk events and a much longer average duration. 
Table 17. Duration of Condensation Risk Events at Sheathing in NE Walls

\begin{tabular}{c|c|c}
\hline & $\begin{array}{c}\text { Zip Condensation } \\
\text { Risk Event }\end{array}$ & $\begin{array}{c}\text { ZipR Condensation } \\
\text { Risk Event }\end{array}$ \\
\hline \# of Events & 153 & 43 \\
Minimum (min) & 1 & 1 \\
Mean (min) & 250 & 57 \\
Maximum (min) & 2,451 & 823 \\
Standard Deviation (min) & 410 & 147 \\
\hline
\end{tabular}

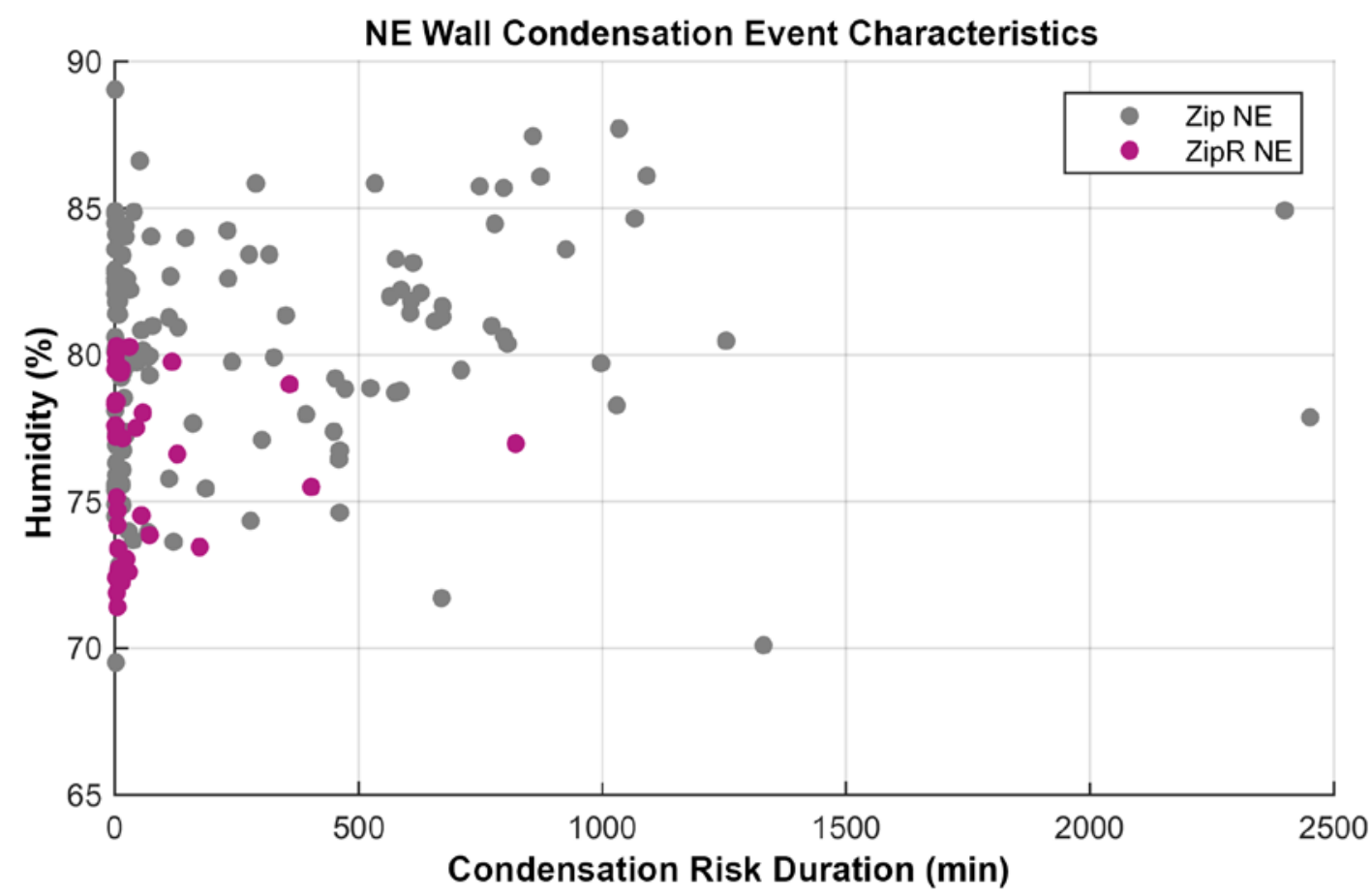

Figure 43. Plot showing the duration a wall cavity was exposed to high humidity levels when the temperature at the sheathing was lower than the dew point

\subsubsection{ASHRAE 160}

ASHRAE Standard 160-2009: Criteria for Moisture-Control Design Analysis in Buildings specifies conditions for minimizing mold growth, stating that "in order to minimize problems associated with mold growth on the surfaces of components of building envelope assemblies, the following condition shall be met: a 30-day running average surface relative humidity $<80 \%$ when the 30 -day running average surface temperature is between $5^{\circ} \mathrm{C}\left(41^{\circ} \mathrm{F}\right)$ and $40^{\circ} \mathrm{C}\left(104^{\circ} \mathrm{F}\right)$ " (ASHRAE 2009).

The 30-day temperature and humidity running averages were computed for the Zip and ZipR NNE wall, as shown in Figure 44 and Figure 45. The 30-day running average NNE wall temperatures for both homes fell between $41^{\circ} \mathrm{F}$ and $104^{\circ} \mathrm{F}$. In the winter of 2014 , both homes' NNE walls maintained 30-day running average humidities lower than $80 \%$. During the winter the following year, both homes' humidities increased; however, only the Zip home's 30-day running average humidity exceeded 80\%, causing it to fail the ASHRAE Standard 160-2009. 


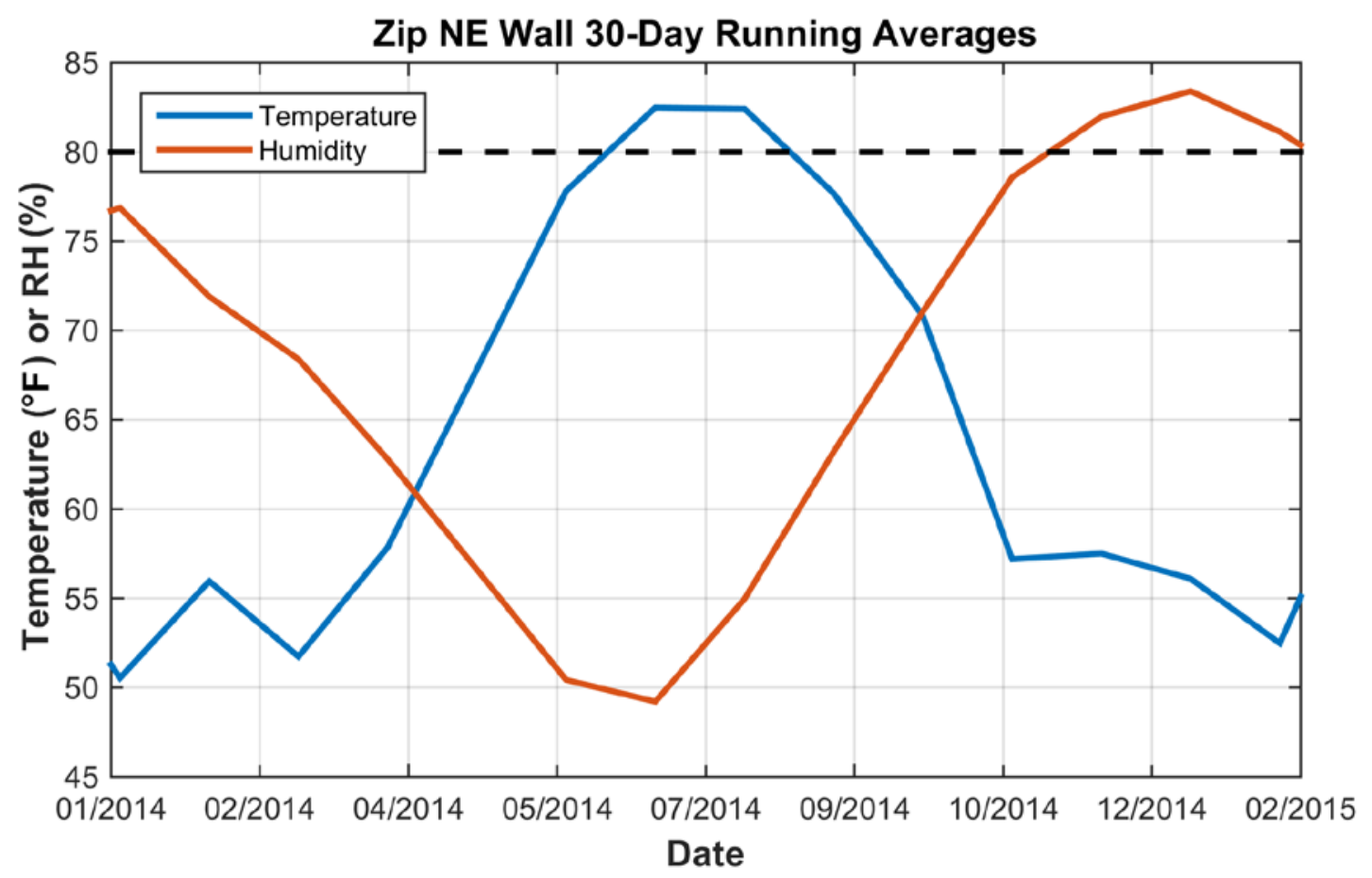

Figure 44. Zip NE wall 30-day temperature and humidity running averages

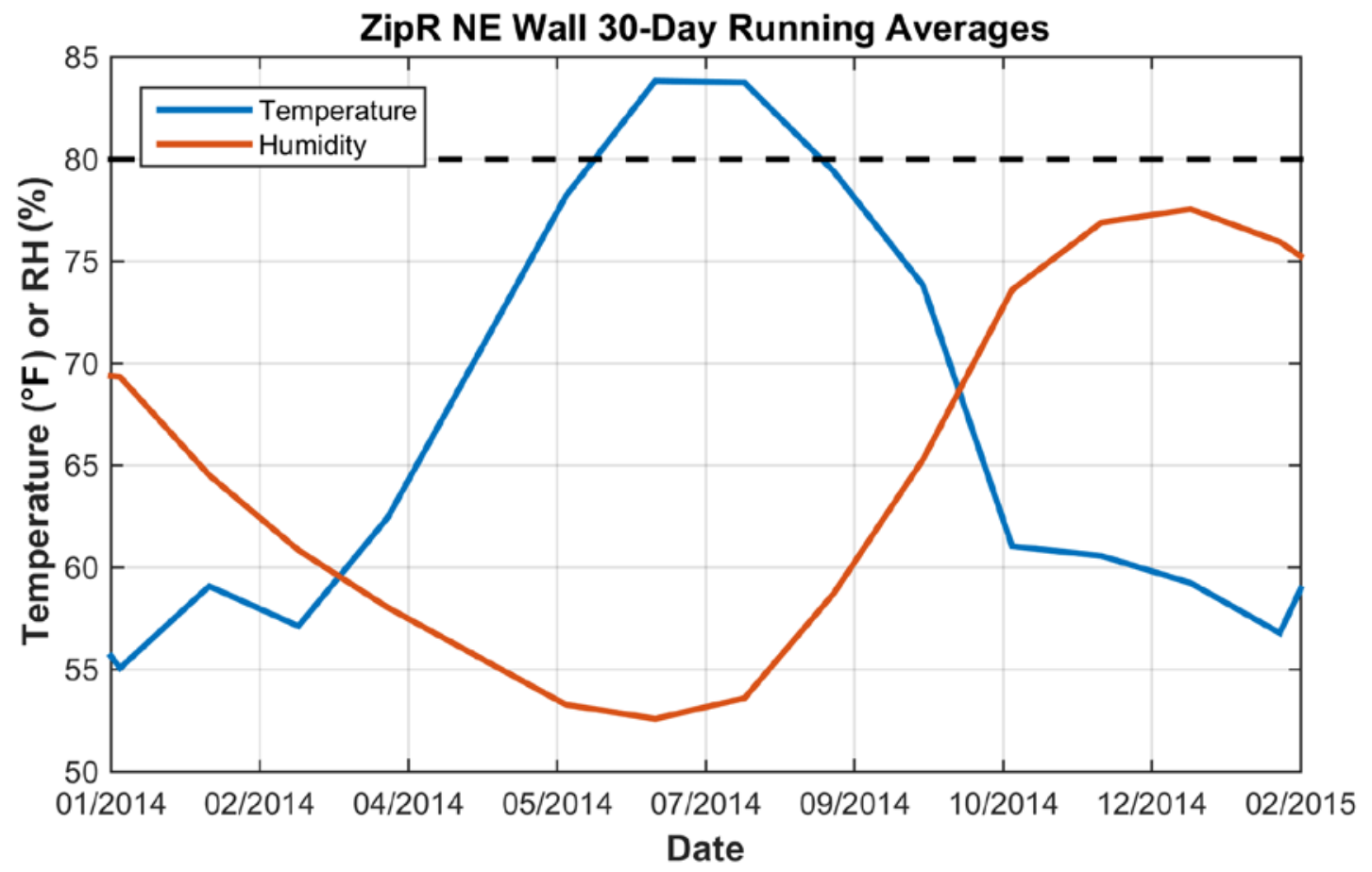

Figure 45. Zip NE wall 30-day temperature and humidity running averages 
Ueno studied wall moisture conditions in double-stud walls and evaluated their performance under ASHRAE 160 guidelines and an Isopleth Analysis based off of Viitanen and Ojanen's modeled nature of mold growth (Ueno 2015; Viitanen and Ojanen 2005). Ueno plotted the humidity and temperature of a north-facing wall and overlaid the isopleth curve detailing conditions optimal for mold growth. The same process was applied to the Zip and ZipR NNEfacing walls. Average hourly temperature and humidity are shown in Figure 46 and Figure 47. The ZipR wall had far fewer hours in conditions susceptible to mold growth than the Zip wall.

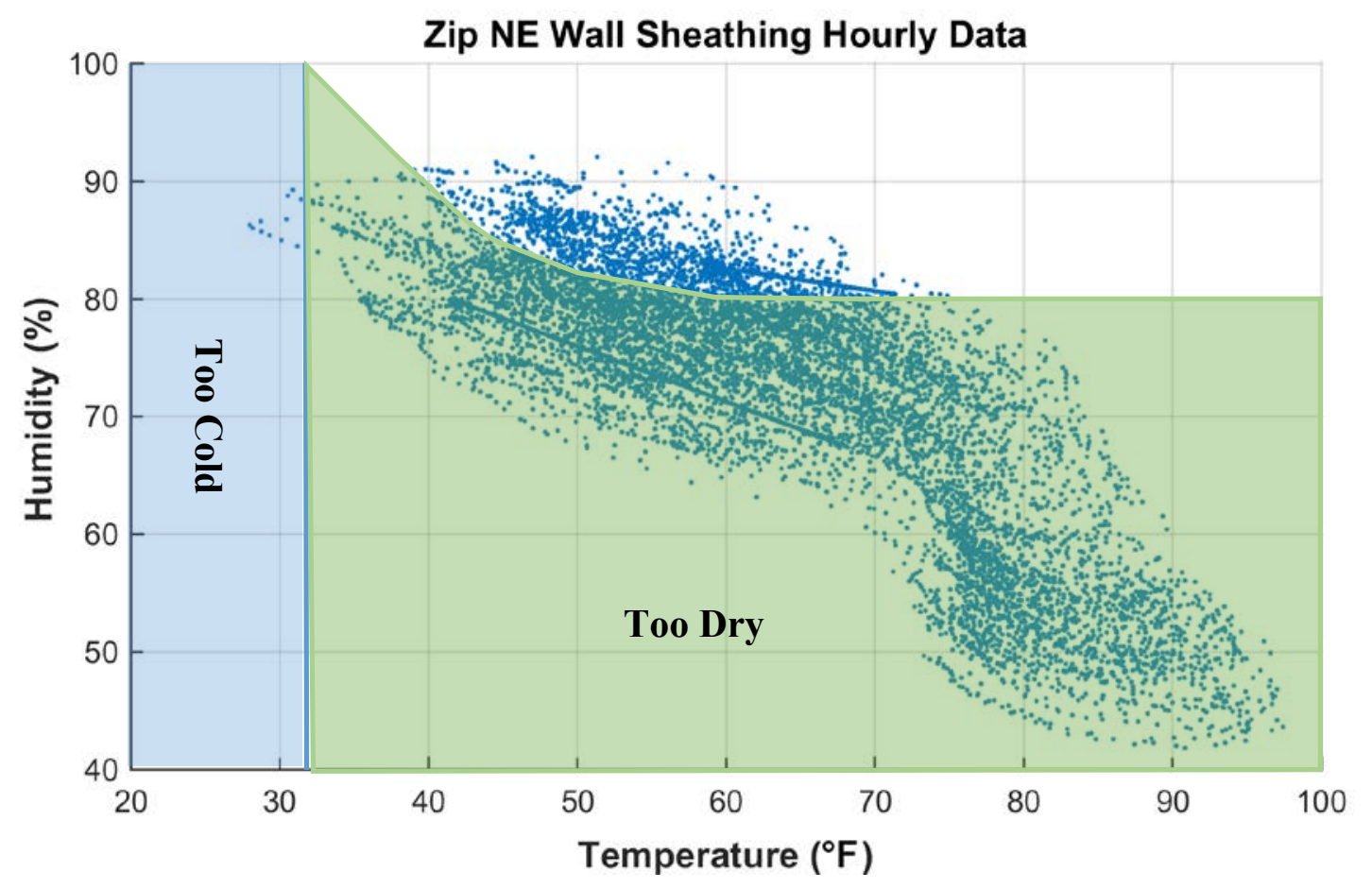

Figure 46. Zip NNE sheathing hourly temperature and humidity 


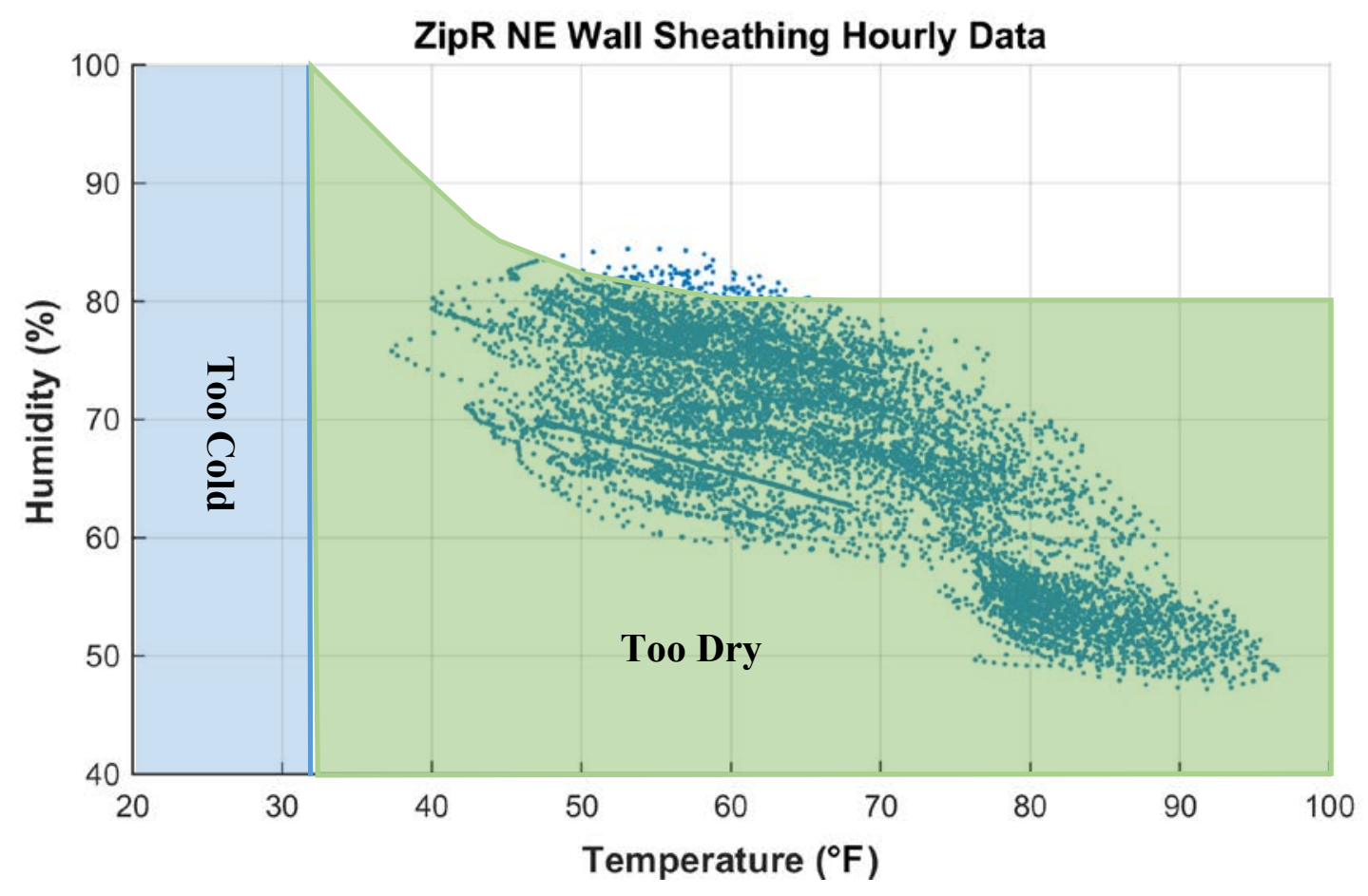

Figure 47. ZipR NNE sheathing hourly temperature and humidity 


\section{Resident Experience}

\subsection{LaFayette Resident Survey}

Resident surveys were created and analyzed by Southface and delivered and collected by LHA. The survey was designed to determine occupants' perceptions of comfort and satisfaction with the various energy-efficiency measures incorporated into their homes. Surveys did ask which unit configuration the respondent lived in but were otherwise anonymous. Surveys were returned for all 30 duplex units.

\subsubsection{Resident Energy Conservation Behavior}

The survey asked questions to assess the residents' behaviors that had an impact on energy use of the DHW and heating and air-conditioning systems. Results of self-assessments of water use and set points for all 30 homes are shown in Figure 48 and Figure 49.

For hot water use, most respondents reported using cold water to wash clothes (21); successively fewer respondents used warm (eight) and hot water (five). Reported typical shower durations were 6-10 minutes for the majority of households (17); a significant number (12) took 11-20 minute showers.

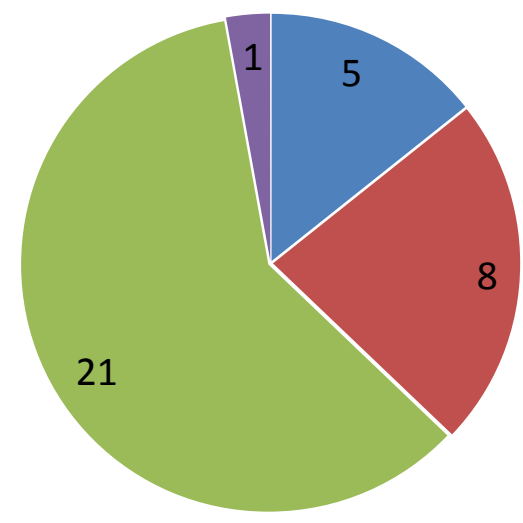

Hot $\square$ Warm $\square$ Cold $\square$ Not applicable

Figure 48. At what temperature water do you wash your clothes? (Please check all that apply.)

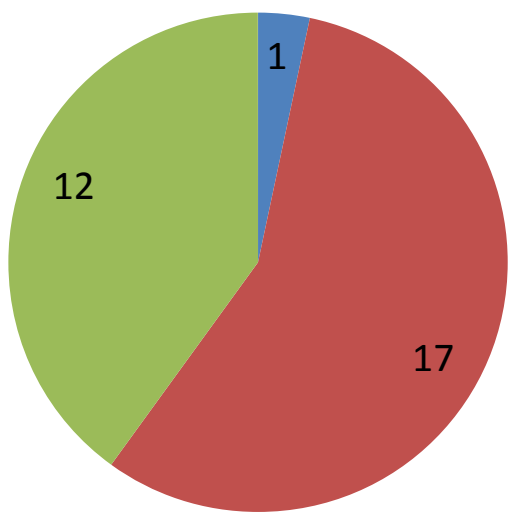

5 or less $\square$ 6-10 $\square 11-20$

Figure 49. What is the typical duration of a shower in your household (minutes)?

The most common HVAC thermostat set point range during both heating (20 of 30) and cooling (15 of 30) seasons was $69^{\circ}-72^{\circ} \mathrm{F}$ (Figure 50 and Figure 51). During the winter, nine residents used a set point of $68^{\circ} \mathrm{F}$ and lower; seven did during the summer. The residents clearly had a preference for maintaining their homes at cooler temperatures year round, which led to energy saving in the winter and higher energy use during the summer. 


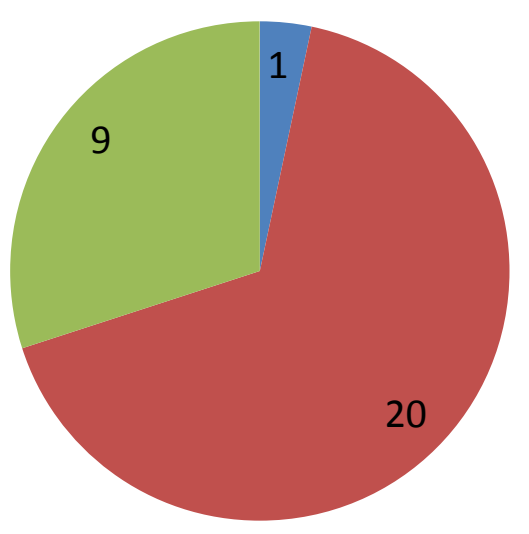

68 and below $\quad$ 69-72 $\quad$ 73-75

Figure 50. In general, what temperature (in degrees) is your thermostat set to during the winter?

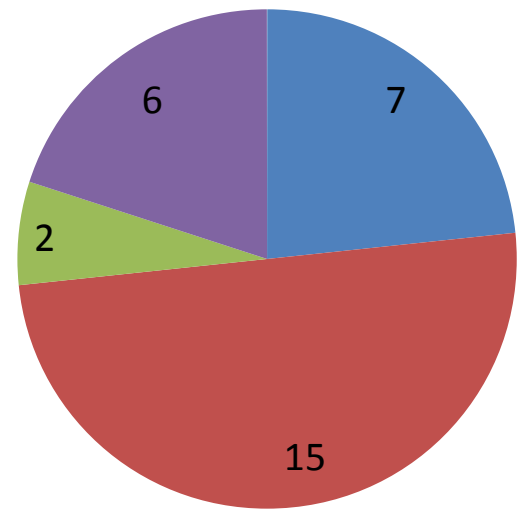

68 and below $\square 69-72 \square 73-75 \square$ NA

Figure 51. In general, what temperature (in degrees) is your thermostat set to during the summer?

Most residents did not use the setback capabilities of their programmable thermostats (16 of 30) or did not know if they had (3 of 30) (Figure 52).

Additional resident education might help residents lower their energy consumption and utility costs without significantly sacrificing comfort. Survey results can help identify high-impact areas. For instance, taking advantage of the setback capabilities of the programmable thermostats would likely result in significant savings, especially for residents with cooling set points at $72^{\circ} \mathrm{F}$ or lower. Similarly, encouraging shorter showers would lead to reductions in water heating energy and water and sewer use. Figure 53 shows that although $63 \%$ of the respondents rate their electricity bill costs as Low or Fair, a significant number are unsure or rate them as High (11 of 30 ), and would likely be receptive to trusted and targeted messaging. 


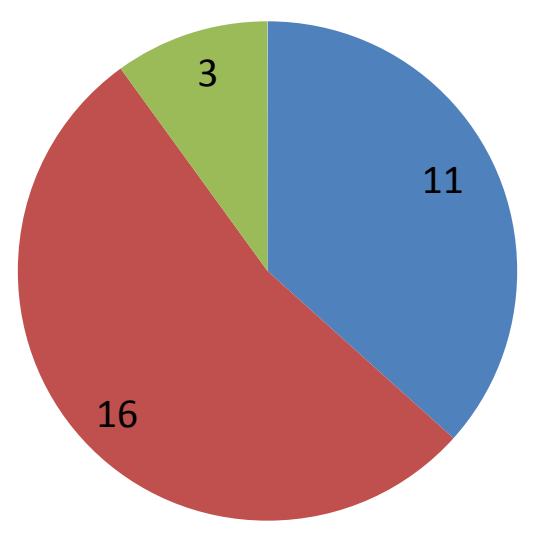

Yes No I don't know how

Figure 52. Have you utilized your thermostat's ability to automatically adjust temperature settings throughout the day?

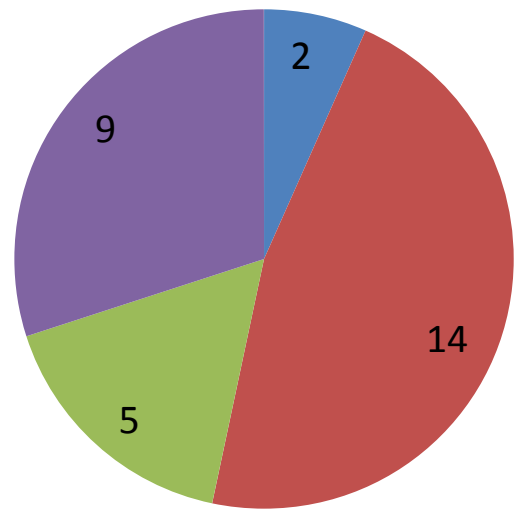

High $\square$ Fair $\square$ Low $\square$ Unsure

Figure 53. How would you rate the cost of your electric bills?

\subsubsection{Domestic Hot Water Supply Satisfaction}

The HPWHs were set in Efficiency (heat pump-only) mode to function most energy efficiently. Water heater temperature was set at $120^{\circ} \mathrm{F}$. The residents do not have access to the water heater controls to change either mode or temperature. Restricting resident access to mechanical systems is typical in rental apartments, and LHA is invested in helping residents minimize their utility bills. A resident survey attempted to assess whether these settings provided hot water at a sufficient rate to meet the expectations and needs.

More than $50 \%$ of respondents indicated that they planned their shower timing to avoid running out of water (Figure 54). However, more than $70 \%$ either never or seldom experienced a shortage of hot water while showering or bathing (Figure 55). These data do not show whether the respondents' behavior in timing showers was due to experiences in the LaFayette homes or was learned behavior from past experiences, especially because they had lived in these homes for less than one year. 


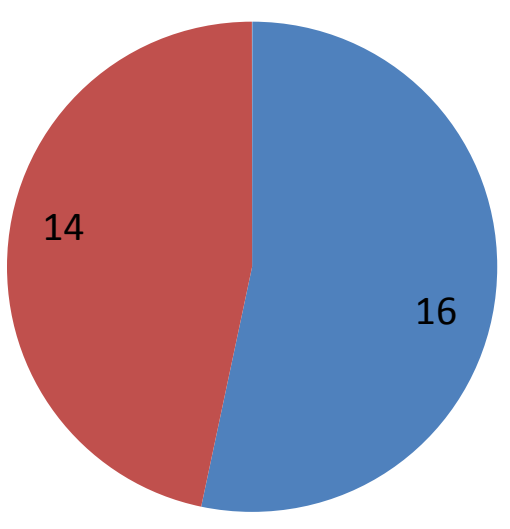

Yes No

Figure 54. Do you avoid taking consecutive showers to prevent running out of hot water?

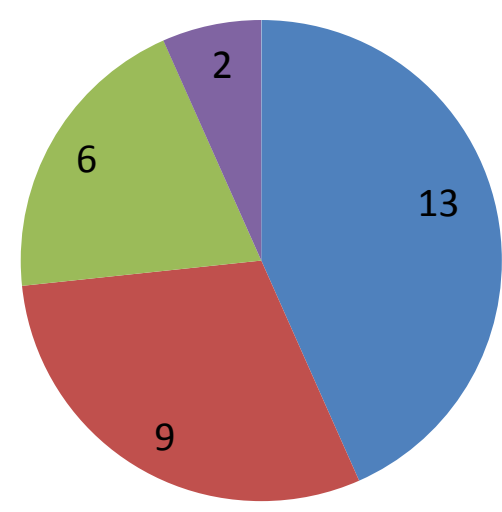

Never $\square$ Seldom $\square$ Sometimes $\square$ Often

Figure 55. How often, if ever, do you experience shortage of hot water while showering/bathing?

Reported hot water shortages while using the kitchen sink were very rare, $10 \%$ answering Sometimes or Often (Figure 56).

Overall satisfaction with hot water supply was very high; more than $93 \%$ of residents agreed or strongly agreed that they were satisfied (Figure 57). The HPWH in energy-efficient mode appeared to be capable of meeting the hot water demands of families in the two-bedroom and three-bedroom duplex apartments. LHA had not received any resident complaints or requests with respect to hot water demand. 


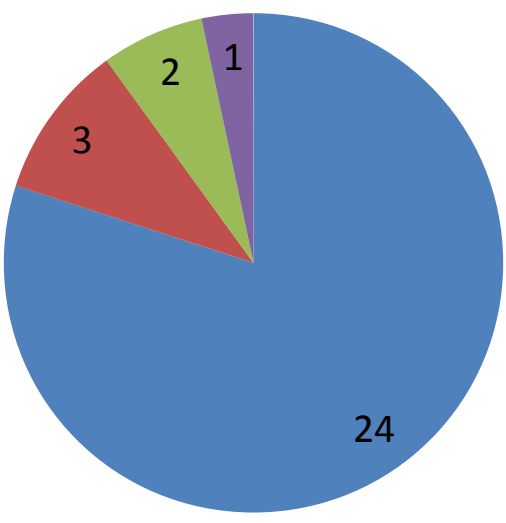

Never $\backsim$ Seldom $\backsim$ Sometimes $\square$ Often

Figure 56. How often, if ever, do you experience a shortage of hot water while using the kitchen sink?

\subsubsection{Heat Pump Water Heater Noise}

Previous research has identified HPWH operation noise as a barrier to acceptance of installation inside of living space, such as in the utility closets in the LaFayette community (Chasar and Martin 2013). This was one factor that led the research team to recommend a solid door on the utility closet and ducting of the HPWH to and from the encapsulated attic. Both the HPWH and the HVAC air handling unit were placed inside each closet. The resident survey asked several questions to help identify whether this particular installation, which runs $100 \%$ in heat pump mode, had any negative impact associated with noise (Figure 58 through Figure 60). 


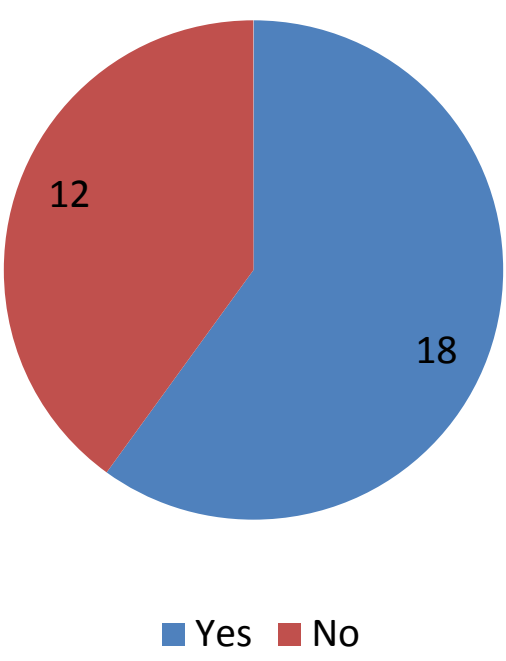

Figure 58. Do you hear noise from the mechanical equipment behind the locked doors in your home?

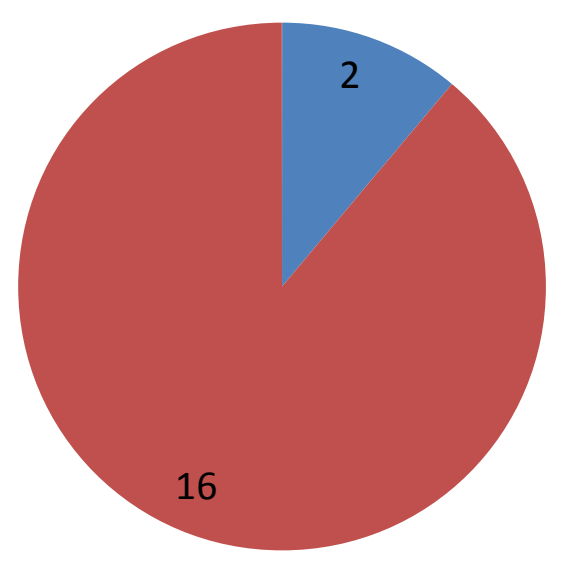

$\square$ Yes $\square$ No

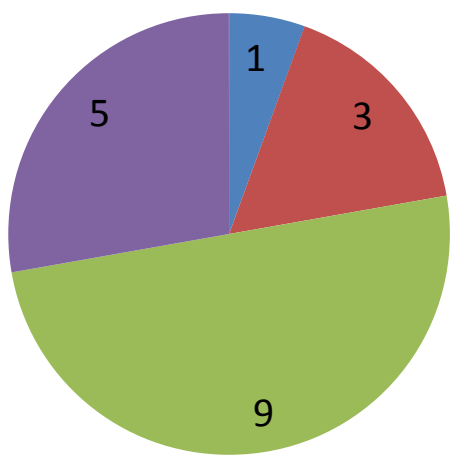

Always Often

Sometimes $\square$ Seldom

Figure 59. How often do you hear the operation of mechanical equipment behind the locked doors in your home?

Figure 60. Does the noise disturb your daily activities? If yes, please explain.

Examination of more detailed questions allowed the researchers to identify that, of the 18 residents who indicated that they heard noise from the utility closet, 11 were related to the HPWH, four to the air handling unit, and three could have been either. Even though 18 residents reported hearing noise, only two indicated that it disturbed their daily activities. LHA has reported it has not received complaints from residents and does not plan to make changes to HPWH operation based on noise. 


\subsubsection{Resident Comfort}

The survey also asked questions to assess the residents' perception of comfort. Results of selfassessments for all 30 homes are shown in the charts below.

All respondents reported that they were comfortable in their homes during every season and that they were satisfied with the overall level of comfort (Figure 61 and Figure 62). All but three respondents reported that all rooms in their homes were equally comfortable (Figure 63). Only two respondents reported issues with indoor air quality. The survey did not ask if the residents had known allergies or had had previous indoor air quality-related issues. Figure 64 shows that only two respondents experienced issues with indoor air quality polutants such as pollen, allergens, and other odors.

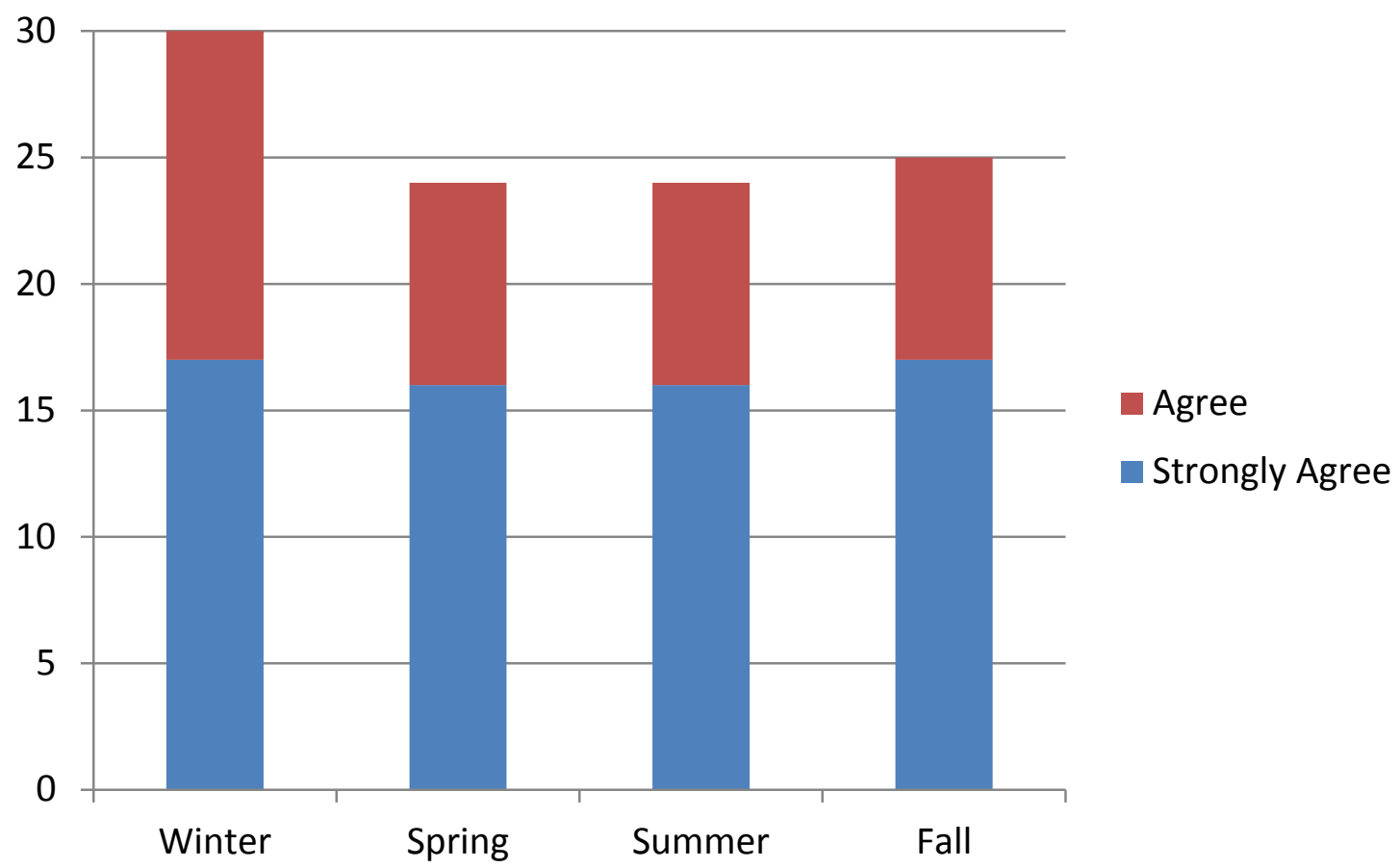

Figure 61. My home feels comfortable during every season: (winter, spring, summer, and fall). 


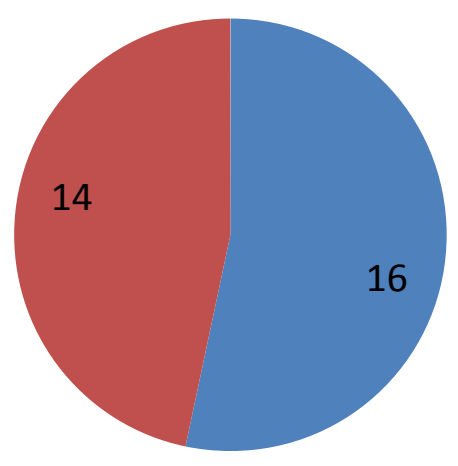

$\begin{array}{ll}\square \text { Strongly agree } & \text { Agree } \\ \square \text { Disagree } & \text { Strongly disagree }\end{array}$

Figure 62. I am satisfied with the overall comfort of my home.

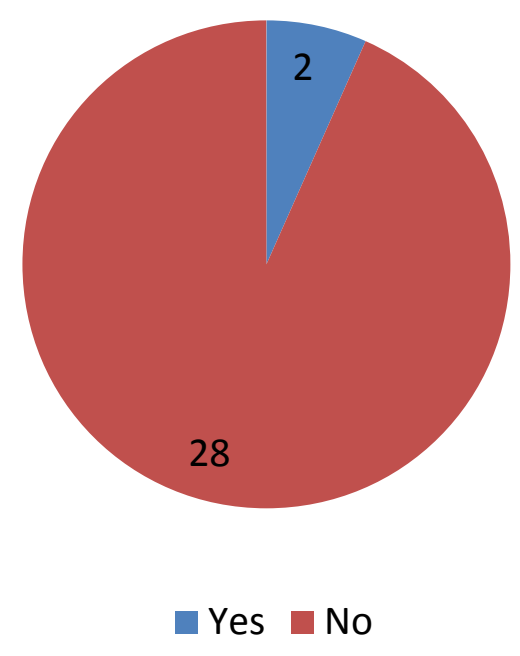

Figure 64. Do you experience issues with the indoor air quality (pollen, allergens, odors, etc.)?

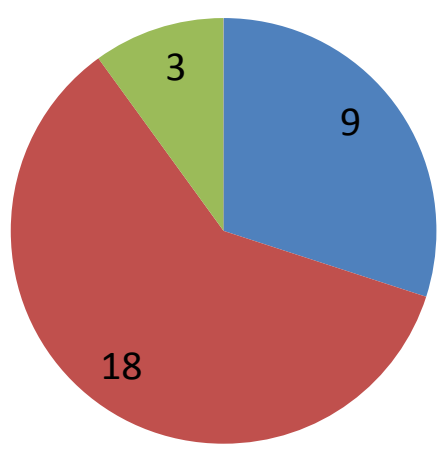

$\begin{array}{ll}\square \text { Strongly agree } & \text { Agree } \\ \square \text { Disagree } & \text { Strongly disagree }\end{array}$

Figure 63. All rooms in my home are equally comfortable. 


\section{Successes and Failures}

\subsection{Savannah Gardens}

The BEopt models indicated that slab edge insulation would have resulted in a net annual increase in energy consumption, because it would have decreased heating loads and increased cooling loads. However, when the house was analyzed using REM/Rate software, R-5 slab insulation would have decreased heating loads but not impacted cooling loads, conforming to the EPAct required reductions to qualify for a $\$ 2,000$ tax credit. Additional field research is necessary, particularly on raised slab foundations that are common in the Southeast, to collect data to refine modeling software algorithms and improve consistency across all modeling software platforms.

Although the addition of the ZipR sheathing compared to the Zip was not predicted to result in significant annual energy savings $(1.5 \%)$, measurements revealed significant differences in wall performance, even in the temperate climate of Savannah. Walls with ZipR insulated sheathing experienced smaller swings in temperature, less extreme winter and summer peaks, and lower risks of condensation. Preliminary HVAC energy consumption data indicate a decrease in total runtime and total energy consumption. Additional research is necessary to verify this linkage.

\subsection{JMC Patrick Square}

A builder that participates in an energy-efficiency or green building program may seem to be an ideal candidate for upgrading its product to a zero energy ready home; however, success lies in the execution of multiple details throughout the construction process. ENERGY STAR, WaterSense, Indoor airPlus and the Zero Energy Ready Home program have created a comprehensive package of checklists and other project evaluation tools, but these tools cannot replace daily quality assurance and proactive communication to and between trades to ensure that changes to standard building practice are being integrated efficiently and successfully. If one relies on the building program checklists to catch errors, it is often too late, or prohibitively expensive, to correct the errors. The failure to properly install slab edge insulation is a great example of a costly error that was identified too late to fix, and disconnect between decision makers and those that must execute on the decisions.

The builder did make many improvements in the New Construction Test House relative to the base specifications:

- Sealed attic with R-20 ocSPF

- Air leakage reduced $64 \%$ compared to average (to $2.5 \mathrm{ACH}_{50}$ )

- Ducts in conditioned space

- Duct leakage to outside reduced $100 \%$ (to 0 )

- Window package improved to meet ENERGY STAR v.3

- Seasonal energy efficiency ratio 16 air conditioner

- $0.82 \mathrm{EF}$ gas tankless water heater. 
The cumulative impact predicted by BEopt for all these changes is a modest $3 \%$ savings in total source energy over the base model. The primary driver of this surprisingly low savings improvement is the fact that the base home has R-38 attic insulation, and the New Construction Test House has R-20 roofline insulation. This decrease in total enclosure UA counteracts the impacts of the upgrade measures.

Market-ready solutions for high-R roofline assemblies creating sealed attics that will be acceptable to production builders are necessary to reach increased levels of energy savings.

\subsection{LaFayette}

The kick-off meeting with the subcontractors and A.O. Smith and the subsequent visit from Johns Manville representatives were instrumental in reducing errors during construction. The meeting also helped the framers understand advanced framing, the HVAC contractor establish when and where to install the duct for the HPWH, and the masonry crew to sequence the installation of the slab edge insulation. The product manufacturer representatives provided advice and tools to successfully install their products. Good communication throughout the entire construction process helped find solutions to issues installing the insulation.

The duplex units were completed in early 2014 but remained unoccupied for a few months until LHA could relocate qualified tenants into the units. During this downtime, LHA was responsible for the utility bills and noticed that the unoccupied units had electricity bills near $\$ 70 / \mathrm{month}$. The cause was the ventilation air cycler operating the central fan integrated ventilation system (fresh air ducted to the return plenum of the air handling unit) for 30 minutes of every hour. The air handling unit fan consumed a lot of energy and brought in unconditioned air, which likely caused the high monthly bills. Other contributing factors to the consumption during the unoccupied times were the refrigerator and standby water heater losses. The monthly bills alarmed LHA, which then set the thermostat to temperatures to keep pipes from freezing and reprogrammed the air cycler to never operate. It is unknown if the air cycler was ever reprogrammed when the units became occupied. Communication and education of the facility staff or installation of a lower energy ventilation system might have prevented this problem. 


\section{Conclusions}

- What is the average daily HPWH COP as a function of daily hot water use and real-world variations in use patterns?

HPWH COP values are dependent on several variables including intake air temperature and humidity, inlet water temperature, number of heat pump operation events, total hot water demand, hot water demand during a heat pump operation event, and tank set point temperature (Sweet, Francisco, and Roberts 2015). Because of this complexity, strong correlations between COP and any single variable were not necessarily established. The values calculated in this study are similar to other field-monitoring studies and laboratory studies of unducted HPWHs.

- How well does the HPWH keep up with hot water demand, and do occupants change the operating mode or temperature set point to ensure they have enough hot water?

The HPWH satisfied occupant hot water demand in the efficiency operating mode. No complaints were reported to LHA or from the homeowner in Savannah. A survey was administered to the residents in 30 duplex units in LaFayette, and $93 \%$ of the tenants agreed that they had satisfactory hot water supply. However, the homeowner in Savannah increased their tank set point temperature to $150^{\circ} \mathrm{F}$ from $120^{\circ} \mathrm{F}$. This was not necessarily due to unsatisfactory supply from the HPWH in efficiency mode, because it was turned off for a long period before they increased the set point. The increased set point reduced the COP from 3.1 to 2 and the total hot water consumption by $21.1 \mathrm{gal} / \mathrm{day}$.

- What effect does HPWH exhaust air have on temperature and relative humidity conditions in the attic space, and is there an effect on HVAC system performance that is also in the encapsulated attic?

The air conditioning provided by the HPWH affects the temperature of the mechanical closet and attic space only during the time the heat pump is operating. Shortly after the heat pump stops operating, the values return to previous levels. Encapsulated attic peak humidity levels can be reduced if the heat pump operates during the first half of the day compared to when it operates later in the day or compared to an alternative DHW system.

- What is the impact of different ducting configurations on HPWH COP?

Different ducting strategies had no impact on COP. The intake air temperature increased slightly but not enough to increase COP.

- How much does the insulated sheathing affect the cavity temperature of the exterior walls?

The average ZipR WNW wall sheathing was $6.4^{\circ} \mathrm{F}$ warmer in the winter and $3.4^{\circ} \mathrm{F}$ cooler in the summer than the Zip WNW wall sheathing. The ZipR wall also experienced less severe daily temperature fluctuations, as exhibited by its lower daily temperature swing.

- What is the performance difference of both wall systems under extreme weather conditions and the impact on their resilience? 
The 30-day running average NNE wall temperatures for both homes fell between $41^{\circ} \mathrm{F}$ and $104^{\circ} \mathrm{F}$. In the winter of 2014 , both homes' NNE walls maintained 30-day running average humidities lower than $80 \%$. During the winter the following year, the humidity in both homes increased; however, only the Zip home's 30-day running average humidity rose above $80 \%$, causing it to fail the ASHRAE Standard 160-2009. The ZipR wall had far fewer hours in conditions susceptible to mold growth than the Zip wall.

- How well does the HPWH keep up with hot water demand, and do occupants report challenges in meeting hot water demand? How well did residents accept this emerging HPWH technology as installed?

More than $50 \%$ of all survey respondents indicated that they plan their shower timing to avoid running out of water (Figure 54). However, more than $70 \%$ indicated that they either Never or Seldom have experienced a shortage of hot water while showering or bathing. Reported hot water shortages while using the kitchen sink were very rare; $10 \%$ answered Sometimes or Often (Figure 56). Overall satisfaction with hot water supply was very high; more than 93\% of residents Agreed or Strongly Agreed that they were satisfied. The HPWH in energy-efficient mode appears capable of meeting the hot water demands of families in the two-bedroom and three-bedroom duplex apartments. LHA has not received any resident complaints or requests with respect to hot water demand.

Despite the fact that 18 residents reported hearing noise, only 2 indicated that it disturbed their daily activities.

- What was the self-reported resident comfort and interaction with the energy conservation measures?

All respondents reported that they were comfortable in their homes during every season and that they were satisfied with the overall level of comfort. All but three respondents reported that all rooms in their homes were equally comfortable. Only two respondents reported issues with indoor air quality. The survey did not ask if the residents had known allergies or had had previous issues related to indoor air quality.

- What are the gaps between the green builder's standard package and DOE Challenge Home/Zero Energy Ready Home program specifications?

JMC's standard home design included air handling units and ducts in a vented attic with R-38 insulation. ENERGY STAR Version 3 requires all HVAC equipment to be placed in conditioned space, so the builder determined that the most feasible solution was to seal the roofline by installing 5.5-6 in. (R-20) of ocSPF. The concomitant increase in total Uvalue times insulated surface area resulted in a predicted net increase in annual energy consumption of $4 \mathrm{MBtu}$. The builder improved the total envelope UA value by upgrading the windows and adding R-5 slab insulation, albeit the slab insulation was installed ineffectively. Furthermore, multiple deficiencies were discovered during final inspection using Zero Energy Ready Home building certification checklists, but remedies were either too late or too costly. 


\section{References}

A.O. Smith. 2011. Service Handbook-Residential Hybrid Electric Heat Pump Water Heater for Models: PHPT-60 and PHPT-80. Ashland City, TN.

A.O. Smith. 2012. Hybrid Electric Heat Pump Water Heater Installation Instructions and Use \& Care Guide. Ashland City, TN.

A.O. Smith. 2014. VOLTEX ${ }^{\circledR}$ Hybrid Electric Heat Pump 50-Gal Water Heater. Ashland City, TN.

Amarnath, A., and J. Bush. 2012. "Heat Pump Water Heaters: Field Evaluation of New

Residential Products.' ACEEE Summer Study on Energy Efficiency in

Buildings. www.aceee.org/files/proceedings/2012/data/papers/0193-000013.pdf.

ASHRAE. 2009. ASHRAE Standard 160-2009: Criteria for Moisture-Control Design Analysis in Buildings. Atlanta, GA: ASHRAE.

Boudreaux, P., S. Pallin, and R. Jackson. 2014. Moisture Performance of Sealed Attics in the Mixed-Humid Climate. Oak Ridge, TN: Oak Ridge National Laboratory.

Chasar, D., and E. Martin. 2013. Efficient Multifamily Homes in a Hot-Humid Climate by Atlantic Housing Partners (Subcontract Report). Golden, CO: National Renewable Energy Laboratory.

Community Housing Services Agency Inc. 2012. Savannah Gardens. Retrieved from http://chsadevelopment.org/.

Ecotope Inc, and Northwest Energy Efficiency Alliance. 2015. Heat Pump Water Heater Model Validation Study. Seattle, WA.

Fairey, P., J. Tait, D. Goldstein, D. Tracey, M. Holtz, and R. Judkoff, R. n.d.. The HERS Rating Method and the Derivation of the Normalized Modified Loads Method. Retrieved September 16, 2015: www.fsec.ucf.edu/en/publications/html/FSEC-RR-54-00/.

Grin, A., and J. Lstiburek. 2012. Moisture and Structural Analysis for High Performance Hybrid Wall Assemblies (Subcontract Report). Golden, CO: National Renewable Energy Laboratory.

Johns Manville. 2014. "JM Spider Plus Blow-in Custom Fiber Glass Insulation and Delivery System.” www.jm.com/content/dam/jm/global/en/building-insulation/Files/BI Data Sheets/Resi and Commercial/BID-0209 JM Spider Plus Data Sheet.pdf.

Larson, B., K. Bedney. 2011. Interim Report and Preliminary Assessment of AO Smith Voltex PHPT-80 Hybrid Heat Pump Water Heater. Bonneville Power Administration.

Rinnai. 2015. Rinnai V65i. Retrieved September 21, 2015: www.rinnai.us/waterheater/product/v65i-reu-vc2025ffu-us\#tabs-2. 
Shapiro, C., and S. Puttagunta. (2013). Field Performance of Heat Pump Water Heaters in the Northeast. www.carb-swa.com/Collateral/Documents/CARB-SWA/Research/58115_sw 201308-07.pdf.

Sparn, B., L. Earle,D. Christensen, J. Maguire, E. Wilson, E., and C.E. Hancock. 2013. Field Monitoring Protocol: Heat Pump Water Heaters (Technical Report, NREL/TP-5500-57698).

Golden, CO: National Renewable Energy Laboratory.

Sweet, M.L., A. Francisco, and S.G. Roberts. 2015. Heat Pump Water Heater Ducting Strategies with Encapsulated Attics in Climates Zones 2 and 4.

DOE. 2015. "Insulation Materials.” Accessed September 21, 2015:

http://energy.gov/energysaver/articles/insulation-materials.

Ueno, K. 2015. Monitoring of Double-Stud Wall Moisture Conditions in the Northeast (Subcontract Report, NREL/SR-5500-63393). Golden, CO: National Renewable Energy Laboratory: www.nrel.gov/docs/fy15osti/63393.pdf?gathStatIcon=true.

Viitanen, H. J. Vinha, R. Peuhkuri, T. Ojanen, K. Lähdesmäki, and K. Salminen. 2005. "Development of an Improved Model for Mould Growth: Modelling." 
